Florida International University FIU Digital Commons

6-11-2013

\title{
Correlations among Coping Skills and Life Satisfaction in Ethnic Older Caregivers
}

Didiana de la Osa

Florida International University, didiana.delaosa@yahoo.com

DOI: $10.25148 /$ etd.FI13080510

Follow this and additional works at: https://digitalcommons.fiu.edu/etd

Part of the Psychology Commons

\section{Recommended Citation}

de la Osa, Didiana, "Correlations among Coping Skills and Life Satisfaction in Ethnic Older Caregivers" (2013). FIU Electronic Theses and Dissertations. 899.

https://digitalcommons.fiu.edu/etd/899

This work is brought to you for free and open access by the University Graduate School at FIU Digital Commons. It has been accepted for inclusion in FIU Electronic Theses and Dissertations by an authorized administrator of FIU Digital Commons. For more information, please contact dcc@fiu.edu. 


\title{
FLORIDA INTERNATIONAL UNIVERSITY
}

Miami, Florida

\section{CORRELATIONS AMONG COPING SKILLS AND LIFE SATISFACTION IN ETHNIC OLDER CAREGIVERS}

\author{
A thesis submitted in partial fulfillment of the \\ requirements for the degree of \\ MASTER OF SCIENCE \\ in \\ PSYCHOLOGY
}

by

Didiana de la Osa

2013 
To: Dean Kenneth G. Furton

College of Arts and Sciences

This thesis, written by Didiana de la Osa, and entitled Correlations among Coping Skills and Life Satisfaction in Ethnic Older Caregivers, having been approved in respect to style and intellectual content, is referred to you for judgment.

We have read this thesis and recommend that it be approved.

Dionne Stephens

Lisa Arango

Mary Levitt

Leslie Frazier, Major Professor

Date of Defense: June 11, 2013

The thesis of Didiana de la Osa is approved.

Dean Kenneth G. Furton

College of Arts and Sciences

Dean Lakshmi N. Reddi

University Graduate School

Florida International University, 2013 


\title{
ABSTRACT OF THE THESIS \\ CORRELATIONS AMONG COPING SKILLS AND LIFE SATISFACTION IN ETHNIC OLDER CAREGIVERS
}

\author{
by \\ Didiana de la Osa \\ Florida International University, 2013 \\ Miami, Florida

\section{Professor Leslie Frazier, Major Professor}

The purpose of the present study is to extend our current understanding of the effects of caregiver burden on life satisfaction by examining whether or not there are ethnic differences in coping strategies used to manage caregiving. Several specific hypotheses were tested in order to determine the linkages among age, gender, ethnicity (i.e., familism, filial piety), caregiver burden, coping with caregiving, and life satisfaction. A total of 103 Hispanic and Non-Hispanic White participants ages 60 and older were included in this study (mean age was $67.42 ; 16.5 \%$ male; $83.5 \%$ female; 52.4\% Hispanic; 47.6\% Non-Hispanic White). The results suggest that demographics and certain coping skills can influence levels of life satisfaction and burden experienced by caregivers. The findings from this study shed light on how to structure effective psychoeducational interventions, facilitate adaptive coping, reduce burden, and improve life satisfaction for older adult caregivers. 


\section{TABLE OF CONTENTS}

CHAPTER

PAGE

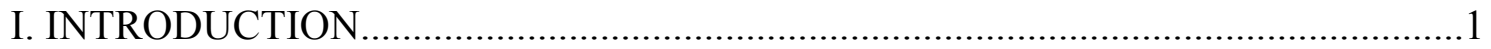

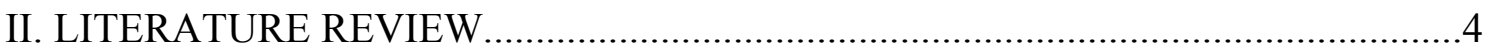

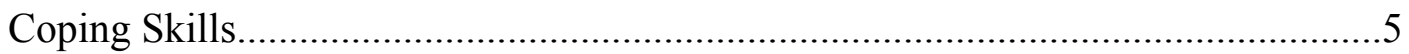

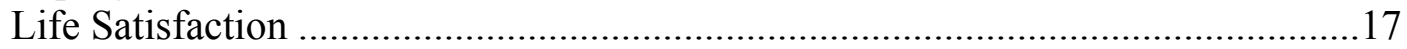

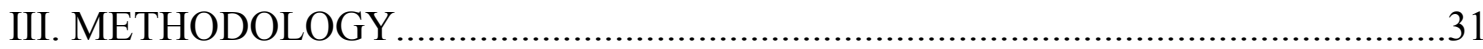

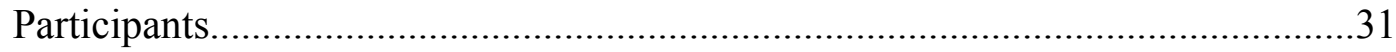

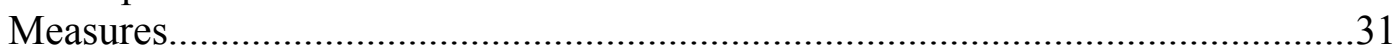

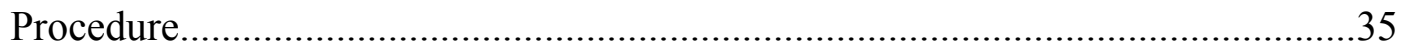

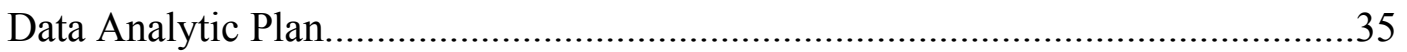

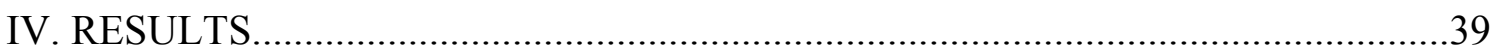

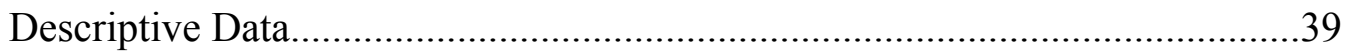

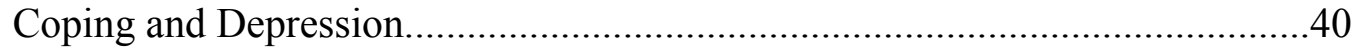

Demographic Differences in Burden.............................................................4

Demographic Differences in Coping...............................................................45

Demographic Differences in Life Satisfaction..................................................50

The Role of Familism and Filial Piety.............................................................51

Coping as a Moderator for Demographics and Life Satisfaction........................52

Coping as a Moderator for Burden and Life Satisfaction....................................55

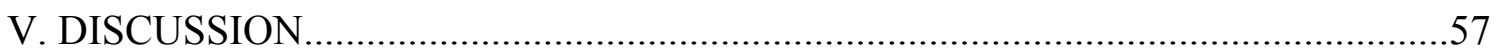

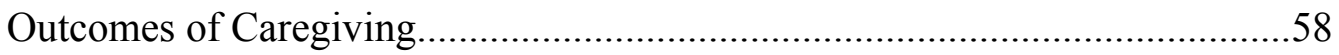

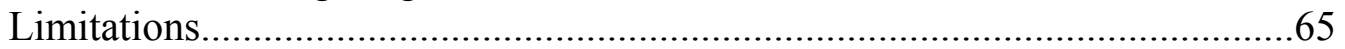

Potential Implications..............................................................................66

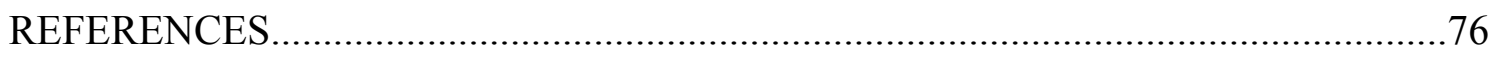

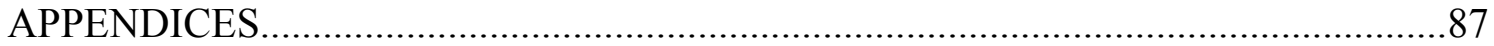




\section{CHAPTER I}

\section{Introduction}

The interaction between ethnicity, caregiver burden, and coping styles in the elderly is a multidimensional and elaborate issue that is still not well understood. However, it is imperative that the interactions among these variables be investigated because the aging population in the United States is increasing in diversity which may impact what we know about effective coping for late life issues such as caregiving. The influences of psychological and sociocultural factors on the coping skills that caregivers employ has been explored (Campbell, Converse, \& Rodgers, 1976; Chakrabarti \& Gill, 2002; Hooker, Frazier, \& Monahan, 1994; Lewinsohn, Redner, \& Seeley, 1991; Shimazu, Shimazu, \& Odara, 2005). More specifically, the role of personality (Chakrabarti, et al., 2002; Hooker, et al., 1994; Hooker, Monahan, Bowman, Frazier, \& Shifren, 1998; Lewinsohn, et al., 1991), culture (Caspi \& Elder, 1986; Greer \& Brown, 2011; Greer \& Chwalisz, 2007; Outten, et al., 2009; Utsey, Ponterotto, Reynolds, \& Cancelli, 2000), relationship with care-recipient (Lawrence, Tennstedt, \& Assman, 1998; McClendon, Smyth, \& Neundorfer, 2004; Quayhagen \& Quayhagen, 1988), economic status (Borg \& Hallberg, 2006; Jang, Chiriboga, Kim, \& Phillips, 2008; Rice, Near \& Hunt, 1980), role strain (Barusch \& Spaid, 1991; Bonebright, Clay, \& Ankenmann, 2000; Choo, Low, Karina, Poi, Ebenezer, \& Prince, 2003; Collins \& Jones, 1997), as well as occupational stress (Bonebright, Clay, \& Ankenmann, 2000; Gueritalt-Chalvin, Kalichman, Demi, \& Peterson, 2000), and gender (Collins, et al., 1997; Hooker, Manoogian-O’Dell, Monahan, Frazier, \& Shifren, 2000; Kristensson Ekwall \& Rahm Hallberg, 2006) have all been shown to increase the experience of stress (Collins, et al., 1997; Gueritalt-Chalvin, et al., 
2000; Hooker, et al., 1998), decrease life satisfaction (Arango-Lasprilla, Olivera Plaza, Drew, Perdomo Romero, Arango Pizarro, Francis, \& Kreutzer, 2010; Borg, et al., 2006; Haley, LaMonde, Han, Burton, \& Schonwetter, 2003), influence depression (Chang, Noonan, \& Tennstedt, 1998; Collins, et al., 1997; Haley, et al., 2003; Hooker, et al., 1998; Lawrence, et al., 1998), and increase co-morbid conditions in caregivers (Hooker, et al., 1998; Haley, et al., 2003; Lazarus \& Folkman, 1984). The proposed study intends to expand on previous research focusing specifically on how the burden of caregiving affects life satisfaction in an ethnically diverse sample of older adults. The mediational role of coping will be investigated in varied ethnic groups to examine its impact on outcomes of caregiver satisfaction beyond the known effects of demographics, such as gender and age. The knowledge of preferred coping styles in ethnic older caregivers is necessary to better understand the relationship between caregiving and life satisfaction in this population.

The present study aims to investigate the influence that demographic variables, such as age, gender, ethnicity, and caregiver burden, may have on the evaluation of aging caregivers' life satisfaction. Elderly female caregivers are expected to experience lower levels of life satisfaction than their male counterparts as a consequence of their more frequent use of ineffective coping strategies, such as escape and avoidance, (Lutzky \& Knight, 1994; Matud, 2004; Ptacek, Smith, \& Dodge, 1994), which have been shown to increase levels of distress (McClendon, et al., 2004). Furthermore, being of a certain ethnicity may have an effect on the coping strategies employed by caregivers in this study. Employing maladaptive coping strategies can exacerbate caregiver stress and, in turn, lower life satisfaction. Knowing what resources are more successful among certain 
ethnicities can aid efforts of intervention and ultimately improve their satisfaction with life. 


\section{CHAPTER II}

\section{Literature Review}

\section{Coping Skills}

The literature on stress and coping has grown extensively over the last 30 years. Yet, to date the most widely accepted theory of the stress and coping process is that of R. Lazarus and S. Folkman, (1984). The Transactional Theory of Stress and Coping (Lazarus \& Folkman, 1984), articulates the process of stress and coping as a result of how individuals interact with their environment (Folkman \& Lazarus, 1980). The first phase of coping with stress is known as the primary appraisal process, in which the individual determines whether the stressor presents a threat or challenge (Lazarus \& Folkman, 1984). How the stressor is assessed determines how the individual reacts on cognitive, physical, and psychological levels. The primary appraisal process also influences the next phase, the secondary appraisal process (Lazarus \& Folkman, 1984). Secondary appraisal is a cognitive evaluation of whether or not the resources in the individual's reservoir are sufficient to manage the stressor (Lazarus \& Folkman, 1984). The secondary appraisal process can mediate the primary appraisal process and is critical in deciding the effects of the stressor and the coping strategies used to manage it (Lazarus \& Folkman, 1984). To summarize, the Transactional Model of Stress suggests that when an individual experiences an event it is immediately appraised in terms of the effects of the stressor, simultaneously and in conjunction with the primary appraisal process, a secondary appraisal process determines how the individual will cope with the stressor. Both processes are integral to adjustment to the stressor. 
According to Lazarus \& Folkman, (1984), individuals may engage in a variety of coping strategies to manage immediate and chronic stress. Coping is conceptualized as the thoughts and actions; or emotions, cognitions, and behaviors, which an individual engages in to reduce, ameliorate, or adjust to the stressor. There are a wide array of behavioral responses individuals engage in to manage distress, from self-blame, positive reappraisal, action-oriented strategies, to strategies such as turning to religion, substance use, and seeking social support (Carver, 1997; Chakrabarti \& Gill, 2002). However, Lazarus \& Folkman, (1984), and others (Chakrabarti \& Gill, 2002; Folkman, 1984) have stated that these strategies can be divided into two conceptually different forms of coping. One form entails active and effortful strategies designed to control, change or eliminate the stressor, known as problem-focused coping (Folkman \& Lazarus, 1980). The second form of coping focuses on managing emotions and reactions brought about by the stressor, know as emotional-focused coping (Folkman \& Lazarus, 1980).

Research abounds on problem-focused and emotion-focused coping (Carver, 1997; Cheng, 2001; Cheng \& Cheung, 2005; Folkman \& Lazarus, 1980; Lazarus \& Folkman, 1984). In addition, a large body of research exists exploring the coping strategies of spousal caregivers of Alzheimer's or Parkinson's disease patients (Choo, et al., 2003; Hooker, et al., 1994; Hooker, et al., 2000; McClendon, et al., 2004; Morano, 2003). Studies show that people, in general, use a combination of both problem-focused and emotion-focused coping strategies in order to deal with the stressors they encounter (Cheng, 2001; Cheng, et al., 2005; Folkman \& Lazarus, 1980). Indeed the flexible use of coping styles has been found to be more effective in reducing the negative impact a stressor may have on an individual (Cheng, 2001; Frazier, 2000). However, simply 
because a person has a vast array of coping strategies does not ensure effective coping. Research has shown that those who successfully employ coping strategies do so, not by applying them in a random fashion, but rather by tailoring them to the particular stressor (Cheng, 2001; Frazier, 2000).

Measuring coping. To gain more conceptual clarity and more focused assessment of coping strategies some researchers have argued that assessing coping as a dispositional process as well as contextually sensitive process is more informative (Carver, Scheier, \& Weintraub, 1989). There are several measures available that assess both maladaptive and adaptive coping skills as well as problem-focused and emotionfocused coping strategies (Carver, 1997; Carver, et al., 1989; Endler \& Parker, 1990; Lazarus \& Folkman, 1984). Carver, et al., (1989), however, argue that distinguishing between the two kinds of coping is not sufficient. The authors posited that one may employ dispositional coping styles, defined as a preferred set of coping strategies used across circumstances, or contextually sensitive coping styles, where one utilizes coping methods tailored to the specific stressor. Thus, Carver, et al., (1989), created a theoretically driven measure of functional and non-functional coping. The instructions of the scale can be tailored to measure either dispositional or situational strategies of coping

The COPE consists of 15 sub-scales that measure different coping strategies: Active Coping, Planning, Suppression of Competing Activities, Restraint Coping, Seeking Social Support for Instrumental Reasons, Seeking Social Support for Emotional Reasons, Focusing on Venting of Emotions, Behavioral Disengagement, Mental Disengagement, Positive Reinterpretation and Growth, Denial, Acceptance, Humor, Substance Abuse, and Turning to Religion (Carver, et al., 1989). Active coping is 
defined as the participants' efforts to actively remove the stressor from their lives, while the use of Planning is related to cognitions employed to aide in coping with the stressor. In addition, Suppression of Competing Activities entails putting other projects aside to better handle the stressor, so as not to distract oneself or occupy one's time on other activities. Moreover, Restraint coping reflects holding back and not acting prematurely in order to effectively deal with the stressor. Using Emotional Support is defined as seeking sympathy, moral support, or compassion, whereas Using Instrumental Support is seen as seeking advice or assistance. Venting of emotions is described as the tendency to focus on the stressor and the distress it causes and express those emotions, while Behavioral Disengagement is said to be the actions taken to avoid the stressor and to reduce the effort employed in dealing with the stressor. Mental disengagement is said to occur when behavioral disengagement fails and entails mentally distracting one's self from the stressor or efforts used to cope with it. Positive reinterpretation is a coping strategy aimed at managing the distress caused by a stressor, rather than the stressor itself. Furthermore, Denial is a form of appraisal that diminishes perceived distress caused by the stressor. Conversely, Acceptance is said to be a functional coping skill in which the person accepts the reality of a stressor and accommodates it into their lives. Humor is coping strategy used to make light of the situation, while Substance Use is a coping skill used in order to disengage oneself from the stressor. Finally, Turning to religion might serve as a source of emotional support, may help positive reappraisal take place, or may be a method of active coping (Carver, et al., 1989).

Aging and coping. Differences in coping styles across age groups have been documented in the literature (Aldwin, Sutton, Chiara, \& Spiro, 1996; Brändtstadter \& 
Renner, 1990; Brändtstadter, Rothermund, \& Schmitz, 1997; Brändtstadter, Wentura, \& Greve, 1993; Folkman, Lazarus, Pimley, \& Novacek, 1987). Research has found that the elderly tend to use more passive coping strategies, such as acceptance, compared to their younger counterparts (Birkeland \& Natvig, 2009; Folkman, et al., 1987), which is unfortunate since proactive measures of coping have been found to improve functional ability and independence in everyday activities among the elderly (Fiksenbaum, Greenglass, \& Eaton, 2006). These discrepancies in coping styles remained stable and consistent even when the different age groups were coping with similar stressors (Folkman, et al., 1987). In addition, those in the older age groups were less likely to use escapism, hostility and instrumental methods as coping mechanisms (Aldwin, et al., 1996). However, the results of the coping resources employed were not found to differ between younger participants, middle-aged participants and the elderly participants (Aldwin, et al., 1996; Hamarat, Thompson, Steele, Matheny, \& Simons, 2002). Thus, although coping strategies vary by age groups, with the elderly using more passive methods, there exist comparable outcomes across age groups in the effectiveness of coping strategies employed in handling perceived stressors.

Some researchers suggest that differences in coping across age groups are a sign of adaptive flexibility in coping (Brändtstadter, et al., 1990; Brändtstadter, et al., 1997; Brändtstadter, et al., 1993). Active measures of coping to achieve goals in youth are beneficial and preferable, however, more accepting or accommodating methods of coping assist in adapting to the deterioration and losses faced in old age, allowing the elderly to maintain their satisfaction with life even in the face of disability (Brändtstadter, et al., 1990; Brändtstadter, et al., 1997; Brändtstadter, et al., 1993). Agren, (1998), found that 
the oldest of old cope with challenges by redirecting their focus away from activities which are difficult to engage in due to functional disabilities and toward those activities that are still feasible. The use of adaptive and flexible coping may explain why some researchers find no differences in life satisfaction across age groups (Hamarat, et al., 2002).

However, the role of aging can add a significant amount of stress to those engaging in caregiving tasks in later life (Roberto, 1995). Physical deterioration, illness, functional disability, and lack of patience can pose a hindrance to caregivers. Indeed, caregivers have been shown to perceive aging as adversely affecting their functionality (Minnes, Woodford, \& Passey, 2007). Research has shown that although they are faced with additional stressors, aging caregivers are more reluctant to seek out services and help to share the responsibilities of caregiving tasks than younger caregivers (Hayden \& Heller, 1997). Furthermore, problem-focused coping strategies, such as problem-solving and planning are said to reduce burden and actually bring about positive gains in the specific subset of the elderly caregivers (Ribeiro \& Paul, 2008). As a result of the previously mentioned patterns of coping employed by the elderly, this can put aging caregivers at a disadvantage in coping with their caregiving roles.

Caregiver burden and coping with caregiving. Caregiving is stressful and has an impact on caregivers' mental health. Being a caregiver has been correlated with melancholy mood, social isolation, family conflict, drug and alcohol use, poor health, and impaired immune system functioning (Choo, et al., 2003). Caregivers with high levels of stress are at greater risk for abusive or neglectful behavior towards those receiving their care, perhaps because they lack effective channels through which to express their 
emotional distress. Moreover, variables related to patient and caregiver characteristics can interact to affect caregiver burden (Choo, et al., 2003). In the patient, factors such as behavior problems, functional impairment and severity, and chronicity of illness may lead to increases in caregiver burden experienced. Caregiver variables such as age, education level, health status, social support and relationship with the care receiver impact level of burden as well. Research has shown that these influences are more pronounced in elderly female caregivers (Choo, et al., 2003). The influence of ethnicity has also been shown to play an important role in how caregivers handle their roles (Choo, et al., 2003). More expansive social networks may reduce caregiver burden by diffusing the responsibilities of caregiving tasks and reducing feelings of isolation associated with the caregiving role (Guarnaccia \& Parra, 1996). However, some research states that ethnic caregivers may not feel they receive enough social support (Haley, et al., 1996). Moreover, assistance in the caregiving role has been correlated with lower levels of burden, however, paid help did not alleviate stress (Guarnaccia, et al., 1996; McCabe, Yeh, Lau, Garland, \& Hough, 2003).

Spousal caregivers have been found to experience greater burden than other subsets of caregivers (George \& Gwyther, 1986; Neal, Ingerson-Dayton, \& Starrels, 1997; Schulz, O’Brien, Bookwala, \& Fleissner, 1995). Wives have been shown to experience more distress than husbands when taking care of a disabled spouse. Conversely, husband caregivers have actually reported an improvement in the relationship with their wives after they became caregivers (Fitting, Rabins, Lucas, \& Eastham, 1986). Female spousal caregivers felt the greatest reward when they felt companionship from their husbands (Raschick \& Ingersoll-Dayton, 2004), which is the 
case in some disease contexts such as Parkinson's Disease, but not in the cases of other disease contests, such as Alzheimer's disease (Hooker, et al., 2000). Adult sons caring for their parents also experience improvement in the relationship and experience higher levels of gratification than spousal caregivers (Hinrichsen, Hernandez, \& Pollack, 1992). Hinrchsen, et al. (1992), postulate this may be a consequence of adult children caregivers perceiving their caregiving responsibilities as an opportunity to return the nurturance their parents offered them.

Social support has been shown to reduce the impact of burden on caregivers of patients with psychosis (Grandon, al., 2008; Quayhagen, et al., 1988). In fact, as much as $5 \%$ of such burden is attributed to lack of social/affective support (Grandon, al., 2008). In addition, emotional over involvement may lead to heightened levels of distress and burden when caregivers feel the care receiver's symptoms are out of one's control. It has also been found that emotion-focused methods of coping are less effective in alleviating perceived burden than problem-focused methods (Kristensson Ekwall \& Rahm Hallberg, 2006; McClendon, et al., 2004) and may actually increase the levels of stress suffered (Grandon, et al., 2008). Paradoxically, emotion-focused coping strategies are the most commonly used among caregivers with lower levels of burden (Chakrabarti, et al., 2002). However, higher levels of perceived stress prompted the use of problem-focused coping strategies (Chakrabarti, et al., 2002).

Research shows that successful interventions for caregivers included improving reframing skills, problem solving skills and seeking social support (McClendon, et al., 2004; Quayhagen, et al., 1988). Acceptance was found to reduce depression, increase positive affect and reduce any negative symptoms. The previously mentioned coping 
skills were also linked to longer survival time for care recipients (McClendon, et al., 2004). Wishfulness and fantasy were found to be correlated with poor mental health, leading to greater depression and anxiety and. Similarly, escape and distancing were found to increase emotional distress (McClendon, et al., 2004).

Thus, the experience of caregiver burden is best described as the adverse effects caregiving responsibilities have on one's physical and emotional health, social life, and financial status (Zarit, Reever, \& Bach-Peterson, 1980). Moreover, the experience of caregiver burden may be influenced by factors, such as demographics and culture (Choo, et al., 2003), relationship with the care recipient (George, et al., 1986; Hinrichsen, et al., 1992; Neal, et al., 1997; Raschick, et al., 2004; Schulz et al., 1995) and coping strategies employed (Grandon, et al., 2008; Kristensson Ekwall, et al., 2006, McClendon, et al., 2004; Quayhagen, et al., 1988). Caregivers who use more emotion-focused coping strategies have been known to fare worse than those who employ problem-focused coping methods (Baker \& Robertson, 2008; McClendon, et al., 2004; Quayhagen, et al., 1988; Rose, Strauss, Neundorfer, Smyth, \& Stuckey, 1997; Saad, et al., 1995).

Acceptance is an exception to the negative effect emotion-focused coping strategies have on caregivers since use of this specific coping method has led to decreased levels of burden (Baker et al., 2008; Rose, et al., 1997; Saad, et al., 1995).

Gender and coping. Men and women have been found to use different coping strategies when faced with stressors (Folkman, et al., 1980; Lutzky, et al., 1994; Matud, 2004; Ptacek, et al., 1994; Tamres, Janicki, \& Hegelson, 2002; Yeh, Huang, Chou, \& Wan, 2009). Although the differences are minor, women utilize more emotion-focused coping styles (Endler \& Parker, 1990), such as avoidance (Lutzky, et al., 1994; Matud, 
2004; Ptacek, et al., 1994) and seeking social support (Lutzky, et al., 1994; Ptacek, et al., 1994; Tamres, et al., 2002; Yeh, et al., 2009). Men, on the other hand, have been shown to employ more problem-focused coping styles when facing stressors (Endler \& Parker, 1990; Folkman \& Lazarus, 1980; Ptacek, et al., 1994). Although both sexes use a combination of emotion-focused and problem-focused coping strategies, men are somewhat more likely to utilize instrumental methods of coping with a stressor (Ptacek, et al., 1994).

A preference for certain coping strategies is also seen across genders in caregivers (Navaie-Waliser, Spriggs, \& Feldman, 2002). Female caregivers were more likely than their male counterparts to engage in emotion-focused coping strategies, such as turning to religion (Navaie-Waliser, et al., 2002) and wishful thinking (Rose, et al., 1997). In addition, female caregivers were more likely than male caregivers to reallocate time from other activities, such as employment and leisure, to caregiving tasks (Navaie-Waliser, et al., 2002), which may be detrimental since these actions could lead to social isolation and financial strain. In fact, the tendency to forego employment and social activities may provide some explanation as to why women report more difficulties than men in caregiving (Navaie-Waliser, et al., 2002) as well as higher levels of distress (Adams, Aranda, Kemp, \& Takagi, 2002; Navaie-Waliser, et al., 2002).

However, the literature shows that male caregivers who employ more emotionfocused strategies, with the exception of acceptance, report levels of distress similar to female caregivers (Rose, et al., 1997). Similarly, female caregivers who employed more problem-focused coping skills experienced less depression and caregiver burden (Essex, Seltzer, \& Krauss, 1999). Rose, et al., (1997), reported that although there are 
differences in coping styles across genders, distress may be a function of the coping strategies used by the caregiver, rather than a result of gender.

Ethnicity and coping. Like gender, ethnicity may be differentially associated with caregiver burden and caregiver coping. However, there appears to be a lack of consensus in the literature concerning disparities between coping strategies used by nonHispanic Whites and other ethnicities. Some research suggests that the coping styles employed are similar across ethnicities (Barber, 2002; McCallum, Longmire, \& Knight, 2007), while other studies report there indeed exist discrepancies (Knight \& McCallum, 1998; Kosberg, Kaufman, Burgio, Leeper, \& Sun, 2007; Pinquart \& Sorensen, 2005; Sun, Kosberg, Leeper, Kaufman, \& Burgio, 2010). Researchers who have found variations in coping styles suggest certain ethnic groups have higher rates of using emotion-focused coping than non-Hispanic Whites (Knight, et al., 1998; Kosberg, et al., 2007; Pinquart, et al., 2005; Sun, et al., 2010; Trail Ross, \& Aday, 2006; Wykle, \& Segall, 1991). NonHispanic Whites have been found to seek assistance from support groups and receive other forms of help from mental health professionals more often than other ethnicities (Montoro-Rodriguez, \& Gallagher-Thompson, 2009).

Caregivers who identify as African American have been shown to use different coping styles than Non-Hispanic White caregivers (Knight, et al., 1998; Kosberg, et al., 2007; Pinquart, et al., 2005; Sun, et al., 2010; Trail Ross, et al., 2006; Wykle, et al., 1991). One of the coping methods used more frequently by this group is the use of religion (Haley, et al., 1996; Kosberg, et al., 2007; Pinquart, et al., 2005; Sun, et al., 2010; Wykle, et al., 1991). For this population, religion acts as a window to access spiritual comfort and emotional support from the congregation (Sun, et al., 2010). In 
fact, African American caregivers have been found to turn to religiosity more so than both Hispanic and Non-Hispanic White caregivers (Morano, \& King, 2005), which is beneficial since higher levels of religiosity has been shown to lower levels of distress. Social support is another coping strategy seen more frequently in African Americans than in non-Hispanic Whites (Pinquart, et al., 2005; Wykle, et al., 1991). Not only was this group more likely to receive more social contact from others, but they also reported more informal support in their caregiving tasks (Pinquart, et al., 2005). For many African American caregivers, the caregiving role was shared with others and responsibilities of the caregiver were dispersed. Avoidance of the stressors and positive reappraisal of the caregiving role as a rewarding experience were also strategies common among African American caregivers (McCallum, et al., 2007; Pinquart, et al., 2005; Trail Ross, et al., 2006).

Another ethnic difference in coping is that, Hispanic caregivers tend to engage in active coping less than Non-Hispanic White caregivers (Montoro-Rodriguez, et al., 2009; Pinquart, et al., 2005). Female Hispanics have been shown to engage in avoidance and escape coping strategies in order to handle the stress of the caregiver role (MontoroRodriguez, et al., 2009; Sander, et al., 2007). However, Hispanics as a group report acceptance of the caregiver role and its responsibilities more frequently than their NonHispanic White counterparts (Sander, et al., 2007). Informal support from loved ones in which caregiving tasks are shared (Cox, \& Monk, 1990; Pinquart, et al., 2005) and religious coping which provides comfort and another avenue for social contact and support (Navaie-Waliser, et al., 2001) were also used by Hispanics in efforts to alleviate the stress of caregiving. 
Interestingly, Asian caregivers also engage in more emotion-focused coping strategies than Non-Hispanic White caregivers (Pinquart, et al., 2005). Research has shown that Asians relied heavily on informal support with the caregiving responsibilities much like African Americans and Hispanics did and were the ethnic group least likely to turn to formal caregiving, such as paid help (Kim \& Knight, 2008, Pinquart, et al., 2005). Asian caregivers also engaged in cognitive coping strategies (Kim, et al., 2008) to buffer the impact of caregiving stressors, such as avoidance and distancing themselves from the stressors (Lee \& Sung, 1998).

Variables that affect coping. Taken together, research has shown that demographic factors such as age, gender, and ethnicity can influence both the primary and secondary appraisal process described in the Transactional Theory of Stress and Coping. The impact these variables have on the primary appraisal process is demonstrated by group differences in evaluations of caregiving. Women tend to report less rewards from caregiving responsibilities than men (Fitting, et al., 1986; Hinrichsen, et al., 1992). Because of their own functional decline, the elderly tend to view caregiving as more burdensome than younger caregivers (Minnes, et al., 2007). In addition, African Americans, Hispanics, and Asians view their caregiving roles as a normative experience which they do not have to endure alone (Guarnaccia \& Parra, 1996).

The secondary appraisal process is also influenced by the demographic variables mentioned previously. Women have been shown to employ more emotion-focused methods of coping, such as using religion or wishful thinking (Navaie-Waliser, et al., 2002; Rose, et al., 1997) than male caregivers. Furthermore, aging caregivers use more passive methods of coping than their younger counterparts (Hayden \& Heller, 1997). 
Similarly, certain ethnicities tend to employ emotion-focused coping strategies, such as turning to religion and avoidance to handle the effects of caregiving, more so than NonHispanic Whites (Knight, et al., 1998; Kosberg, et al., 2007; Pinquart, et al., 2005; Sun, et al., 2010; Trail Ross, et al., 2006; Wykle, et al., 1991). The above mentioned influences of demographic variables on coping strategies used by caregivers are a focus of this study. The impact of gender and ethnicity on coping styles employed by elderly caregivers will be examined.

\section{Life satisfaction}

Life satisfaction is important within the context of caregiving because it is affected by the particular burden of caregiving as well as the efficacy of coping. Life satisfaction can be conceptualized as the happiness and contentment one feels in his or her life as an overall synthesis of the many individual domains that compromise one's life (Lewinsohn, et al., 1991). However, it is not merely an emotional state, but an evaluative process in which life is assessed in the context of subjective criteria, such as what constitutes success (Caspi \& Elder, 1986; Diener, Emmons, Larsen, \& Griffin, 1985;

Lewinsohn, et al., 1991; Mallard, Lance, \& Michalos, 1997; Meadow, et al., 1992; Michalos, 1986). Life satisfaction as an evaluative process is a dynamic and multifaceted assessment of the overall conditions of one's life (Caspi et al., 1986; Diener, 1984; Mallard, et al., 1997; Michalos, 1986).

Findings show that elevated life satisfaction has been linked to general well being and positive effects on mood and emotions (Pasupuleti, Allen, Lambert, \& Cluse-Tolar, 2009). Those with high levels of life satisfaction report higher self-esteem and feeling good about their lives (Lewinsohn, et al., 1991). They tend to be happier and have more 
social and cultural interactions (Griffin \& McKenna, 1998). There is also a propensity to be more efficient and productive in handling problems that may arise in the workplace as well as demonstrating more creativity and open-mindedness (Pasupuleti, et al., 2009).

Measuring life satisfaction. Life satisfaction, because it is the self-reported outcome of a highly subjective evaluative process, can be difficult to measure (Caspi \& Elder, 1986; Diener, Emmons, Larsen, \& Griffin, 1985; Lewinsohn, et al., 1991; Mallard, Lance, \& Michalos, 1997; Meadow, et al., 1992; Michalos, 1986). In the present study, life satisfaction is conceptualized in accordance with Multiple Discrepancies Theory (MDT) which states that net satisfaction is a result of the divergence between one's current state and one's ideal state (Michalos, 1986). Specifically, satisfaction is "a linear function of the discrepancy between what one has and 1) what one wants, 2) what others have, 3) the best one has had in the past, 4) what one expected to have three years ago, 5) what one expects to have in five years, 6) what one deserves, and 7) what one needs" (Mallard, et al., 1997, p . 260; Michalos, 1986). Given that certain comparisons are made between one's current state and one's ideal state, the congruence of these determine the levels of satisfaction one experiences (Mallard, Lance, \& Michalos, 1997; Meadow, et al., 1992; Michalos, 1986). That is, if one feels that they currently have what they desire, that it is as good as what others have and what they have had in the past, and that they want to maintain it in the future, they will have increased life satisfaction. Since caregiving is a situation that creates stress, it is likely that life satisfaction may be compromised because it may exacerbate discrepancies in the previously mentioned domains. 
Furthermore, life satisfaction is influenced by Top Down (TD), Bottom Up (BU) or Bidirectional processing (BD) (Diener, 1984; Deiner, Suh, Lucas, \& Smith, 1999; Mallard, et al., 1997). Top Down processing states one has a propensity to experience things positively or negatively and this influences interactions one engages in (Diener, 1984; Mallard, et al., 1997). Proponents of the TD perspective argue personality traits, such as high self-esteem (Campbell, et al., 1976), and sociability (Diener, 1984), have a positive impact on assessment and perception of life and one's satisfaction with it. The TD framework proposes overall life satisfaction influences satisfaction in individual life facets or sub-domains (Diener, 1984; Mallard, et al., 1997). In contrast, BU processing suggests external events and demographics, such as age, marriage, standard of living, work, school and leisure activities, have a direct effect on life satisfaction (Diener, 1984; Deiner, et al., 1999; Mallard, et al., 1997). The BU processing model conceptualizes overall satisfaction to be a result of the combination of satisfaction experienced in individual domains of one's life. A BD view of overall life satisfaction posits that the influence of both BU and TD processes are present in one's evaluation of life satisfaction (Gerhart, 1987; Mallard, et al., 1997). In this view, both satisfaction in individual aspects of life and the personality traits one expresses interact to influence the assessment of one's happiness.

Bottom Up processing was chosen in the present study to conceptualize life satisfaction because it considers demographics and the assessment of and satisfaction with life facets, such as participants age, gender, ethnicity, level of caregiver burden, and appraisal of the caregiving role, and how all these sub-domains come together to form an experience of overall life satisfaction (Diener, 1984; Diener, et al., 1999; Mallard, et al., 
1997). BU processing fits well with another model used here to conceptualize life satisfaction, MDT, which states that perceptions of discrepancies between one's present state and one's ideal state in life domains, such as the one's suggested by the BU processing model, and with life as a whole influence the experience of overall satisfaction (Mallard, et al., 1997; Michalos, 1986). Therefore, in the present study life satisfaction will be determined by the participant's assessment of the degree of closeness between their present state and ideal state, their evaluation of condition of their lives, as well as their report of subjective satisfaction. The degree to which the participants feel they have accomplished important goals in their lives and the desire to change aspects of their lives will also be used to assess their degree of life satisfaction.

Caregivers and life satisfaction. There is a large body of literature which shows that life satisfaction is affected negatively by the caregiver role (Arango-Lasprilla, et al., 2010; Borg \& Hallberg, 2006; Haley, et al., 1996; Haley, et al., 2003). Lawton, Moss, Kleban, Glicksman, and Rovine (1991), proposed a two-factor model which argues that caregiving can be both a source of satisfaction as well as exhaustion. The authors argue that the commitment to caring for someone can be a positive and fulfilling experience, but may also be a burden at times because of role strain the depletion of caregiver's resources (Borg, et al., 2006; Lawton, et al., 1991; Morano, 2003). Satisfaction with caregiving responsibilities has been correlated with increased positive affect but has not been shown to efficiently alleviate burden or negative affect (Lawton, et al., 1991; Wilson-Genderson, Pruchno, \& Cartwright, 2009). In addition, caregiver burden has been correlated with negative affect and has been known to reduce positive affect (Lawton, et al., 1991; Wilson-Genderson, et al., 2009). 
Haley, et al., (2003) present the Stress Process Model which specifies variables which affect caregiver outcomes. These variables include primary stressors, those directly related to caregiving, and secondary stressors, such as poor health (Haley, et al., 2003). Protective factors are also described in The Stress Process Model. These include positive appraisals of the caregiving situation, adaptive coping responses, and positive social interactions (Haley, et al., 2003). These factors work together to impact the levels of depression and life satisfaction felt by caregivers. Those with higher levels of negative appraisal of caregiver duties and ineffective coping tend to experience increased depression and lowered life satisfaction (Haley, et al., 2003).

According to the Stress-Process Model, one factor that has a buffering effect on life satisfaction is the relationship the caregiver shares with the care recipient (Lawrence, et al., 1998). The quality of the relationship can mediate the effect problem behaviors have on the caregiver's levels of depression and life satisfaction (Lawrence, et al., 1998). When problem behaviors occur, the relationship between the caregiver and the carerecipient suffers, which may lead the caregiver to experience elevated levels of depression and a decreased experience of life satisfaction (Lawrence, et al., 1998). The relationship may also serve as a moderator in this interaction. When the quality of the relationship was high, caregivers experienced higher levels of distress when the care receiver deteriorated and functional ability declined (Lawrence, et al., 1998).

Haley, et al., (2003) applied the Stress-Process Model in a study that examined risk factors and protective factors in caregivers and how these factors predicted depression and life satisfaction. The authors found that objective caregiver strains, such as duration of caregiving, or severity of patient symptoms, were only moderate predictors 
of the caregiver's levels of depression or life satisfaction. Other factors, however, were found to be better predictors of caregiver's state of being, for example negative social interactions were found to be correlated with higher ratings of depression (Haley, et al., 2003). Conversely, greater numbers of social interactions were caregivers felt content with the social support they received were correlated with a better state of being (Borg, et al., 2006; Haley, et al., 2003; Morano, 2003; Waldron-Perrine, et al., 2009) and good caregiver health was associated with greater life satisfaction (Haley, et al., 2003). Furthermore, the subjective appraisal a caregiver had of their required tasks, along with the benefits they felt were received from caregiving were also more closely associated with life satisfaction and depression than objective stressors (Haley, et al., 2003; Morano, 2003). Those who evaluated their responsibilities as less stressful and found caregiving to be rewarding and fulfilling reported higher life satisfaction and lower depression (Haley, et al., 2003).

Aging and life satisfaction. Beyond the effects of caregiver burden, the aging process may create an added burden to caregivers because of possible deterioration and reduction in functionality, thus impacting life satisfaction. Aging caregivers are at an increased risk for reduction in life satisfaction and increase in depression compared to noncaregivers (Haley, LaMonde, Han, Narramore, \& Schonwetter, 2001). The manner in which their caregiving tasks are appraised is a factor affecting the experience of caregivers, such that positive appraisals of the caregiving role and its rewards leads to greater life satisfaction and lower levels of depression (Haley, et al., 2003). Greater number of positive social activities and expansive social networks were also linked to greater levels of life satisfaction in aging caregivers (Haley, et al., 2003). Having a 
spouse to share financial burden and household responsibilities was also found to increase the life satisfaction experienced and alleviate caregiver burden among the elderly (Landry-Meyer, Gerard, \& Guzell, 2005).

Loneliness plagues many caregivers when social relationships are hindered (Borg, et al., 2006). As previously mentioned, social support has positive effects on life satisfaction and is correlated with higher levels of contentment (Borg, et al., 2006; Grandon, et al., 2008; Hooker, et al., 1998; Morano, 2003; Waldron-Perrine, et al. 2009). In fact, Borg, et al., (2006) reported that one third of the caregivers they surveyed wished they could spend more time engaging in social interactions. A smaller group reported having no one to speak to in a time of need, which may bring about issues of distress, such as isolation (Borg, et al., 2006).

It has also been reported that caregivers receive support only infrequently (Borg, et al., 2006). Their most sought after form of support is economic assistance and speaking to someone who is also in a caregiving position about their problems (Borg, et al., 2006). Caregivers who are gainfully employed received the latter from their coworkers (Borg, et al., 2006), which may explain why people in this category report higher life satisfaction. In addition, there is very little agreement between what a caregiver would like to receive as a form of support and what they actually obtain (Borg, et al., 2006).

Gender, caregiver burden, and life satisfaction. Independent of personality characteristics and subjective appraisals, men and women's life satisfaction has been reported to be affected by different objective factors (Waldron-Perrine, et al. 2009). In a study conducted by Waldron-Perrine, et al., (2009), the authors concluded that caregivers 
who receive inadequate social support are more likely to be negatively affected by the care recipient's duration of illness and severity of symptoms, particularly among women (Waldron-Perrine, et al. 2009). Caregiver income and uncertainty about the care recipient's prognosis, however, had an equal effect among both genders (WaldronPerrine, et al. 2009). Interestingly, the authors found that the relationship between the duration of the illness and life satisfaction was positively correlated for men and negatively correlated for women, which suggests that men begin to adapt to caregiving tasks over time, while women suffer from negative cumulative effects (Waldron-Perrine, et al. 2009).

Research shows that women are more negatively affected by caregiving responsibilities than men (Collins, et al., 1997; Hooker, et al., 2000; Kristensson Ekwall, et al., 2006; Waldron-Perrine, et al., 2009). Female caregivers have been shown to undergo more distress and strain when caring for others (Hooker, et al., 2000; WaldronPerrine, et al., 2009) while men giving care to a loved one report being satisfied with their lives (Kristensson Ekwall, et al., 2006). Caregiving tasks have not been found to cause this discrepancy between men and women's burden since both sexes engage in the same amount of workload associated with caregiving (Collins, et al., 1997). Women were reported to feel unable to cope with their situation more often and felt obligated to continue providing care even though they would prefer to discontinue caregiving (Collins, et al., 1997). Nevertheless, there still remains the belief that women are better suited to taking over the caregiver role and that women are better equipped to handle it (Collins, et al., 1997). 
Hooker, et al., (2000), found a clear difference in male and female caregivers. Women caring for their husbands suffering from dementia were found to have significantly worse mental health than husbands caring for their wives in the same group (Hooker, et al., 2000). In contrast, no differences in mental health were found between husband and wife caregivers in the group comprised of nondementia patients, even though the groups did not differ in their use of social support (Hooker, et al., 2000). The authors suggested that women fare worse than men in caregiving situations if cognitive deterioration is present.

Ethnicity and life satisfaction. As stated previously, the assessment and appraisal of caregiving and its responsibilities has an impact of the experience of life satisfaction and depression. For some ethnicities, this appraisal may be influenced by factors such as familism and filial piety (Kim, Knight, \& Flynn Longmire, 2007; McCallum, et al., 2007; Pinquart, et al., 2005). Familism is conceptualized as the "subordination of individual interests to those of the family" (Rogers \& Sebald, 1962, $p$. 26), and filial piety is the submission to one's elders which entails both emotional support as well as physical and financial assistance (Yeh \& Bedford, 2003). Indeed appraisal of caregiver burden may be impacted by familism (Kim, et al., 2007; McCallum, et al., 2007). Strong familism beliefs accompanied by positive social support may improve health outcomes in caregivers (McCallum, et al., 2007). Conversely, the idea of being obligated to care for someone because of filial piety may lead to powerlessness and decreased life satisfaction (Anngela-Cole \& Hilton, 2009). Ethnic groups in general reported the caregiving role to be more rewarding than Non-Hispanic White caregivers 
(Pinquart, et al., 2005). One explanation may be the influences of familism and filial piety.

Familism and positive filial beliefs are endorsed by African American caregivers, more so than Non-Hispanic White caregivers (McCallum, et al., 2007; Pinquart, et al., 2005). The endorsement of Familism and Filial Piety may have an impact on African American caregivers since they experience less depression and burden (Roth, Haley, Owen, Clay, \& Goode, 2001), and greater life satisfaction than Non-Hispanic White caregivers (Haley, et al., 1995; Lawton, Rajagopal, Brody, \& Kleban, 1992; Roth, et al., 2001). African Americans also reported greater reward and satisfaction obtained from the caregiver role (Lawton, et al., 1992) and experience less stress and feel more efficacious than Non-Hispanic White caregivers (Haley, Wadley, West, \& Vetzel, 1994).

Familism is also seen among Hispanic caregivers (Pinquart, et al., 2005).

Similarly to African Americans, Hispanic caregivers reported greater rewards and uplifts from caregiving (Pinquart, et al., 2005), and felt more competent in managing the caregiving role (Montoro-Rodriguez, et al., 2009) than Non-Hispanic White caregivers. However, they were found to experience more elevated levels of depression and distress than Non-Hispanic White caregivers (Pinquart, et al., 2005; Valle, Yamada, \& Barrio, 2004). In fact, Hispanics fared worse than both Non-Hispanic White (Adams, et al., 2002; Cox, et al., 1990; Valle, et al., 2004) and African American caregivers (Adams, et al., 2002; Cox, et al., 1990; Morano, et al., 2005) evidenced by significantly higher levels of depression and psychological distress experienced (Adams, et al., 2002; Cox, et al., 1990). Although both African Americans and Hispanics reported the use of religion and spirituality as a powerful coping mechanism to handle the demands of caregiving, this 
marked discrepancy may be because Hispanic caregivers felt they needed more social support (Adams, et al., 2002). Furthermore, the existence of familism beliefs without sufficient social support has been correlated with greater distress and caregiver burden (McCallum, et al., 2007).

Other ethnic groups may also experience caregiving differently from White NonHispanics due to their cultural beliefs. For example, Asian caregivers who engage in caregiving because of sense of obligation or filial piety were shown to experience less life satisfaction compared to those who did so because of a conscious choice to engage in caregiving (Anngela-Cole, et al., 2009). Specifically, Japanese caregivers were found more likely to care for their elders to avoid fear of social isolation or shame (Asai, 2002), which may affect their life satisfaction compared to other Asians in the caregiving role. Overall, Asian caregivers were found to report higher levels of depression and burden than their Non-Hispanic White counterparts (Pinquart, et al., 2005), which is problematic because Asian caregivers have at times lacked in services and outlets which reduce caregiver burden (Ho, Weitzman, Xingjia, \& Levkoff, 2000).

Thus, on the basis of the research presented, it appears as though many factors interact to culminate in the experience of caregivers' life satisfaction. Indeed, factors such as familism and filial piety (Kim, et al., 2007; McCallum, et al., 2007; Pinquart, et al., 2005) as well as the age (Haley, et al., 2001) and gender (Collins, et al., 1997; Hooker, et al., 2000; Kristensson Ekwall, et al., 2006; Waldron-Perrine, et al., 2009) of the caregiver impact the perception of the caregiver role. Caregivers' view of the caregiving role has been shown to influence the levels of caregiver burden (Anngela-Cole \& Hilton, 2009; Haley, et al., 2003; Kim, et al., 2007), which in turn affects the 
experience of life satisfaction (Asai, 200; Haley, et al., 2003). The quality of the relationship between the caregiver and care receiver also affects the experience of caregiver burden (Lawrence, et al., 1998) and resulting life satisfaction. Furthermore, it is suggested in the literature that adaptive coping skills can reduce levels of distress and caregiver burden resulting higher levels life satisfaction (Haley, et al., 2003).

The purpose of the present study is to extend our current understanding of the effects of caregiver burden on life satisfaction by examining whether or not there are ethnic differences in coping strategies used to cope with caregiving. There is a lot of compelling evidence of effective strategies for coping with caregiving for a spouse or loved-one with a chronic condition, such that caregiver burden is lessened and life satisfaction may be maintained. There is evidence that both gender and ethnicity may impact caregiver burden, ways of coping with the stress of caregiving, and ultimately life satisfaction. It is also clear from the literature that there are ethnic and cultural differences in the methods and efficacy of coping with stress, and in particular coping with the stress associated with caregiving. Thus, older adults of different ethnic backgrounds may be at particular disadvantage in coping with caregiving because of the cultural beliefs that shape their family dynamics. Therefore, the current study will examine male and female older adult caregivers from different ethnic backgrounds in order to determine if there are differences in caregiver burden.

Moreover, on the basis of the literature it seems reasonable to surmise that effective coping can mediate any direct negative effects of the demographic factors (age, gender, ethnicity) on life satisfaction. That is, the established relationships that show lower life satisfaction in female caregivers of different ethnicities may be offset by 
adaptive and effective coping. However, it is also likely that less adaptive coping may increase the negative effects of the demographic characteristics on life satisfaction. That is, the established relationships showing that female ethnic caregivers experience lower life satisfaction may be found to be the result of maladaptive coping strategies.

Understanding the cultural/ethnic differences in coping with caregiving in later life will help us to better understand how the stress of caregiving is assessed, what resources are particularly useful in particular ethnic groups, and ultimately, may highlight points of intervention to help caregivers of different ethnic groups cope better.

The current study will test several specific hypotheses in order to determine the linkages among age, gender, ethnicity (i.e. ethnicity, ethnic beliefs), caregiver burden, coping with caregiving, and life satisfaction. Specifically, it is hypothesized that:

1) There will be age, gender, and ethnic differences in the caregiver burden experienced. Based on extant literature it is expected that older, female, Hispanic caregivers will report greater caregiver burden.

2) There will be age, gender, and ethnic differences in the coping strategies used to manage caregiver burden. Consistent with the coping literature, it is expected that caregivers will use a varied array of different coping strategies, some of which have been shown to be effective and useful at decreasing stress and burden (e.g., acceptance, reframing, problem solving, seeking social support) and some that have been shown to be less effective at managing the distress associated with caregiving (e.g., escape, avoidance) and may even be associated with increased levels of distress and lower levels of life satisfaction. Thus, it is expected that there will be a wide range of coping strategies used across 
caregivers and this study will determine how these patterns of coping vary across age, gender and ethnicity. Specifically it is expected, based on the extant literature that older, female, Hispanic caregivers will use more dysfunctional coping strategies, such as avoidance, and less active styles of coping aimed at changing, reducing, or negating the stress of caregiving.

3) There will be age, gender, and ethnic differences in mean levels of life satisfaction among the caregivers. Older, female, Hispanic caregivers will report less life satisfaction that their younger, male, non-Hispanic counterparts.

4) Coping strategies are hypothesized to mediate the relationship among demographic factors and life satisfaction. That is, part of the variability in life satisfaction will be explained by demographic factors such as age, gender, and ethnicity, however, coping strategies that are less effective will exacerbate the effects of caregiver burden on life satisfaction.

5) Lastly, on the basis of extant literature, it is hypothesized that there will be a significant relationship among burden and coping and life satisfaction, Specifically, higher rates of burden will be correlated with less effective coping and lower life satisfaction. 


\section{CHAPTER III}

\section{Methodology}

\section{Participants}

Participants in this study were volunteers over the age of 60 years old who were giving care to a loved-one or spouse with a chronic medical condition. A total of 103 older adults were recruited, with 54 older Hispanic adults and 49 older Non-Hispanic White adults. There were 17 male caregivers and 86 female caregivers. The mean age of the sample was 67.42 , with caregivers between the ages of 60 to 85 . Because of the nature of the caregiving experience, older adults had to have been in the caregiving role for a minimum of one year. Additionally, all participants were screened to determine whether they suffered from memory problems or dementia using the Mini-mental status exam (Folstein, Folstein, \& McHugh, 1975), and if so, they were excluded from participation. All older adult caregivers provided demographic information, self-reported health information, ethnocultural beliefs, completed the COPE inventory, the Burden Interview, The Satisfaction with Life scale, the Center for Epidemiological StudiesDepression Scale, and the State Trait Anxiety Scale.

\section{Measures}

Demographic data. A standard demographic questionnaire was given that gathers information on age, sex, education, occupation, socioeconomic status (as measured by the Hollingshead Index; Hollingshead, 1975). Additionally, ethnicity and language competencies were queried. Finally, as part of the demographic questionnaire a self-reported health index was given to assess the current health status of the caregiver 
and information will be gathered about the diagnosis, illness trajectory, severity and level of functioning of the care recipient.

Ethnocultural beliefs. Literature suggests that there is an interaction among ethnicity and cultural beliefs (Rozario, et al., 2008; Kim, et al., 2007). Therefore, to accurately assess the distinction among ethnicity and cultural two measures of cultural beliefs was administered. Familism was assessed using the Familism Scale (Losada, Knight, Marquez-Gonzalez, Montorio, Etxeberria, \& Peñacoba, 2008; Sabogal, Marin, Otero-Sabogal, VanOss Marin, \& Perez-Stable, 1987) adapted from the version created by Bardis (1959). The nine item questionnaire assesses three components of familism: familial obligations, perceived support from the family, and family as referents (Losada, et al., 2008; Sabogal, et al., 1987). The participants rated the items based on a 5 point likert scale ranging from (0) strongly disagree to (4) strongly agree. Higher scores indicate higher levels of familism.

Filial piety was assessed using the Filial Piety Scale (Ho, 1994). The 22 item questionnaire assesses aspects of filial piety, such as obedience, respect, ancestral worship and providing for one's parent (Ho, 1994). There are 11 negative items on the scale to measure diverging beliefs. Participants rated the items on a 6 point likert scale ranging from (1) strongly disagree to (6) strongly agree. Higher ratings on the scale indicate greater filial piety. Negative items were scored inversely (Ho, 1994).

The COPE. Coping strategies were assessed using the COPE scale (Carver, et al., 1989). The questionnaire includes 60 questions, four assessing each of the following coping behaviors: (1) active coping, (2) suppression of competing activities, (3) restraint coping, (4) instrumental social support, (5) emotional social support, (6) positive 
reinterpretation, (7) acceptance, (8) venting emotions, (9) turning to religion, (10) denial, (11) behavioral disengagement, (12) mental disengagement, and (13) planning. The instructions asked participants to answer each question about what they usually do to manage the stress associated with caregiving. Answers will range on a four point likert scale from (1) not very often to very often (4) (Carver, et al., 1989).

The Burden Interview. Levels of burden were measured using The Burden Interview (Zarit, et al., 1980). The 22 item questionnaire assesses subjective caregiver burden by using qualitative information (i.e., the affective response of the caregiver) to assess specific areas which are usually affected in a caregivers life (Zarit, et al., 1980). The instructions asked the participants to circle the response which best describes their feelings. Caregivers endorsed each item along a five point likert scale ranging from (0) never to (4) nearly always present (Zarit, et al., 1980). Higher ratings on the items indicated more elevated levels of burden.

The Satisfaction with Life Scale. Levels of life satisfaction were measured using The Satisfaction with Life Scale (Diener, et al., 1985). The narrowband five item questionnaire conceptualizes life satisfaction as a subjective appraisal of how close one's living conditions are to their ideal situation (Diener, et al., 1985). Questions are worded so that participants evaluate their lives on the basis of their own individual beliefs as to what constitutes the ideal (e.g., "The conditions of my life are excellent"). Caregivers rated their agreement with each item based on a seven point likert scale ranging from (1) strongly disagree to (7) strongly agree. A higher score on the scale indicates elevated levels of life satisfaction. 


\section{Center for Epidemiological Studies-Depression Scale. Symptoms of}

Depression were measured using the Center for Epidemiological Studies-Depression Scale (CES-D; Radloff, 1977). The 20 item self-report scale measures depressive symptomology in the general population (Radloff, 1977). The instructions asked the participant to state how often they have felt symptoms of depression over the past week. Participants rate items on a four point likert scale ranging from (0) rarely or none of the time to (3) most or all of the time (Radloff, 1977). Higher scores indicate increased depressive symptoms. Four items on the scale are inversely scored.

State Trait Anxiety Inventory. The participants' levels of stress were assessed using the State Trait Anxiety Inventory (STAI; Speilberger, 1983). The measure consists of two separate 20-item self-report scales which evaluate both state anxiety (i.e., what they are experiencing at that very moment) and trait anxiety (i.e., how they generally feel; Speilberger, 1983). The instructions on the state anxiety scale asked the participant to indicate how they feel at the moment. Participants' rate the items on a four point likert scale ranging from (1) not at all to (4) very much so (Speilberger, 1983). Higher scores indicate elevated levels of stress. Ten items are inversely scored.

The trait anxiety scale is structured similarly to the state anxiety scale. The instructions for the trait anxiety scale asked the participant to indicate how they generally feel (Speilberger, 1983). Participants' rated the items on a four point likert scale ranging from (1) almost never, to (4) almost always (Speilberger, 1983). Higher scores indicate elevated levels of stress. Ten items are inversely scored. 


\section{Procedure}

Participants were recruited from the community by reaching out to organizations that provide services to the elderly. Caregiver support groups and disease support groups were identified for recruitment, as well as day care centers for the elderly and senior recreational centers. At all locations information about the study was provided in flyers, leaflets, and announcements. Sign-up sheets with the principal investigator's contact information were distributed. Interested participants who contacted the principal investigator were screened and if they met the inclusion criteria were scheduled an interview at the time and location of convenience for the participant. All interviews were be face-to-face format and conducted by the principal investigator and research assistants. Interviews were conducted in English or Spanish depending on the preference of the participant. Prior to beginning the interview proper, each participant was informed of the nature of the study and issues of confidentiality, all questions were answered and then, if the participant agreed, an Informed Consent was presented and signed. Then the interview began with the demographic data followed by the experimental measures.

\section{Data Analytic Plan}

Data analysis was done using SPSS. A power analysis was conducted using the statistical computer program G Power 3.1 and a sample size of 50 elderly participants per ethnic category was found to be sufficient. A total of 103 participants were assessed.

The data analytic approach to test each hypothesis is as follows:

1) In order to determine whether or not there are age, gender, and ethnic differences (i.e., ethnicity, ethnocultural beliefs) in the caregiver burden and mental health, t-tests and ANOVAs were performed to test this hypothesis, with 
demographic variables as the independent variables and levels of burden and the levels of depression and anxiety as the dependent variable. In addition, Pearson Product Moment Correlational Analyses were conducted to further examine the hypothesis.

2) In order to determine if there are age, gender, and ethnic differences in the coping strategies correlational analyses were performed to determine if there are associations among the demographic factors and the dimensions of the COPE scale. For those variables that were statistically correlated, multiple regression analyses were performed in order to determine whether age, gender or ethnicity is the strongest predictor of coping styles employed. In these analyses, each demographic factor was treated as an independent variable and the outcome, coping, was the dependent variable. Thus, the relative weight of each demographic factor as a predictor of each coping strategy was assessed. A separate linear regression was performed for each major dimension of coping. 3) In order to determine whether there are demographic differences in life satisfaction a similar approach was taken. First, correlations were examined in order to determine which variables are related. Then, for those variables that were correlated, a hierarchical linear regression analyses were performed in order to determine whether age, gender or ethnicity is the strongest predictor of life satisfaction. In these analyses, each demographic factor was treated as an independent variable and the outcome, life satisfaction, was the dependent variable. Thus, the relative weight of each demographic factor as a predictor of each life satisfaction was assessed. 
4) Next, coping strategies were hypothesized to mediate the relationship among demographic factors and life satisfaction. That is, part of the variability in life satisfaction was expected to be explained by demographic factors such as age, gender, and ethnicity, however, coping strategies that are less effective were expected to exacerbate the effects of caregiver burden on life satisfaction. In order to test the mediational role of coping a series of hierarchal linear regressions were used following Holmbeck (2006) and Kraemer, Kiernan, Essex and Kupfer, (2008). Specifically, in order to test for mediation four criteria must be met.

First, there must be a significant relationship between the demographic factors and life satisfaction. Second, the relationship among the demographic factors and coping must be significant. Third, there must be a significant relationship between coping style and life satisfaction after controlling for demographic factors. And finally, the impact of demographic factors on life satisfaction should be significantly less after controlling for coping.

5) It is also possible that coping mediates the relationship between burden and life satisfaction. Therefore, in order to test the mediational role of coping a series of hierarchal linear regressions were used following Holmbeck (2006) and Kraemer, et al., (2008). Specifically, in order to test for mediation four criteria must be met. First, there must be a significant relationship between caregiver burden and life satisfaction. Second, the relationship among burden and coping must be significant. Third, there must be a significant relationship between coping style and life satisfaction after controlling for burden. And finally, the 
impact of caregiver burden on life satisfaction should be significantly less after controlling for coping. 


\section{CHAPTER IV}

\section{RESULTS}

\section{Descriptive Data}

Participants. A total of 103 participants were included in the present study, 17 $(16.5 \%)$ males and $86(83.5 \%)$ females. The mean age for the sample was $67.42(S D=$ 6.436), with ages ranging from 60 to 85 . There were 49 (47.6\%) Non-Hispanic White participants and $54(52.4 \%)$ Hispanic participants in this study.

Ethnocultural beliefs. Participants rated how they perceived their obligation to their family. The mean score for the Familism scale was $22.85(S D=6.15)$, with scores ranging from 3 to 36 . The mean score for the Filial Piety scale was $62.89(S D=10.87)$, with score ranging from 34 to 96 . Male $(M=65.65, S D=11.54)$ caregivers scored higher on filial piety than female caregivers $(M=62.35, S D=10.72)$. Male caregivers $(M=23.12, S D=4.94)$ also scored higher on familism than female caregivers $(M=$ 22.77, $S D=6.39$ ). Differences were also present among scores for the Filial Piety and Familism scale for Hispanic and Non-Hispanic White caregivers. Hispanic caregivers ( $M$ $=65.31, S D=9.35)$ scored higher on the Filial Piety scale than Non-Hispanic White caregivers $(M=62.89, S D=10.87)$. Similarly, Hispanic caregivers $(M=23.35, S D=$ 5.58) scored higher on the Familism scale than Non-Hispanic White caregivers $(M=$ $20.04, S D=5.55)$

Coping and Outcomes. Caregivers who participated in this study were asked to report the coping methods they used, their levels of depression, anxiety, life satisfaction, and caregiver burden. 


\section{Coping and Depression}

The relationship between coping and depression was investigated using Pearson Product Moment Correlational Analyses. The results indicate that depression does not have a significant relationship with Positive Reinterpretation and Growth $(r=-.062, p=$ .536), Use of Instrumental Social Support $(r=-.004, p=971)$, Religious Coping $(r=$ $.028, p=.781)$, Humor $(r=.121, p=.224)$, Restraint $(r=.184, p=.063)$, Use of Emotional Support $(r=-.047, p=.640)$, Substance Use $(r=.052, p=.605)$, Suppression of Competing Activities $(r=.152, p=.126)$, or Planning $(r=-.081, p=$ .413). Thus, the use of these coping strategies does not relate to depression in these caregivers.

Depression was found to have a positive correlation with Mental Disengagement $(r=.382, p=.001)$, Focus on Venting $(r=.346, p=.001)$, Denial $(r=.411, p=.001)$, and Behavioral disengagement $(r=.398, p=.001)$. The results indicate that those caregivers who are more likely to both mentally and behaviorally disengage, more likely to be in denial, more likely to focus on venting negative emotions are also more depressed.

Conversely, depression was found to be negatively correlated with Active Coping $(r=-.227, p=.021)$, and Acceptance $(r=-.301, p=.002)$. Those caregivers who are more depressed are using less active coping and acceptance, two coping strategies found to be beneficial for reducing burden.

The relationship between coping and anxiety was also investigated using a Pearson Product Moment Correlations. Results show that state anxiety is not significantly correlated with Focus on Venting $(r=.178, p=.072)$, Use of Instrumental 
Social Support $(r=-.115, p=248)$, Religious Coping $(r=.132, p=.184)$, Humor $(r=$ $-.117, p=.238)$, Restraint $(r=.104, p=.294)$, Use of Emotional Support $(r=-.127, p$ $=.202)$, Substance Use $(r=.077, p=.439)$, Suppression of Competing Activities $(r=$ $.017, p=.862)$, or Planning $(r=-.171, p=.085)$.

Results also show that state anxiety is positively correlated with Mental Disengagement $(r=.279, p=.004)$, Denial $(r=.285, p=.004)$, and Behavioral Disengagement $(r=.341, p=.0001)$. Furthermore, results indicate that state anxiety is negatively correlated with Positive Reinterpretation and Growth $(r=-.304, p=.002)$, Active Coping $(r=-.250, p=.011)$, Acceptance $(r=-.338, p=.0001)$. Thus, those caregivers who are higher in state anxiety, anxiety related to the state of caregiving, are more likely to cope with caregiving through mental and behavioral disengagement and denial. These results suggest that anxiety associated with caregiving leads to decreased use of beneficial coping strategies and increased use of dysfunctional coping strategies.

The relationship between coping and trait anxiety was also investigated.

Correlational analyses show that trait anxiety is not significantly correlated with Use of Instrumental Social Support $(r=-.048, p=.632)$, Active Coping $(r=-.140, p=.159)$, Religious Coping $(r=.026, p=.795)$, Humor $(r=-.049, p=.626)$, Restraint $(r=.192$, $p=.052)$, Use of Emotional Support $(r=-.068, p=.493)$, Substance Use $(r=.045, p$ $=.653)$, Suppression of Competing Activities $(r=.100, p=.315)$, or Planning $(r=-$ $.035, p=.729)$.

However, trait anxiety is positively correlated with Focus on Venting $(r=.418, p$ $=.0001)$, Mental Disengagement $(r=.348, p=.0001)$, Denial $(r=.196, p=.047)$, and Behavioral disengagement $(r=.321, p=.001)$. Moreover, results indicate that trait 
anxiety is negatively correlated with Positive Reinterpretation and Growth $(r=-.210, p=$ $.033)$, and Acceptance $(r=-.209, p=.034)$. Again, caregivers who are more anxious are engaging in less adaptive coping strategies.

The relationship between coping and burden was also investigated. Results show that burden is not significantly correlated with Positive Reinterpretation and Growth $(r=$ $-.056, p=.574)$, Use of Instrumental Social Support $(r=.188, p=.057)$, Denial $(r=$ $.138, p=.165)$, Religious Coping $(r=.163, p=.099)$, Substance Use $(r=-.084, p=$ $.401)$, Suppression of Competing Activities $(r=.069, p=.487)$, or Planning $(r=-.058$, $p=.561)$.

Caregiver burden is significantly, positively correlated with Mental Disengagement $(r=.355, p=.0001)$, Focus on Venting $(r=.438, p=.0001)$, Behavioral disengagement $(r=.313, p=.001)$, Restraint $(r=.305, p=.002)$, and Use of Emotional Support $(r=.201, p=.041)$. Moreover, results indicate that burden is negatively correlated with Active Coping $(r=-.198, p=.045)$, Humor $(r=-.209, p=$ $.034)$, and Acceptance $(r=-.205, p=.038)$. Thus, less adaptive coping strategies are highly correlated with greater caregiver burden while adaptive coping strategies correlate with less burden.

Finally, the relationship between coping and life satisfaction was investigated. Results show that burden is not significantly correlated with Positive Reinterpretation and Growth $(r=.155, p=.117)$, Mental Disengagement $(r=-.138, p=.164)$, Focus on Venting $(r=-.192, p=.052)$, Use of Instrumental Social Support $(r=-.002, p=.983)$, Active Coping $(r=.151, p=.128)$, Denial $(r=.132, p=.183)$, Religious Coping $(r=$ $.033, p=.741)$, Behavioral disengagement $(r=-.134, p=.177)$, Restraint $(r=-.102, p$ 
$=.305)$, Use of Emotional Support $(r=-.044, p=.660)$, Substance Use $(r=.133, p=$ $.180)$, Acceptance $(r=.099, p=.318)$, Suppression of Competing Activities $(r=-.073$, $p=.463)$, or Planning $(r=-.058, p=.561)$. However, one interesting positive correlation emerged. Results also show that life satisfaction is positively correlated with Humor $(r=.229, p=.020)$. Thus, those caregivers that are able to find humor or cope through humor tend to report higher life satisfaction.

A series of correlational analyses were also conducted to examine the linkages among mental health outcomes: depression, state anxiety, trait anxiety, burden, and life satisfaction. As expected, depression was found to be positively correlated with state anxiety $(r=.509, p=.0001)$, trait anxiety $(r=.698, p=.0001)$ and burden $(r=.512, p=$ .0001). Depression was also found to be negatively correlated with life satisfaction ( $r=$ $-.306, p=.002)$. State and trait anxiety were found to be positively correlated $(r=.570, p$ $=.0001)$. State anxiety was positively correlated with burden $(r=.411, p=.0001)$ and negatively correlated with life satisfaction $(r=-.421, p=.0001)$. Similarly, trait anxiety was found to be positively correlated with burden $(r=.528, p=.0001)$ and negative correlated with life satisfaction $(r=-.603, p=.0001)$. Lastly, there was a negative correlation between life satisfaction and caregiver burden $(r=-.504, p=.0001)$. These results indicate perhaps a profile of negative mental health patterns in caregivers.

Consistent with Carver et al., (1989), the individual coping strategies were combined to create two different types of coping, maladaptive coping and adaptive coping. Further extending the results reported above, correlational analyses showed that maladaptive coping was significantly correlated with increased burden, $(r=.399, p=$ $.0001)$, increased state, $(r=.437, p=.0001)$ and trait anxiety $(r=.375, p=.0001)$, and 
increased depression, $(r=515, p=.001)$. Thus, taken together results show that on the level of individual coping strategies and on the level of general coping styles dysfunctional coping leads to negative mental health outcomes for caregivers.

\section{Demographic Differences in Burden}

Hypothesis one examined demographic differences between burden and mental state among participants in the study. It was hypothesized that older caregivers would report greater levels of caregiver burden. Similarly, female and Hispanic caregivers were expected to experience greater caregiver burden than their male and Non-Hispanic White counterparts.

The relationship between age and burden was investigated using Pearson Product Moment Correlations. There was a small, marginally significant correlation between the two variables $(r=-.173, p=.080)$. In other words, results suggest a trend that older caregivers are experiencing lower levels of caregiver burden, while younger caregivers experience higher levels of burden. But this result was not significant thus must be interpreted with caution.

An independent samples t-test was conducted to compare the burden levels for males and females. Results showed no significant difference $t(101)=.298, p=.78$, which indicates that while females may report greater burden $(M=30.63, S D=14.79)$ than males $(M=29.41, S D=18.20)$ this difference was not significant. Similarly, an independent samples t-test was conducted to compare the burden levels for Hispanic and Non-Hispanic White participants. Results showed no significant difference $t(101)=.424$, $p=.67$ between the two groups. Although Non-Hispanic White caregivers may report 
higher levels of burden $(M=31.10, S D=15.48)$ than Hispanic caregivers $(M=29.81, S D$ $=15.26)$, the results were not found to be significant.

An Analysis of Variance was also conducted to investigate the difference between levels of caregiver burden, depression, and anxiety among male and female caregivers. There was no statistical significance between gender and depression $F(1,101)=.003, p=$ .956 , state anxiety $F(1,101)=.010, p=.922$, trait anxiety $F(1,101)=.623, p=.432$ or burden $F(1,101)=.089, p=.766$.

Lastly, several Analyses of Variances were conducted to investigate the difference between levels of caregiver burden, depression, and anxiety among Hispanic and Non-Hispanic White caregivers. There was no statistical significance between ethnicity and depression $F(1,101)=.440, p=.508$, state anxiety $F(1,101)=.488, p=$ .486 , trait anxiety $F(1,101)=2.155, p=.145$ or burden $F(1,101)=.180, p=.672$. In sum, contrary to initial hypotheses there were no differences in the demographic factors (age, gender, and ethnicity) and mental health outcomes.

\section{Demographics Differences in Coping}

The second hypothesis for this study examined the relationship between demographics and coping methods used. It was expected that older caregivers would use more dysfunctional methods of coping. Female and Hispanic caregivers were also expected to use less effective coping methods to manage their caregiving role.

The relationship between age and methods of coping used was investigated using the Pearson Product Moment Correlations. There was no significant correlation between age and Positive Reinterpretation and Growth $(r=-.059, p=.553)$, Mental disengagement $(r=-.071, p=.474)$, Focus on and venting of emotions $(r=-.056, p=$ 
$.575)$, Use of instrumental social support $(r=-.100, p=.314)$, Active coping $(r=-$ $.044, p=.655)$, Denial $(r=.020, p=.839)$, Religious coping $(r=.136, p=.171)$, Humor $(r=-.024, p=.813)$, Behavioral disengagement $(r=.055, p=.579)$, Restraint $(r=.058, p=.563)$, Use of emotional social support $(r=-.116, p=.245)$, Substance use $(r=-.163, p=.099)$, Acceptance $(r=.097, p=.331)$, Suppression of competing activities $(r=.142, p=.152)$, or Planning $(r=-.004, p=.967)$. The results suggest that age does not have a significant relationship with these forms of coping.

An independent samples t-test was conducted to compare the coping methods between males and females. Results showed no significant difference between gender and Positive Reinterpretation and Growth $t(101)=-1.286, p=.201$, with males $(M=$ $11.76, S D=3.07)$ reporting it less frequently than females $(M=12.68, S D=2.62)$, Mental disengagement $t(101)=-.155, p=.877$, with males $(M=8.12, S D=2.71)$ reporting it less frequently than females $(M=8.22, S D=2.46)$, Focus on and venting of emotions $t(101)=-.991, p=.324$, with males $(M=8.05, S D=3.19)$ reporting it less frequently than females $(M=8.81, S D=2.80)$, Active coping $t(101)=-1.327, p=.188$, with males $(M=11.52, S D=2.27)$ reporting it less frequently than females $(M=12.27$, $S D=2.10)$, Denial $t(101)=-1.554, p=.123$, with males $(M=4.76, S D=1.56)$ reporting it less frequently than females $(M=5.79, S D=2.62)$, Humor $t(101)=.197, p=.844$ with males $(M=8.41, S D=4.39)$ reporting it more frequently than females $(M=8.19$, $S D=4.29)$, Behavioral disengagement $t(101)=-.086, p=.931$ with males $(M=5.88$, $S D=2.09)$ reporting it less frequently than females $(M=5.93, S D=2.85)$, Restraint $t(101)=-.939, p=.350$, with males $(M=9.12, S D=2.39)$ reporting it less frequently than females $(M=9.79, S D=2.75)$, Acceptance $t(101)=-.567, p=.572$ with males $(M$ 
$=12.52, S D=3.87)$ reporting it less frequently than females $(M=13.00, S D=2.97)$, Suppression of competing activities $t(101)=.291, p=.772$, with males $(M=10.35, S D$ $=2.62$ ) reporting it more frequently than females $(M=10.16, S D=2.43)$, or Planning $t(101)=.154, p=.878$ with males $(M=12.18, S D=3.30)$ reporting it more frequently than females $(M=12.05, S D=2.80)$. Contrary to initial expectations, there are no gender differences in the use of these different coping strategies in this sample.

There was a significant difference, however, between men and women regarding Use of instrumental social support $t(101)=-2.58, p=.011$, with males $(M=7.94, S D=$ 3.54) reporting it less frequently than females $(M=10.37, S D=3.53)$. Males $(M=8.59$, $S D=4.62)$ were also significantly less likely to use Religious coping $t(101)=-3.291, p$ $=.001$, than females $(M=12.26, S D=4.11)$. Females $(M=10.02, S D=3.38)$, also endorse a greater Use of emotional social support $t(101)=-3.235, p=.002$, than males $(M=7.18, S D=2.96)$. There was a marginally significant difference between males and females regarding Substance use $t(101)=4.109, p=.071$, with males $(M=5.82, S D=$ 3.57) reporting it more frequently than females $(M=4.14, S D=.65)$. Thus, gender differences did emerge in the use of instrumental social support, emotional support, and religious coping with females generally reporting more of these strategies than males.

An independent samples t-test was conducted to compare coping methods between Hispanic and Non-Hispanic White caregivers. Results showed no significant difference among the groups on Mental disengagement $t(101)=-.080, p=.937$ with, Focus on and venting of emotions $t(101)=-1.327, p=.188$, Use of instrumental social support $t(101)=-1.154, p=.251$, Active coping $t(101)=.516, p=.607$, Behavioral disengagement $t(101)=.018, p=.985$, Restraint $t(101)=-.051, p=.960$, Substance use 
$t(101)=-.776, p=.439$, Suppression of competing activities $t(101)=-.199, p=.843$, or Planning $t(101)=.397, p=.692$. Contrary to initial hypotheses, there were no significant differences among Hispanics and Non-Hispanic Whites on these coping strategies.

Interestingly though, ethnic differences did emerge in the use of these coping strategies. Specifically, there was a significant difference, among Hispanic and NonHispanic White caregivers regarding Positive Reinterpretation and Growth $t(101)=$ $2.668, p=.009$, with Hispanic caregivers $(M=13.20, S D=2.10)$ reporting it more frequently than Non-Hispanic White caregivers $(M=11.79, S D=3.10)$. Thus, Hispanic caregivers seem to be able to derive more positive meaning from caregiving than their non-Hispanic White counterparts. Consistent with initial hypotheses, Hispanic caregivers $(M=6.33, S D=3.09)$ report significantly greater use of Denial $t(101)=3.270, p=.002$, than Non-Hispanic White caregivers $(M=4.83, S D=1.26)$. Religious coping $t(101)=$ $3.224, p=.002$, was found to be lower in Non-Hispanic White caregivers $(M=10.22, S D$ $=4.95)$ than Hispanic caregivers $(M=12.94, S D=3.38)$. Hispanic caregivers $(M=$ $10.13, S D=4.36$ ) are significantly more likely to use Humor $t(101)=5.420, p=.0001$ than Non-Hispanic White caregivers $(M=6.12, S D=3.09)$. And finally, a significant group difference was found for Acceptance $t(101)=2.071, p=.041$ with Hispanic caregivers $(M=13.52, S D=2.85)$ reporting it less frequently than Non-Hispanic White caregivers $(M=12.27, S D=3.29)$. Although it did not reach significance, consistent with initial hypotheses and previous research, there was a marginally significant difference between Hispanic and Non-Hispanic White caregivers regarding Use of emotional social support $t(101)=-1.751, p=.083$, with Hispanic caregivers $(M=8.98$, 
$S D=2.91)$ reporting it less frequently than Non-Hispanic White caregivers $(M=10.18$, $S D=3.29)$.

Two Multivariate Analyses of Variance were performed to assess the relationship between gender, ethnicity, and coping methods used. The independent variables used were gender and ethnicity, and the dependent variable was coping. There was a marginally statistically significant difference in gender influencing coping $F(2,100)=$ 2.943, $p=.057$; Wilk's Lambda $=.944$; eta squared $=.056$. However, there was no significant relationship between ethnicity and coping $F(2,100)=2.424, p=.094$; Wilk's Lambda $=.954$; eta squared $=.046$. These findings suggest that gender accounts for more of the variance seen in coping skills used than ethnicity.

Multiple regression analysis was used to test if demographics significantly predicted coping methods used. A separate linear regression was done for each coping method that was highly correlated. The results of the regression indicated that demographics explained $9 \%$ of the variance, $R^{2}=.090, F(3,99)=3.227, p=.024$ in the use of Positive Interpretation and Growth. It was found that ethnicity significantly predicted the use of Positive Interpretation and Growth (Beta $=.071, p=.007)$. The results of the regression indicated that demographics explained $8 \%$ of the variance, $R^{2}$ $=.080, F(3,99)=2.869, p=.040$ in the Use of Instrumental Social Support. It was found that gender significantly predicted the Use of Instrumental Social Support (Beta = $.061, p=.012)$. The results of the regression indicated that demographics explained $20 \%$ of the variance, $R^{2}=.200, F(3,99)=8.251, p=.0001$ in the use of Religious Coping. It was found that gender significantly predicted the use of Religious Coping $($ Beta $=.098, p=.001)$, as did ethnicity $($ Beta $=.094, p=.001)$. The results of the 
regression indicated that demographics explained $13 \%$ of the variance, $R^{2}=.134, F(3,99)$ $=5.120, p=.002$ in the Use of Emotional Support. It was found that gender significantly predicted the Use of Emotional Support (Beta $=.098, p=.002$ ). The results

of the regression indicated that demographics explained $15 \%$ of the variance, $R^{2}=.149$, $F(3,99)=5.798, p=.001$ in Substance Use. It was found that gender significantly predicted the Substance Use $($ Beta $=.144, p=.0001)$. The results of the regression indicated that demographics explained $3 \%$ of the variance $R^{2}=.034, F(3,99)=1.162, p$ $=.328$ in the use of Suppression of Significant Activities, but it was not significant. The results of the regression indicated that demographics explained $12 \%$ of the variance, $R^{2}$ $=.124, F(3,99)=4.659, p=.004$ in Denial. It was found that ethnicity significantly predicted Denial $($ Beta $=.086, p=.002)$. The results of the regression indicated that demographics explained $23 \%$ of the variance, $R^{2}=.225, F(3,99)=9.596, p=.001$ in Humor. It was found that ethnicity significantly predicted Humor $($ Beta $=.225, p=$ $.0001)$. The results of the regression indicated that demographics explained $6 \%$ of the variance, $R^{2}=.058, F(3,99)=2.031, p=.114$ in Acceptance, but it was not significant. Thus, the demographic factors show different patterns of predictive associations with different coping strategies.

\section{Demographics Differences in Life Satisfaction}

The third hypothesis sought out to determine if there existed a significant difference between demographics and life satisfaction. It was expected that older caregivers would report less life satisfaction. Similarly, female and Hispanic caregivers would also report less life satisfaction than their male Non-Hispanic White counterparts. The relationship between life satisfaction and age was investigated using a Pearson 
Product Moment Correlations. Results indicate that there is no significant relationship between age and life satisfaction $(r=.0001, p=.996)$.

An independent samples t-test was conducted to compare the life satisfaction between males and females. Results show that there is a marginally significant relationship between gender and life satisfaction $t(101)=-1.890, p=.062$, which indicates that although male caregivers $(M=22.23, S D=8.34)$ reported lower life satisfaction than females $(M=25.489, S D=6.07)$, the relationship is only marginally significant. An independent samples t-test was also conducted to compare life satisfaction between Hispanic and Non-Hispanic White caregivers. Results show that there is a significant difference in life satisfaction between Hispanic and Non-Hispanic White caregivers $t(101)=2.000, p=048$, signifying that Hispanic caregivers $(M=$ 26.17, $S D=6.59$ ) experience greater life satisfaction than Non-Hispanic White caregivers $(M=23.61, S D=6.34)$ in this sample.

Multiple regression analysis was used to test if demographics significantly predicted life satisfaction. The results of the regression indicated that demographics explained $7 \%$ of the variance, $R^{2}=.073, F(2,100)=3.913, p=.023$ in life satisfaction. It was found that ethnicity significantly predicted life satisfaction $($ Beta $=.038, p=.044)$. Gender only marginally significantly predicted life satisfaction $(\operatorname{Beta}=.035, p=.057)$.

\section{The Role of Familism and Filial Piety}

Although it was not included in the hypotheses of the study, the role of familism and filial piety were examined as proxies of ethnicity. Results show that although familism was not significantly related to adaptive or maladaptive coping, it did have a significant influence on mental health outcomes. Specifically, familism was found to be 
highly correlated with life satisfaction, $(r=.202, p=.04)$. Those caregivers who reported greater familistic beliefs also reported higher life satisfaction. Moreover, higher familism was associated with lower rates of burden, $(r=-.233, p=.02)$ and lower rates of trait anxiety, $(r=-.226, p=.02)$. Filial piety was found to be significantly correlated with maladaptive coping, $(r=.201, p=04)$, indicating perhaps that some aspects of the concept of filial piety lead to less effective coping.

To further examine the role of familism a stepwise hierarchical linear regression analysis was performed with burden as the dependent measure and age, gender, ethnicity, familism and filial piety as the independent measures. The overall regression model was significant $F(1,102)=5.81, p=.02$. Of the carriers, only familism was a significant predictor of burden claiming twenty-three percent of the variance in burden (Beta $=-.233$, $p=.02$ ). Similarly, when a stepwise hierarchical linear regression was computed with life satisfaction as the mental health outcome and age, gender, ethnicity, familism and filial piety as predictors, again the model was significant, $F(1,102)=4.28, p=.04$ and familism was the only carrier to enter the model and was found to predict twenty percent of the variance in life satisfaction (Beta $=.202, p=.41$ ). The regression with depression as the outcome was not significant. Nor were the regressions predicting state or trait anxiety.

\section{Coping as a Mediator for Demographics and Life Satisfaction}

The fourth hypothesis stated that coping was expected to mediate the relationship among demographic factors and life satisfaction. In order to test the mediational role of coping methods a series of hierarchal linear regressions were used following Holmbeck (2006) and Kraemer, et al., (2008). Carver, et al., (1989), discussed a 
theoretically driven and empirically supported conceptualization of coping methods being either adaptive or maladaptive. The author's distinction was used as a guide to consolidate all subscales from the COPE inventory (Carver, et al., 1989) to either adaptive coping methods or maladaptive coping methods. The following regressions were based on these two variables.

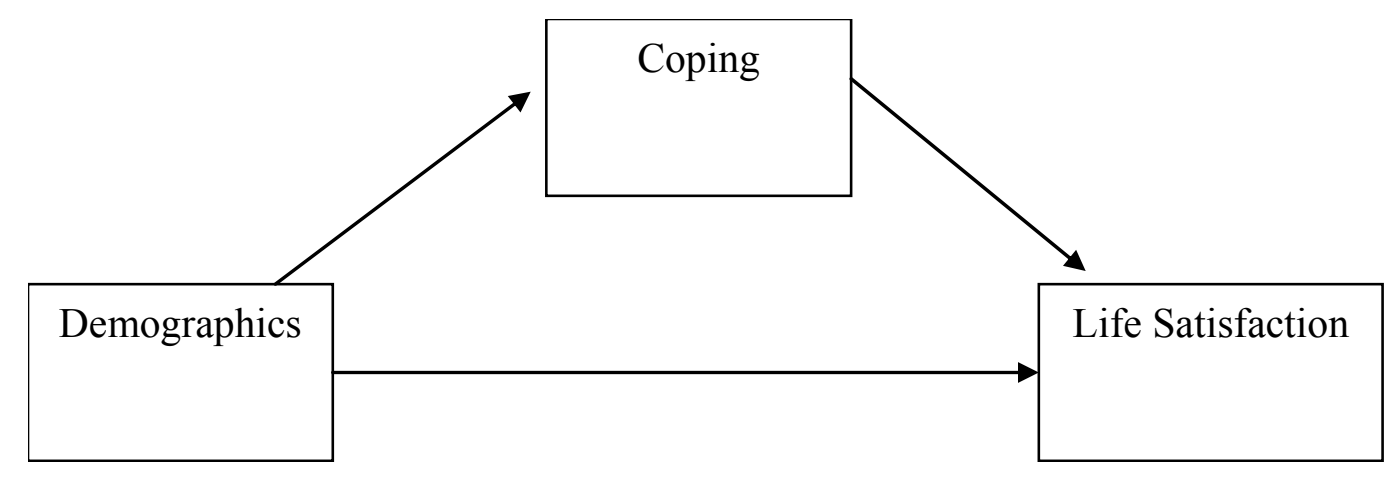

First, a hierarchical linear regression was conducted to determine if there is a significant relationship between the demographic factors and life satisfaction. Demographics are predictor variables expected to be significantly associated with life satisfaction. In order for coping to serve as a mediating factor, this relationship must exist. In step one of the hierarchical linear regressions used to test this linkage, age and gender were entered into the model $\left(R^{2}=.034\right)$, and in step two, ethnicity was added $\left(R^{2}\right.$ $=.073)$. The total models $R^{2}$ change was .039 and was significant $(p=.045)$. The model as a whole was found to be marginally significant; $F(3,99)=2.587, p=.057$. In sum, the data suggests that there is a significant relationship between demographic factors and life satisfaction, thus meeting the first criteria necessary to show coping as a mediator.

Second, a hierarchical linear regression was conducted to determine if there is a significant relationship between the demographic factors and adaptive coping. In order 
for coping to be a mediating variable, a significant linkage must exist between demographics factors and adaptive coping. In step one of the hierarchical linear regression conducted to investigate this relationship, age and gender were entered into the model $\left(R^{2}=.055\right)$, and in step two, ethnicity was added $\left(R^{2}=.101\right)$. The total models $R^{2}$ change was .46 and was significant $(p=.026)$. The model as a whole was found to be significant, $F(3,99)=3.717, p=.014$. In sum, the data suggest that there is a significant relationship between demographic factors and adaptive coping, thus meeting one part of the second criteria. The linear regression shows that demographics account for $4.6 \%$ of the variance in the use of active coping. In order for coping to serve as a mediating variable between demographics and life satisfaction, this relationship had to exist to account for the impact that age, gender, and ethnicity have on life satisfaction as an outcome.

Third, a hierarchical linear regression was conducted to determine if there is a significant relationship between the demographic factors and maladaptive coping. A separate linear regression was necessary to ensure that coping, as a whole, is significantly related to demographics. In step one, age and gender were entered into the model $\left(R^{2}=\right.$ $.000)$, and in step two, ethnicity was added $\left(R^{2}=.001\right)$. The total models $R^{2}$ change was .001 but was not significant $(p=.765)$. The model as a whole was not found to be significant; $F(3,99)=.039, p=.990$. In sum, the data suggests that there is no significant relationship between demographic factors and maladaptive coping, thus failing to meet another part of the second criteria. The results indicate that age, gender, and coping, do not account for variance seen in the use of maladaptive coping. Since this 
relationship does not exist, coping cannot be identified as a mediator between demographics and life satisfaction.

\section{Coping as a Mediator for Burden and Life Satisfaction}

For the final hypothesis of the study, a series of hierarchal linear regressions were used following Holmbeck (2006) and Kraemer, et al., (2008) in order to test the mediational role of coping between burden and life satisfaction. Caregiver burden was expected to be a predicting variable for life satisfaction, however, coping was thought to mediate this relationship. First, a hierarchical linear regression was conducted to determine if there was a significant relationship between caregiver burden and life satisfaction. Caregiver burden was entered in to the model $\left(R^{2}=.256\right)$ and was significant $(p=.0001)$. The model as a whole was found to be significant; $F(2,101)=$ $34.718, p=.0001$. In sum, the data suggest that there is a significant relationship between burden and life satisfaction, thus meeting the first criteria and signifying that caregiver burden accounts for variance seen in levels of life satisfaction.

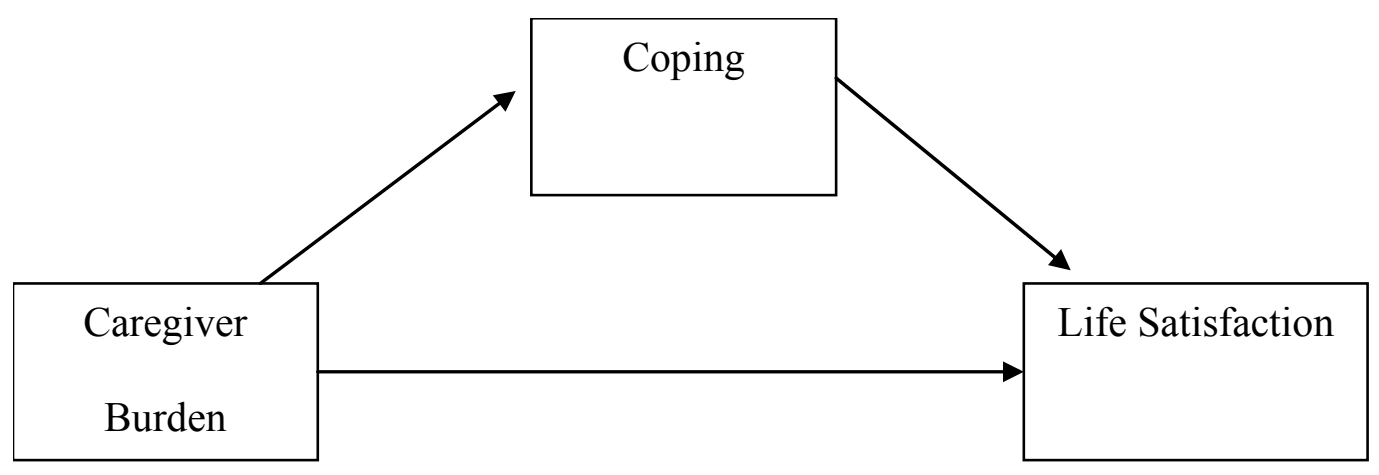

Second, a hierarchical linear regression was conducted to determine if there is a significant relationship among burden and coping, which must exist to consider coping a mediating variable between burden and life satisfaction. In step one, adaptive coping was 
entered into the model $\left(R^{2}=.011\right)$, and in step two, maladaptive coping was added $\left(R^{2}=\right.$ $.022)$. The total models $R^{2}$ change was .11 and was significant $(p=.0001)$. The model as a whole was found to be significant; $F(2,100)=9.525, p=.0001$. In sum, the data suggest that there is a significant relationship between burden and coping, thus meeting the second criteria. The data also show that burden is significantly related to coping as a whole, and accounts for $11 \%$ of the variance seen in the use of adaptive and maladaptive coping.

Third, a hierarchical linear regression was conducted to determine if there is a significant relationship between coping style and life satisfaction after controlling for burden. Further analyses were necessary to see if this model, which presents coping as a mediating variable, is acceptable. In step one, burden were entered into the model $\left(R^{2}=\right.$ $.256)$, and in step two, coping was added $\left(R^{2}=.284\right)$. The total models $R^{2}$ change was .28 but was not significant $(p=.206)$. The model as a whole was found to be significant; $F(3,99)=13.085, p=.0001$. In sum, the data suggest that there is no significant relationship between coping and life satisfaction after controlling for burden, thus failing to meet the third criteria. The results indicate that caregiver burden and coping style do not significantly account for the variance seen in life satisfaction. Thus, coping cannot be seen as a mediator for burden and life satisfaction 


\section{CHAPTER V}

\section{DISCUSSION}

The focus of the present research study was to extend the current understanding of how life satisfaction is impacted by caregiver burden by investigating whether or not there are demographic differences in coping strategies used to handle caregiving. The results indicate that there is indeed a relationship between burden and life satisfaction. More specifically, as caregiver burden increases, life satisfaction decreases. Coping strategies were not found to mediate this relationship in this particular sample. Caregiver burden was also found to relate to depression and anxiety. Results show that as caregiver burden increases, so does state anxiety, trait anxiety, and levels of depression experienced by caregivers. Furthermore, as these mental health variables increase, caregivers tend to experience lower levels of life satisfaction. Results show that women tend to employ more adaptive methods of coping than men, such as to improving their support systems and seeking advice from others. Ethnicity also influenced caregivers' choice of coping style. Hispanic caregivers were more likely to use religion, as well as humor, as a coping mechanism, which may explain why female and Hispanic caregivers were more likely to experience greater levels of life satisfaction. The results of the current study replicate earlier research and emphasize the negative mental health impact of caregiver burden and dysfunctional coping in the context of caregiving, and point to potential pathways for effective interventions to encourage more adaptive coping to reduce caregiver burden. 


\section{Outcomes of Caregiving}

The main goal of the present research study was to investigate the relationship between caregiver burden and life satisfaction and examine the role that demographics play in caregivers' choice of coping skills. Analyses conducted on the demographic differences in burden experience did not support the study's hypothesized relationship. Older caregivers were expected to experience greater levels of caregiver burden on the basis of empirical evidence suggesting age increases burden (Choo, et al., 2003; Minnes, et al., 2007; Roberto, 1995). However, results from the present study did not support that finding. Conversely, results indicate that as caregivers age, they experience lower levels of caregiver burden, while younger caregivers are experiencing higher levels of burden. Furthermore, there was no evidence that age is associated with a worsened mental state while in a caregiving role. One possible explanation for this may be that the caregiving elders in the present study were healthier and more physically able than counterparts in previous studies. Similarly, the resources available to caregivers in this sample may have been greater than in other previous samples. Given the large network of family and community resources available to Hispanic caregivers, perhaps burden is lessened due to the social support gleaned from these resources. However, these stipulations remain conjecture, as they were not empirically tested in the present study.

On the basis of the accumulated literature it was expected that female caregivers would experience greater burden (Choo, et al., 2003; Fitting, et al., 1986; WaldronPerrine, et al., 2009). However, no significant differences were found between the levels of burden experienced between male and female caregivers. The lack of a significant relationship between gender and caregiver burden in the present study may be attributed 
to the uneven distribution of male and female participants in the study. Male caregivers accounted for only a small percentage (16.5\%) of all the caregivers interviewed. While historically caregiving has always fallen to females, and research suggests that females are, in fact, better suited for caregiving (Collins, et al., 1997), such a notion may be especially true in Hispanic families in which traditional gender roles are prevalent (Galanti, 2003). Thus, in recruiting caregivers for the present study, it was challenging to find male caregivers. The male caregivers who did participate may have been less burdened and still able to manage the care of their loved ones well, and thus they did not differ from significantly from the females in the sample. Again, caution must be used in extrapolating from the results, as this suggestion was not tested empirically.

Contrary to initial hypotheses, the present results also failed to support the relationship between ethnicity and caregiver burden. Hispanic caregivers were expected to experience higher levels of burden consistent with previous research showing that Hispanic caregivers experience higher levels of depression and distress than NonHispanic White caregivers (Pinquart, et al., 2005; Valle, et al., 2004). Other studies report that Hispanic caregivers stated that they are in need of more social support (Adams, et al., 2002), both of which contribute to increased burden (McCallum, et al., 2007). However, in the present study Hispanic and Non-Hispanic caregivers did not differ in terms of self-reported caregiver burden, depression, or anxiety, which may be the result of Hispanic caregivers endorsing ethnocultural beliefs, such as familism and filial piety (Kim, et al., 2007; McCallum, et al., 2007; Pinquart, et al., 2005). Research has shown that familism may affect levels of caregiver burden and, when accompanied with social support, may improve outcomes (Kim, et al., 2007; McCallum, et al., 2007). 
The fact that Hispanics in the present sample had higher levels of life satisfaction could be seen as support for previous research that shows that Hispanic caregivers find their role to be more rewarding than Non-Hispanic White caregivers (Pinquart, et al., 2005). The results of the present study do show overwhelming evidence that familism increases life satisfaction, and reduces burden and anxiety. Thus, it is a beneficial belief when it comes to the experience of caregiving.

In the present study, it was anticipated that demographic factors such as age, gender, and ethnicity would influence the differential use of coping strategies. Specifically, in line with previous studies, it was expected that with advancing age, caregivers would employ more dysfunctional methods of coping as older caregivers tend to use more passive methods than their younger counterparts (Birkeland \& Natvig, 2009; Folkman et al., 1987). However, in the present study there were no significant linkages among age and individual coping strategies. Moreover, when individual coping strategies were consolidated into adaptive coping and maladaptive coping, age still did not have a significant relationship with coping. The results found in the present study may be due to the fact that this caregiving sample was relatively young $(M=67.42$ years old) compared to samples in previous research. Thus, the caregivers in the present sample may still be relatively healthy and capable of managing the daily requirements of caregiving and thus may not appraise their coping (Carver, et al., 1989). The literature suggests that middle-aged women who are caregivers are often more stressed than spousal caregivers giving care in later life, in part because the middle aged caregivers must give care to both the younger generation (their own children) as well as the older generation (their parents; See Brody, 1981; Stone, Cafferata, \& Sangl, 1987; Treas, 
1979). However, in the present study the research sample was developmentally beyond middle-age but not yet old enough that their own health and physical limitations created added burden within the caregiving context.

Gender was also expected to influence the coping methods chosen by caregivers. It was hypothesized that female caregivers would employ more maladaptive methods of coping, derived from the literature that states that women tend to experience greater distress and difficulties with caregiving than men (Adams, et al., 2002; Navaie-Waliser, et al., 2002). Previous research also showed that females typically rely on emotionfocused coping strategies rather than problem focused coping for dealing with stress (Collins, et al., 1997; Hooker, et al., 2000; Kristensson Ekwall, et al., 2006; WaldronPerrine, et al., 2009). However, the results from the present study indicate that women were more likely to choose Use of Instrumental Social Support, Use of Emotional Support, and Religious coping, which is contrary to the hypothesized pattern, since these three coping strategies have been categorized as adaptive coping methods (Carver, et al., 1989). Once again, the lack of significant gender differences may simply be the result of the largely discrepant sample sizes among genders in the present study.

In the present study, it was expected that Hispanic caregivers would employ more dysfunctional methods of coping than Non-Hispanic White caregivers. While there is little previous research suggesting differential use of coping among different ethnic caregivers, this relationship was anticipated due to research findings showing elevated levels of depression and distress among Hispanic caregivers compared with caregivers of other ethnic groups (Adams, et al., 2002; Pinquart, et al., 2005; Valle, et al., 2004). The present study, which explicitly examined different coping strategies, was supportive of 
the notion that Hispanic caregivers employed maladaptive coping styles. Hispanic caregivers were more likely to use Denial, which is seen as a maladaptive coping skill (Carver, et al., 1989). Hispanic caregivers were also less likely to choose Acceptance as a coping skill and reported a lower Use of Emotional Support than Non-Hispanic White caregivers. Conversely, the results show that Hispanic caregivers chose Positive Reinterpretation and Growth, and Humor more frequently than Non-Hispanic White caregivers. Thus, while it was found that Hispanic caregivers are using some maladaptive coping strategies they were also found to be using some adaptive coping strategies. Taken together these individual strategies may balance out, and that may explain why Hispanic caregivers did not experience greater burden and why they still show higher life satisfaction from their caregiving experiences. Findings from the present study are important because a novel approach of investigating micro-level coping strategies as well as macro-level coping strategies was used. Whereas no ethnic differences emerged at the macro-level (i.e., adaptive versus maladaptive coping), ethnic differences did emerge at the micro-level (i.e., the level of specific strategies) and this highlights the importance of individual actions both in terms of managing coping effectively and in terms of pointing to specific techniques that could be learned to manage the stress and burden of caregiving.

Differences in the coping strategies employed are also of interest because of the impact these strategies have on levels of depression (Gallagher-Thompson, Gray, Dupart, Jimenez \& Thompson, 2008; McQueeney, Stanton \& Sigmon, 1997; Nolen-Hoeksema, 1987; Nolen-Hoeksema, 1991). Certain coping styles, such as Focusing on and Venting Emotions, may result in longer and more severe periods of depression (Nolen-Hoeksema, 
1991). Researchers have found that creating psychoeducational interventions where resources are provided to those struggling with symptoms of anxiety and depression can greatly improve the participants' outcomes (Gallagher-Thompson, et al., 2008; McQueeney, et al., 1997). Efforts to modify the use of ineffective coping skills by providing more adaptive alternatives have provided promising results. Caregivers of dementia patients have been found to have reduced overall life stress and depressive symptoms after such a treatment (Gallagher-Thompson, et al., 2008). Most importantly, this effect can be seen across ethnicities. Gallagher-Thompson, et al., (2008), provided psychoeducational interventions to both Hispanic and Non-Hispanic White caregivers in both English and Spanish in a treatment group focusing on modify coping skills used. Their intervention resulted in lower levels of depression, perceived psychological stress, and conditional bother (burden experienced by certain behaviors care recipients employed).

In line with a vast amount of previous research demonstrating the linkages among caregiver burden and life satisfaction, in the present study it was expected that demographic factors such as age, gender, and ethnicity would differentially influence these outcomes. Our results do not show any age effects and the explanation may be the age of the sample as mentioned above. Gender only marginally influenced life satisfaction in this sample of caregivers, such that female caregivers report slightly higher levels of life satisfaction than male caregivers. Once again, it must be stated that the unequal groups of male and female participants may account for the lack of a stronger relationship between the two variables 
Lastly, Hispanic caregivers were expected to report lower levels of life satisfaction than Non-Hispanic White caregivers because of research that states that Hispanic caregivers experience higher levels of depression than Non-Hispanic White caregivers (Adams, et al., 2002; Cox, et al., 1990; Valle, et al., 2004). Contrary to initial hypotheses, Hispanic caregivers experience greater levels of life satisfaction than NonHispanic White caregivers, possibly as a result of ethnocultural beliefs and how Hispanic caregivers perceive their caregiving role. Hispanic caregivers reported more elevated levels of familism and filial piety than Non-Hispanic White caregivers, which may be a factor influencing their life satisfaction.

Finally, the present study sought to examine the mediational role of coping to determine if more adaptive coping strategies may lessen the impact of burden. More specifically, on the basis of previous research demonstrating that male caregivers who use less adaptive methods of coping were found to experience higher levels of distress (Rose, et al. 1997), while women who use more adaptive methods of coping experienced lower levels of depression (Essex, et al., 1999). A model was created in which assumptions needed to be met in order to assume a mediational role of coping (Holmbeck, 2006; Kraemer, et al., 2008). While significant linkages among demographic factors and life satisfaction were found, and linkages among coping and life satisfaction were found, there were no significant linkages among demographic factors and coping therefore, it could not be concluded that coping mediates the relationship between demographic characteristics and life satisfaction. It is highly likely that the mediational role of coping would have emerged if the demographic factors had been more balanced across the sample. Not only did this study include small samples of caregivers within 
each ethnic group, the imbalance among genders was a significant disadvantage. Moreover, it could be that the distinctions among adaptive and maladaptive coping strategies (Carver, et al., 1989) were not the proper approach at a constructual level. Evidence of this can be seen in the significant relations that emerged when individual coping strategies were examined that then were not found when examining coping at the level of adaptive/maladaptive. For several methodological reasons, it is possible that the analyses conducted here were not able to detect the mediational role of coping. In the present study, a significant relationship among burden and life satisfaction was found, yet burden and coping were not significantly related. The level of burden experienced in the current sample may be relatively low, in part because the caregivers were younger and perhaps more able to manage the stress of caregiving, which may explain the results obtained.

\section{Limitations}

The present study has several limitations that should be taken into account. First, it was a significant challenge to recruit caregivers into this study. Recruitment took nearly two years and it was especially hard to recruit the non-Hispanic White caregivers. Perhaps as a function of having to rely on a sample of convenience, the final sample consisted of low and unequal numbers of ethnic caregivers and a disproportionate number of female caregivers. The sample was also relatively young compared with previous caregiving studies. These factors taken together not only impacted the results derived from the study but signal the need to use caution in extrapolating or generalizing from the findings. It could also be that the recruitment of caregivers from support groups and referrals may lead to a sample of caregivers who are less burdened and coping more 
effectively over all. This involvement in a supportive context may affect caregivers' outcomes by moderating their perceived levels of burden and life satisfaction. In addition to the ample resources available to caregivers in South Florida, there may be a significant difference in the socioeconomic status of Hispanic caregivers in the present study as opposed to caregivers in others parts of the country. More specifically, Hispanic caregivers in South Florida may have a higher socioeconomic status than Hispanic caregivers in other areas. Thus, the nature of the convenience sample suggests the need for caution in interpreting the results. Additionally, a limitation of the study is that it did not take into account the type of disease the care-recipient had, the level of dysfunction and type of caregiving required, or the amount of time the caregiver had been in that role. All these factors have been found to relate to the amount of distress and burden that caregivers experience (Hooker, et al., 1994; Hooker, et al., 2000; Hooker et al., 1998). Although all caregivers were required to have been caring for a loved one for over a year, the cumulative effects of caregiving after one year may not be similar to that of caregiving after five years. And thus, a final caveat to consider is the fact that this research was cross-sectional in nature and thus the ongoing and cumulative effects of the caregiving experience could not be examined. In essence, this research presents a snapshot of the caregiving experience among a self-selecting sample of caregivers at one point in time. Given the dynamic and transitory nature of giving care to a loved one with a debilitating chronic illness, this snap-shot does not really reflect the totality of the caregiving experience. 


\section{Potential Implications}

Nevertheless, the present study provides useful information on specific factors such as gender and ethnicity and how they relate to the use of different coping strategies within the context of caregiving in later life. The findings show that certain caregivers could benefit from learning more effective coping strategies to lessen their burden and improve their life satisfaction. The findings showed that certain methods of coping can lead to higher levels of depression, anxiety, and caregiver burden, as well as lower levels of life satisfaction. Knowledge of specific strategies that relate to better mental health outcomes can inform and shape psychosocial interventions aimed at caregivers by training and facilitating the use of adaptive coping to reduce negative outcomes and improve life satisfaction. Psychoeducational interventions focusing on the importance of employing adaptive coping methods and refraining from turning to maladaptive coping styles may be an asset to the interventions available for therapists working with this population.

In any research study the limitations may give rise to further investigation of important questions. From the current findings it would be useful for future research to investigate the cumulative effects of caregiving. Findings here suggest the need for longitudinal studies to better examine how demographics, coping, and caregiver outcomes interact over time. Moreover, a greater and more in depth analysis of the social and familial networks of ethnically diverse caregivers is very important. Clearly, ethnic difference exist in the experience of caregiving however we do not have a clear picture of what factors within different ethnic contexts may lead to better or more effective coping for caregivers. For example, is the higher life satisfaction that was found in Hispanics 
due to decreased burden because of greater social support or greater involvement by others in the family system? Ultimately, this study has created several questions that future researchers may seek to answer.

In conclusion, the present study has highlighted points of interventions for therapists who seek to increase levels of life satisfaction and decrease levels of burden in caregivers. The effects of certain coping skills were reported in efforts to guide interventions aimed at improving the quality of coping methods employed by caregivers. Furthermore, this study has added to the literature by not only discussing the effects of demographics and coping on caregiver outcome, but also by expanding the opportunities for future research. 
Table 1

Correlations among Coping Methods and Outcomes

\begin{tabular}{|c|c|c|c|c|c|c|}
\hline Coping Methods & & Depression & State Anxiety & Trait Anxiety & $\begin{array}{c}\text { Life } \\
\text { Satisfaction }\end{array}$ & $\begin{array}{l}\text { Caregiver } \\
\text { Burden }\end{array}$ \\
\hline \multirow{2}{*}{$\begin{array}{l}\text { Positive } \\
\text { Reinterpretation } \\
\text { and Growth }\end{array}$} & Pearson & -.062 & $-.273^{* *}$ & $-.210^{*}$ & .155 & -.059 \\
\hline & $\begin{array}{l}\text { Correlation } \\
\text { Sig. } \\
\text { (2-tailed) }\end{array}$ & .536 & .005 & .033 & .117 & .555 \\
\hline \multirow{2}{*}{$\begin{array}{l}\text { Mental } \\
\text { Disengagement }\end{array}$} & Pearson & $.382 * *$ & $.298^{* *}$ & $.348^{* *}$ & -.138 & $.354^{* *}$ \\
\hline & $\begin{array}{l}\text { Correlation } \\
\text { Sig. } \\
\text { (2-tailed) }\end{array}$ & .000 & .002 & .000 & .164 & .000 \\
\hline \multirow[t]{2}{*}{$\begin{array}{l}\text { Focus On } \\
\text { Venting }\end{array}$} & $\begin{array}{l}\text { Pearson } \\
\text { Correlation }\end{array}$ & $.346^{* *}$ & .166 & $.418^{* *}$ & -.192 & $.439^{* * *}$ \\
\hline & $\begin{array}{l}\text { Sig. } \\
\text { (2-tailed) }\end{array}$ & .000 & .094 & .000 & .052 & .000 \\
\hline $\begin{array}{l}\text { Use of } \\
\text { Instructional }\end{array}$ & $\begin{array}{l}\text { Pearson } \\
\text { Correlation }\end{array}$ & -.004 & -.120 & -.048 & -.002 & .187 \\
\hline Social Support & $\begin{array}{l}\text { Sig. } \\
\text { (2-tailed) }\end{array}$ & .971 & .227 & .632 & .983 & .058 \\
\hline
\end{tabular}




\begin{tabular}{|c|c|c|c|c|c|c|}
\hline \multirow[t]{2}{*}{ Active Coping } & $\begin{array}{l}\text { Pearson } \\
\text { Correlation }\end{array}$ & $-.227^{* *}$ & $-.249^{*}$ & -.140 & .151 & $-.201^{*}$ \\
\hline & $\begin{array}{l}\text { Sig. } \\
\text { (2-tailed) }\end{array}$ & .021 & .011 & .159 & .128 & .041 \\
\hline \multirow[t]{2}{*}{ Denial } & $\begin{array}{l}\text { Pearson } \\
\text { Correlation }\end{array}$ & $.411^{* *}$ & $.302^{* *}$ & $.196^{*}$ & .132 & .140 \\
\hline & $\begin{array}{l}\text { Sig. } \\
\text { (2-tailed) }\end{array}$ & . 000 & .002 & .047 & .183 & . 158 \\
\hline \multirow{2}{*}{$\begin{array}{l}\text { Religious } \\
\text { Coping }\end{array}$} & Pearson & .028 & .131 & .026 & .033 & .162 \\
\hline & $\begin{array}{l}\text { Correlation } \\
\text { Sig. } \\
\text { (2-tailed) }\end{array}$ & .781 & . 186 & .795 & .741 & . 103 \\
\hline \multirow[t]{2}{*}{ Humor } & $\begin{array}{l}\text { Pearson } \\
\text { Correlation }\end{array}$ & .121 & -.090 & -.049 & $.229^{*}$ & $-.212^{*}$ \\
\hline & $\begin{array}{l}\text { Sig. } \\
\text { (2-tailed) }\end{array}$ & .224 & .363 & .626 & .020 & .031 \\
\hline \multirow[t]{2}{*}{$\begin{array}{l}\text { Behavioral } \\
\text { Disengagement }\end{array}$} & $\begin{array}{l}\text { Pearson } \\
\text { Correlation }\end{array}$ & $.398^{* *}$ & $.354^{* *}$ & $.321^{* *}$ & -.134 & $.315^{* *}$ \\
\hline & $\begin{array}{l}\text { Sig. } \\
\text { (2-tailed) }\end{array}$ & .000 & .000 & .001 & .177 & .001 \\
\hline \multirow[t]{2}{*}{ Restraint } & $\begin{array}{l}\text { Pearson } \\
\text { Correlation }\end{array}$ & .184 & .107 & .192 & -.102 & $.305^{* *}$ \\
\hline & $\begin{array}{l}\text { Sig. } \\
\text { (2-tailed) }\end{array}$ & .063 & .280 & .052 & .305 & .002 \\
\hline
\end{tabular}




\begin{tabular}{|c|c|c|c|c|c|c|}
\hline Use of & Pearson & -.047 & -.135 & -.068 & .044 & $.202^{*}$ \\
\hline Emotional & Correlation & & & & & \\
\hline Support & $\begin{array}{l}\text { Sig. } \\
\text { (2-tailed) }\end{array}$ & .640 & .172 & 493 & .660 & .041 \\
\hline \multirow[t]{2}{*}{ Substance Use } & $\begin{array}{l}\text { Pearson } \\
\text { Correlation }\end{array}$ & .052 & .073 & .045 & .133 & -.083 \\
\hline & $\begin{array}{l}\text { Sig. } \\
\text { (2-tailed) }\end{array}$ & .605 & .464 & .653 & .180 & .402 \\
\hline \multirow[t]{2}{*}{ Acceptance } & $\begin{array}{l}\text { Pearson } \\
\text { Correlation }\end{array}$ & $-.301^{* *}$ & $-.326^{* *}$ & $-.209^{*}$ & .099 & $-.207^{*}$ \\
\hline & $\begin{array}{l}\text { Sig. } \\
\text { (2-tailed) }\end{array}$ & .002 & .001 & .034 & .318 & .036 \\
\hline $\begin{array}{l}\text { Suppression of } \\
\text { Competing }\end{array}$ & $\begin{array}{l}\text { Pearson } \\
\text { Correlation }\end{array}$ & .152 & .007 & .100 & -.073 & .069 \\
\hline Activities & $\begin{array}{l}\text { Sig. } \\
\text { (2-tailed) }\end{array}$ & .126 & .942 & .315 & .463 & .490 \\
\hline \multirow[t]{2}{*}{ Planning } & $\begin{array}{l}\text { Pearson } \\
\text { Correlation }\end{array}$ & -.081 & -.164 & -.035 & .013 & -.060 \\
\hline & $\begin{array}{l}\text { Sig. } \\
\text { (2-tailed) }\end{array}$ & .413 & .098 & .729 & .899 & .547 \\
\hline
\end{tabular}

**. Correlation is significant at the 0.01 level (2-tailed).

*. Correlation is significant at the 0.05 level (2-tailed). 
Table 2

Results of Independent Sample t-Tests for Gender and Coping

\begin{tabular}{ccccc}
\hline Outcome & $\begin{array}{c}\text { Male Caregivers } \\
M(S D)\end{array}$ & $\begin{array}{c}\text { Female Caregivers } \\
M(S D)\end{array}$ & $t$ & $p$ \\
\hline $\begin{array}{c}\text { Use of } \\
\text { Instrumental }\end{array}$ & $7.94(3.54)$ & $10.37(3.54)$ & $t(101)=-2.58$ & $.011^{*}$ \\
$\begin{array}{c}\text { Social Support } \\
\text { Religious } \\
\text { Coping }\end{array}$ & $8.59(4.62)$ & $12.26(4.11)$ & $t(101)=-3.291$ & $.001 * *$ \\
$\quad$ Use of & & & \\
Emotional \\
Support
\end{tabular}

**. Significant at the 0.01 level

*. Significant at the 0.05 level 
Table 3

Results of Independent Sample t-Tests for Ethnicity and Coping

\begin{tabular}{ccccc}
\hline Outcome & $\begin{array}{c}\text { Hispanic } \\
\text { Caregivers } \\
M(S D)\end{array}$ & $\begin{array}{c}\text { Non-Hispanic } \\
\text { White Caregivers } \\
M(S D)\end{array}$ & $t$ & $p$ \\
\hline $\begin{array}{c}\text { Positive } \\
\text { Reinterpretation } \\
\text { and Growth }\end{array}$ & $13.20(2.10)$ & $11.79(3.10)$ & $t(101)=2.668$ & $.009^{* *}$ \\
Denial & $6.33(3.09)$ & $4.83(1.26)$ & $t(101)=3.270$ & $.002^{* *}$ \\
$\begin{array}{c}\text { Religious } \\
\text { Coping }\end{array}$ & $12.94(3.38)$ & $10.22(4.95)$ & $t(101)=3.224$ & $.002^{* *}$ \\
Humor & $10.13(4.36)$ & $6.12(3.09)$ & $t(101)=5.420$ & $.0001^{* *}$ \\
& & & \\
Acceptance & $12.27(3.29)$ & $13.52(2.85)$ & $t(101)=-2.071$ & $.041^{*}$ \\
$\begin{array}{c}\text { Use of } \\
\text { Emotional } \\
\text { Support }\end{array}$ & $8.98(2.91)$ & $10.18(3.29)$ & $t(101)=-1.751$ & .083 \\
\hline
\end{tabular}

**. Significant at the 0.01 level

*. Significant at the 0.05 level 
Table 4

Correlations among Familism, Filial Piety and Outcomes

\begin{tabular}{|c|c|c|c|c|c|c|c|c|c|}
\hline Variables & & Familism & $\begin{array}{l}\text { Filial } \\
\text { Piety }\end{array}$ & $\begin{array}{l}\text { Adaptive } \\
\text { Coping }\end{array}$ & $\begin{array}{c}\text { Maladaptive } \\
\text { Coping }\end{array}$ & Depression & $\begin{array}{c}\text { State } \\
\text { Anxiety }\end{array}$ & $\begin{array}{c}\text { Trait } \\
\text { Anxiety }\end{array}$ & $\begin{array}{c}\text { Life } \\
\text { Satisfaction } \\
\end{array}$ \\
\hline \multirow[t]{3}{*}{ Filial Piety } & $\begin{array}{l}\text { Pearson } \\
\text { Correlation }\end{array}$ & $.417^{* *}$ & & & & & & & \\
\hline & $\begin{array}{l}\text { Sig. } \\
\text { (2-tailed) }\end{array}$ & .000 & & & & & & & \\
\hline & $\mathrm{N}$ & 103 & & & & & & & \\
\hline \multirow{4}{*}{$\begin{array}{l}\text { Adaptive } \\
\text { Coping }\end{array}$} & Pearson & .105 & .012 & & & & & & \\
\hline & Correlation & & & & & & & & \\
\hline & $\begin{array}{l}\text { Sig. } \\
\text { (2-tailed) }\end{array}$ & .291 & .908 & & & & & & \\
\hline & $\mathrm{N}$ & 103 & 103 & & & & & & \\
\hline \multirow{4}{*}{$\begin{array}{l}\text { Maladaptive } \\
\text { Coping }\end{array}$} & Pearson & .004 & $.201^{*}$ & .187 & & & & & \\
\hline & Correlation & & & & & & & & \\
\hline & $\begin{array}{l}\text { Sig. } \\
\text { (2-tailed) }\end{array}$ & .969 & .041 & .059 & & & & & \\
\hline & $\mathrm{N}$ & 103 & 103 & 103 & & & & & \\
\hline \multirow[t]{3}{*}{ Depression } & $\begin{array}{l}\text { Pearson } \\
\text { Correlation }\end{array}$ & -.058 & .088 & -.027 & $.515^{*}$ & & & & \\
\hline & $\begin{array}{l}\text { Sig. } \\
\text { (2-tailed) }\end{array}$ & .559 & .378 & .784 & .000 & & & & \\
\hline & $\mathrm{N}$ & 103 & 103 & 103 & 103 & & & & \\
\hline
\end{tabular}




\begin{tabular}{|c|c|c|c|c|c|c|c|c|c|}
\hline \multirow{4}{*}{$\begin{array}{l}\text { State } \\
\text { Anxiety }\end{array}$} & Pearson & -.099 & .125 & -.177 & $.375^{* *}$ & $.510 * *$ & & & \\
\hline & Correlation & & & & & & & & \\
\hline & $\begin{array}{l}\text { Sig. } \\
\text { (2-tailed) }\end{array}$ & .319 & .207 & .074 & .000 & .000 & & & \\
\hline & $\mathrm{N}$ & 103 & 103 & 103 & 103 & 103 & & & \\
\hline \multirow{4}{*}{$\begin{array}{l}\text { Trait } \\
\text { Anxiety }\end{array}$} & Pearson & $-.226^{*}$ & .149 & -.076 & $.437^{* *}$ & $.698 * *$ & $.562 * *$ & & \\
\hline & Correlation & & & & & & & & \\
\hline & $\begin{array}{l}\text { Sig. } \\
\text { (2-tailed) }\end{array}$ & .022 & .133 & .446 & .000 & .000 & .000 & & \\
\hline & $\mathrm{N}$ & 103 & 103 & 103 & 103 & 103 & 103 & & \\
\hline \multirow{4}{*}{$\begin{array}{l}\text { Life } \\
\text { Satisfaction }\end{array}$} & Pearson & $.202^{*}$ & .068 & .106 & -.082 & $-.306^{* *}$ & $-.400 * *$ & $-.603 * *$ & \\
\hline & Correlation & & & & & & & & \\
\hline & $\begin{array}{l}\text { Sig. } \\
\text { (2-tailed) }\end{array}$ & .041 & .493 & .285 & .408 & .002 & .000 & .000 & \\
\hline & $\mathrm{N}$ & 103 & 103 & 103 & 103 & 103 & 103 & 103 & \\
\hline \multirow{4}{*}{$\begin{array}{l}\text { Caregiver } \\
\text { Burden }\end{array}$} & Pearson & $-.233^{*}$ & -.001 & .043 & $.399^{* *}$ & $.518^{* *}$ & $.419^{* *}$ & $.533^{* *}$ & $-.506 * *$ \\
\hline & Correlation & & & & & & & & \\
\hline & $\begin{array}{l}\text { Sig. } \\
\text { (2-tailed) }\end{array}$ & .018 & .995 & .668 & .000 & .000 & .000 & .000 & .000 \\
\hline & $\mathrm{N}$ & 103 & 103 & 103 & 103 & 103 & 103 & 103 & 103 \\
\hline
\end{tabular}




\section{References}

Adams, B., Aranda, M. P., Kemp, B., \& Takagi, K. (2002). Ethnic and Gender Differences in Distress Among Anglo American, African American, Japanese American, and Mexican American Spousal Caregivers of Persons With Dementia. Journal of Clinical Geropsychology, 8(4), 279-301.

Agren, M. (1998). Life at 85 and 92: A qualitative longitudinal study of how the oldest of old experience and adjust to the increasing uncertainty of existence. International Journal of Aging and Human Development , 47, 105-117.

Aldwin, C. M., Sutton, K. J., Chiara, G., \& Spiro, III, A. (1996). Age differences in stress, coping, and appraisal: Findings from the Normative Aging Study. Journal of Gerontology, 51B(4), 179-188.

Anngela-Cole, L., \& Hilton, J. M. (2009). The role of attitudes and culture in family caregiving for older adults. Home Health Care Services Quarterly, 28, 59-83.

Arango-Lasprilla, J. C., Olivera Plaza, S. L., Drew, A., Perdomo Romero, J. L., Arango Pizarro, J. A., Francis, K., \& Kreutzer, J. (2010). Family needs and psychosocial functioning of caregivers of individuals with spinal cord injury from Colombia, South America. NeuroRehabilitation, 27, 83-93.

Asai, M. (2002). Sekentei and family caregiving of elders among Japanese:Development and evaluation of the sekentei scale (Unpublished doctoral dissertation). University of Hawaii-Honolulu.

Baker, K. L., \& Robertson, N. (2008). Coping with caring for someone with dementia: Reviewing the literature about men. Aging \& Mental Health, 12(4), 413-422.

Barber, C. E. (2002). A comparison of Hispanic and non-Hispanic White families caring for elderly patients. Paper presented at the 55th Annual Meeting of the Gerontological Society of America, Boston, MA.

Bardis, P. D. (1959). A familism scale. Marriage \& Family Living, 21, 340-341.

Barusch, A. A., \& Spaid, W. M. (1991). Reducing caregiver burden through short-term training: Evaluation findings from a caregiver support project. Journal of Gerontological Social Work, 17(1), 7-33.

Birkeland, A., \& Natvig, G. K. (2009). Coping with ageing and failing health: A qualitative study among elderly living alone. International Journal of Nursing Practice, 15, 257-264. 
Bonebright, C. A., Clay, D. L., \& Ankenmann, R. D. (2000). The relationship of workaholism with work-life conflict, life satisfaction, and purpose in life. Journal of Counseling Psychology, 47(4), 469-477.

Borg, C., \& Hallberg, I. R. (2006). Life satisfaction among informal caregivers in comparison with non-caregivers. Scand J Caring Sci, 20, 427-438.

Brändtstadter, J., \& Renner, G. (1990). Tenacious goal pursuit and felxible goal adjustment: Explication and age related analysis of assimilative and accomodative strategies of coping. Psychology and Aging, 5, 58-67.

Brändtstadter, J., Rothermund, K., \& Schmitz, U. (1997). Coping resources in later life. Revue Europeenne de Psychologie Appliquee, 47, 107-114.

Brändtstadter, J., Wentura, D., \& Greve, W. (1993). Adaptive resources of the aging self: Outlines of an emergent perspective. International Journal of Behavioral Development, 16, 323-349.

Campbell, A., Converse, P. E., \& Rodgers, W. L. (1976). The Quality of American Life. New York: Russell Sage Foundation.

Carver, C. S. (1997). You want to measure coping but your protocol's too long: Consider the brief COPE. Journal of Behavioral Medicine, 4(1), 92-100.

Carver, C. S., Scheier, M. F., \& Weintraub, J. K. (1989). Assessing coping strategies: A theoretically based approach. Journal of Personality and Social Psychology, 56, 267-283.

Caspi, A., \& Elder, Jr., G. H. (1986). Life satisfaction in old age: Linking social psychology and history. Journal of Psychology and Aging, 1(1), 18-26.

Chakrabarti, S., \& Gill, S. (2002). Coping and its correlates among caregivers of patients with Bipolar disorder: A preliminary study. Bipolar Disorders, 4, 50-60.

Chamberlain, K. (1988). On the structure of well being. Social Indicators Research, 20, 581-604.

Chang, B., Noonan, A. E., \& Tennstedt, S. L. (1998). The role of religion/spirituality in coping with caregiving for disabled elders. The Gerontological Society of America, 38(4), 463-470.

Cheng, C. (2001). Assessing coping flexibility in real-life and laboratory settings: A multimethod approach. Journal of Personality and Social Psychology, 80, 814833. 
Cheng, C., \& Cheung, M. W. (2005). Cognitive processes underlying coping flexibility: Differentiation and integration. Journal of Personality, 73, 859-886.

Choo, W., Low, W., Karina, R., Poi, P. J., Ebenezer, E., \& Prince, M. J. (2003). Social support and burden among caregivers of patients with dementia in Malaysia. AsiaPacific Journal of Public Health, 15(1), 23-29.

Collins, C., \& Jones, R. (1997). Emotional distress and morbidity in Dementia carers: A matched comparison of husbands and wives. International Journal of Geriatric Psychiatry, 12, 1168-1173.

Cox, C., \& Monk, A. (1990). Minority caregivers of dementia victims: A comparison of Black and Hispanic families. Journal of Applied Gerontology, 9, 340-354.

Diener, E. (1984). Subjective well being. Psychological Bulletin, 95(3), 542-575.

Diener, E., Emmons, R. A., Larsen, R. J., \& Griffin, S. (1985). The satisfaction with life scale. Journal of Personality Assessment, 49(1), 71-75.

Diener, E., Suh, E. M., Lucas, R. E., \& Smith, H. L. (1999). Subjective well-being: Three decades of progress. Psychol Bull, 125, 276-302.

Endler, N. S., \& Parker, J. D. (1990). Multidimensional assessment of coping: A critical evaluation. Journal of Personality and Social Psychology, 58, 844-854.

Essex, E. L., Seltzer, M. M., \& Krauss, M. W. (1999). Differences in coping effectiveness and well-being among aging mothers and fathers of adults with mental retardation. American Journal on Mental Retardation, 104(6), 545-563.

Fiksenbaum, L. M., Greenglass, E. R., \& Eaton, J. (2006). Perceived Social Support, Hassles, and Coping Among the Elderly. The Journal of Applied Gerontology, 25(1), 17-30.

Fitting, M., Rabins, P., Lucas, M. J., \& Eastham, J. (1986). Caregivers for dementia patients: A comparison of husbands and wives. Gerontologist, 26, 248-252.

Folkman, S. (1984). Personal control and stress and coping strategies: A theoretical analysis. Journal of Personality and Social Psychology, 46(), 839-852.

Folkman, S., \& Lazarus, R. S. (1980). An analysis of coping in a middleaged community sample. Journal of Health and Social Behavior, 21, 219-239.

Folkman, S., Lazarus, R. S., Pimley, S., \& Novacek, J. (1987). Age Differences in Stress and Coping Processes. Psychology and Aging, 2(2), 171-184. 
Folstein, M. F., Folstein, S. E., \& McHugh, P. R. (1975). "Mini-mental state" : A practical method for grading the cognitive state of patients for the clinician. Journal of Psychiatric Research, 12(3), 189-198.

Frazier, L. D. (2000). Coping with disease-related stressors in Parkinson's disease . The Gerontologist, 40(1), 53-63.

Galanti, G. (2003). The hispanic family and male-female relationships: An overview. $J$ Transcult Nurs, 14(3), 180-185.

George, L. K., \& Gwyther, L. P. (1986). Caregiver wellbeing: A multidimensional examination of family caregivers of demented adults. Gerontologist, 26, 253-269.

Gerhart, B. (1987). How important are dispositional factors as determinants of job satisfaction? Implications for job design and other personnel programs. Journal of Applied Psychology, 72(3), 366-373.

Grandon, P., Jenaro, C., \& Lemus, S. (2008). Primary caregivers of schizophrenia outpatients: Burden and predictor variables. Psychiatry Research, 158, 335-343.

Greer, T. M., \& Brown, P. (2011). Minority status stress and coping processes among African American college students. Journal of Diversity in Higher Education, 4(1), 26-38.

Greer, T. M., \& Chwalisz, K. (2007). Minority-related stressors and coping process among African American college students. Journal of College Student Development, 48(4), 388-404.

Griffin, J., \& McKenna, K. (1998). Influences on leisure and life satisfaction of elderly people. Physical \& Occupational Therapy in Geriatrics, 15(4), 1-16.

Guarnaccia, P. J., \& Parra, P. (1996). Ethnicity, social status, and families' experiences of caring for a mentally ill family member. Community Mental Health Journal, 32, 243-260.

Gueritalt-Chalvin, V., Kalichman, S. C., Demi, A., \& Peterson, J. L. (2000). Workrelated stress and occupational burnout in AIDS caregivers: Test of a coping model with nurses providing AIDS care. AIDS Care, 12(2), 149-161.

Haley, W. E., LaMonde, L. A., Han, B., Burton, A. M., \& Schonwetter, R. (2003). Predictors of depression and life satisfaction among spousal caregivers in hospice: Application of a Stress Process Model. Journal of Palliative Medicine, 6(2), 215224. 
Haley, W. E., LaMonde, L. A., Han, B., Narramore, S., \& Schonwetter, R. (2001). Family caregiving in hospice: Effects of psychological and health functioning among spousal caregivers of hospice patients with lung cancer or dementia . Hosp $J, 15,1-18$.

Haley, W. E., Roth, D. L., Coleton, M. I., Ford, G. R., West, C. A., Collins, R. P., \& Isobe, T. L. (1996). Appraisal, coping, and social support as mediators of wellbeing in Black and White family caregivers of patients with Alzheimer's disease. Journal of Consulting and Clinical Psychology, 64, 121-129.

Haley, W. E., Wadley, V. G., West, C. C., \& Vetzel, L. L. (1994). How caregiving stressors change with severity of dementia. Seminars in Speech and Language, $15,195-205$.

Haley, W. E., West, C. A., Wadley, V. G., Ford, G. R., White, F. A., Barrett, J. J., \& Roth, D. L. (1995). Psychological, social, and health impact of caregiving: A comparison of black and white dementia family caregivers and noncaregivers. Psychology and Aging, 10, 540-552.

Hamarat, E., Thompson, D., Steele, D., Matheny, K., \& Simons, C. (2002). Age differences in coping resources and satisfaction with life among middle-aged, young-old and oldest-old adults. The Journal of Genetic Psychology, 163(3), 360367.

Hansen, T., Salgsvold, B., \& Moum, T. (2008). Financial satisfaction in old age: A satisfaction paradox a result of accumulated wealth?. Soc Indic Res, 89, 323-347.

Hayden, M. F., \& Heller, T. (1997). Support, problem-solving/coping ability, and personal burden of younger and older caregivers of adults with mental retardation. Mental Retardation, 35(5), 364-372.

Hinrichsen, G. A., Hernandez, N. A., \& Pollack, S. (1992). Difficulties and rewards of family care of the depressed older adult. Gerontologist, 32, 486-492

Ho, C. J., Weitzman, P. F., Xingjia, C., \& Levkoff, S. E. (2000). Stress and service use among minority caregivers to elders with dementia. Journal of Gerontological Social Work, 33(1), 67-88.

Ho, D. Y. (1994). Filial piety, authoritarian moralism and cognitive conservatism in Chinese societies. Genetic, Social, and General Psychology Monographs, 120(3), $349-365$.

Holmbeck, G. N. (2006, October 04). Testing for mediation and moderation. Retrieved from http://www.4researchers.org/articles/370 
Hooker, K., Frazier, L. D., \& Monahan, D. J. (1994). Personality and coping among caregivers of spouses with Dementia. The Gerontologist, 34(3), 386-392.

Hooker, K., Manoogian-O’Dell, M., Monahan, D. J., Frazier, L. D., \& Shifren, K. (2000). Does type of disease matter? Gender differences among Alzheimer's and Parkinson's disease spouse caregivers. The Gerontologist, 40(5), 568-573.

Hooker, K., Monahan, D. J., Bowman, S. R., Frazier, L. D., \& Shifren, K. (1998). Personality counts for a lot: Predictors of mental and health of spouse caregivers in two disease groups. Journal of Gerontology, 53B(2), 73-85.

Jang, Y., Chiriboga, D. A., Kim, G., \& Phillips, K. (2008). Depressive symptoms in four racial and ethnic groups. The survey of older Floridians (SOF). Research on Aging, 30(4), 488-502.

Kim, J. H., \& Knight, B. G. (2008). Effects of caregiver status, coping styles, and social support on the physical health of Korean American caregivers. The Gerontologist, 48(3), 287-299.

Kim, J. H., Knight, B. G., \& Flynn Longmire, C. V. (2007). The Role of Familism in Stress and Coping Processes Among African American and White Dementia Caregivers: Effects on Mental and Physical Health . Health Psychology, 26(5), 564-576.

Knight, B. G., \& McCallum, T. J. (1998). Heart rate reactivity and depression in AfricanAmerican and white dementia caregivers: Reporting bias or positive coping? Aging and Mental Health, 2, 212-221.

Kosberg, J. I., Kaufman, A. V., Burgio, L. D., Leeper, J. D., \& Sun, F. (2007). Family caregiving to those with Dementia in rural Alabama. Journal of Aging and Health, 19(1), 3-21.

Kraemer, H. C., Kiernan, M., Essex, M., \& Kupfer, D. J. (2008). How and why criteria defining moderators and mediators differ between the Baron \& Kenny and MacArthur approaches. Health Psychol, 27(2), 101-108.

Kristensson Ekwall, A., \& Rahm Hallberg, I. (2006). The association between caregiving satisfaction, difficulties and coping among older family caregivers. Journal of Clinical Nursing, 16, 832-844.

Landry-Meyer, L., Gerard, J. M., \& Guzell, J. R. (2005). Caregiving stress among grandparent raising grandchildren: The functional role of social support. Marriage \& Family Review, 37(1/2), 171-190. 
Lawrence, R. H., Tennstedt, S. L., \& Assman, S. F. (1998). Quality of the caregiver-care recipient relationship: Does it offset negative consequences of caregiving for family caregivers? Psychology and Aging, 13(1), 150-158.

Lawton, M. P., Moss, M., Kleban, M. H., Glicksman, A., \& Rovine, M. (1991). A twofactor model of caregiving appraisal and psychological well-being. Journal of Gerontology, 46, P181-P189.

Lawton, M. P., Rajagopal, D., Brody, E., \& Kleban, M. H. (1992). The dynamics of caregiving for a demented elder among Black and White families. Journal of Gerontology, 47, S156-S164.

Lazarus, R. S., \& Folkman, S. (1984). Stress, appraisal, and coping. New York: Springer.

Lee, Y. R., \& Sung, K. T. (1998). Cultural influences on caregiving burden: Cases of Koreans and Americans. International Journal of Aging and Human Development, 46, 125-141.

Lewinsohn, P., Redner, J. E., \& Seeley, J. R. (1991). The relationship between life satisfaction and psychosocial variables: New perspectives. In F. Strack, M. Argyle, \& N. Schwarz (Eds.), Subjective well-being An interdisciplinary perspective (pp. 141-169). Oxford, England: Pergamon Press plc.

Losada, A., Knight, B. G., Marquez-Gonzalez, M., Montorio, I., Etxeberria, I., \& Penacoba, C. (2008). Confirmatory factor analysis of the familism scale in a sample of dementia caregivers. Aging \& Mental Health, 12(4), 504-508.

Lutzky, S. M., \& Knight, B. G. (1994). Explaining Gender Differences in Caregiver Distress: The Roles of Emotional Attentiveness and Coping Styles. Psychology and Aging, 9(4), 513-519.

Mallard, A. G., Lance, C. E., \& Michalos, A. C. (1997). Culture as a moderator of overall life satisfaction - Life facet satisfaction relationships. Social Indicators Research, 40, 259-284.

Matud, M. P. (2004). Gender differences in stress and coping styles. Personality and Individual Differences, 37, 1401-1415.

McCabe, K. M., Yeh, M., Lau, A., Garland, A., \& Hough, R. (2003). Racial/Ethnic differences in caregiver strain and perceived social support among parents of youth with emotional and behavioral problems. Mental Health Services Research, $5(3), 137-147$. 
McCallum, T. J., Longmire, C. F., \& Knight, B. G. (2007). African American and White female caregivers and the Sociocultural Stress and Coping Model. Clinical Gerontologist, 30(4), 25-37.

McClendon, M. J., Smyth, K. A., \& Neundorfer, M. M. (2004). Survival of persons With Alzheimer's disease: Caregiver coping matters. The Gerontologist, 44(4), 509519.

Meadow, H. L., Mentzer, J. T., Rahtz, D. R., \& Sirgy, M. J. (1992). A life satisfaction measure based on judgment theory. Social Indicators Research, 26, 23-59.

Michalos, A. C. (1986). An application of Multiple Discrepancies Theory (MDT) to seniors. Social Indicators Research, 18, 349-373.

Minnes, P., Woodford, L., \& Passey, J. (2007). Mediators of well-being in ageing family carers of adults with intellectual disabilities. Journal of Applied Research in Intellectual Disabilities, 20, 539-552.

Montoro-Rodriguez, J., \& Gallagher-Thompson, D. (2009). The role of resources and appraisals in predicting burden among Latina and non-Hispanic white female caregivers: A test of an expanded socio-cultural model of stress and coping. Aging \& Mental Health, 13(5), 648-658.

Morano, C. (2003). The role of appraisal and expressive support in mediating strain and gain in Hispanic Alzheimer's disease caregivers. Journal of Ethnic is Cultural Diversity in Social Work, 12(2), 1-18.

Morano, C. L., \& King, D. (2005). Religiosity as a mediator of caregiver well-being: Does ethnicity make a difference? Journal of Gerontological Social Work, 45(1/2), 69-84.

Navaie-Waliser, M., Feldman, P. H., Gould, D. A., Levine, C., Kuerbis, A. N., \& Donelan, K. (2001). The experiences and challenges of informal caregivers: Common themes and differences among Whites, Blacks, and Hispanics. The Gerontologist, 41, 733-741.

Navaie-Waliser, M., Spriggs, A., \& Feldman, P. H. (2002). Informal caregiving differential experiences by gender . Medical Care, 40(12), 1249-1259.

Neal, M. B., Ingerson-Dayton, B., \& Starrels, M. E. (1997). Gender and relationship differences in caregiver patterns and consequences among employed caregivers. Gerontologist, 37, 804-916.

Neugarten, B. L., Havighurst, R. J., \& Tobin, S. S. (1961). The measurement of life satisfaction. Journal of Gerontology, 16, 134-143. 
Outten, H. R., Schmitt, M. T., Garcia, D. M., \& Branscombe, N. R. (2009). Coping options: Missing links between minority group identification and psychological well being. Applied Psychology: An International Review, 58(1), 146-170.

Pasupuleti, S., Allen, R. I., Lambert, E. G., \& Cluse-Tolar, T. (2009). The impact of work stressors on the life satisfaction of social service workers: A preliminary study. Administration in Social Work, 33, 319-339.

Pavot, W., \& Diener, E. (1993). Review of the Satisfaction with Life Scale. Psychological Assessment, 5(2), 164-172.

Pinquart, M., \& Sorensen, S. (2005). Ethnic differences in stressors, resources, and psychological outcomes of family caregiving: A meta-analysis. The Gerontologist, 45(1), 90-106.

Ptacek, J. T., Smith, R. E., \& Dodge, K. L. (1994). Gender Differences in Coping with Stress: When Stressor and Appraisals Do Not Differ. Pers Soc Psychol Bull, 20, 420-430.

Quayhagen, M. P., \& Quayhagen, M. (1988). Alzheimer's stress: Coping with the caregiving role. The Gerontological Society of America, 28(3), 391-396.

Raschick, M., \& Ingersoll-Dayton, B. (2004). The costs and rewards of caregiving among aging spouses and adult children. Family Relations, 53(3), 317-325.

Ribeiro, O., \& Paul, C. (2008). Older male carers and the positive aspects of care. Ageing \& Society, 28, 165-183.

Rice, R. W., Near, J. P., \& Hunt, R. G. (1980). The job satisfaction/life satisfaction relationship: A review of the empirical research. Basic and Applied Social Psychology, 1(1), 37-64.

Roberto, K. A. (1995). Family caregivers of aging adults with disabilities: A review of the caregiving literature. In The Elderly Caregiver: Caring for Adults with Developmental Disabilities (pp. 3-18). Newbury Park, CA.: Sage Publications.

Rogers, E. M., \& Sebald, H. (1962). A distinction between familism, family integration, and kinship orientation. Marriage and Family Living, 24, 25-30.

Rose, S. K., Strauss, M. E., Neundorfer, M. M., Smyth, K. A., \& Stuckey, J. C. (1997). The relationship of self-restraint and distress to coping among spouses caring for persons with Alzheimer's disease. Journal of Applied Gerontology, 16(1), 91-103.

Roth, D. L., Haley, W. E., Owen, J. E., Clay, O. J., \& Goode, K. T. (2001). Latent growth models of the longitudinal effects of dementia caregiving: A comparison of 
African American and White family caregivers. Psychology and Aging, 16(3), 427-436.

Rozario, P. A., \& DeRienzis, D. (2008). Familism beliefs and psychological distress among African American women caregivers. The Gerontologist, 48(6), 772-780.

Saad, K., Hartman, J., Kurian, M., Graham, C., Wilcock, G., \& Ballard, C. (1995). Coping by the carers of dementia sufferers. Age and Ageing, 24, 495-498.

Sabogal, F., Marin, G., Otero-Sabogal, R., VanOss Marin, B., \& Perez-Stable, E. J. (1987). Hispanic families and acculturation: What changes and what doesn' $t$ ? Hispanic Journal of Behavioral Sciences, 9(4), 397-412.

Sander, A. M., Davis, L. C., Struchen, M. A., Atchinson, T., Sherer, M., Malec, J. F., \& Nakase-Richardson, R. (2007). Relationship of race/ethnicity to caregivers' coping, appraisals, and distress after traumatic brain injury. NeuroRehabilitation, 22, 9-17.

Schulz, R., O’Brien, A. T., Bookwala, J., \& Fleissner, K. (1995). Psychiatric and physical morbidity effects of dementia caregiving: Prevalence, correlates and causes. Gerontologist, 35, 771-791.

Shimazu, A., Shimazu, M., \& Odara, T. (2005). Divergent Effects of Active Coping on Psychological Distress in the context of the job demands-control-support model: The roles of job control and social support. International Journal of Behavioral Medicine, 12(3), 192-198.

Speilberger, C. D. (1983). Manual for the State-Trait Anxiety Inventory (Form Y). Palo Alto, CA: Consulting Psychologists Press.

Sun, F., Kosberg, J. I., Leeper, J., Kaufman, A. V., \& Burgio, L. (2010). Racial differences in perceived burden of rural Dementia caregivers. Journal of Applied Gerontology, 29(3), 290-307.

Tamres, L. K., Janicki, D., \& Hegelson, V. S. (2002). Sex Differences in Coping Behavior: A Meta-Analytic Review and an Examination of Relative Coping. Personality and Social Psychology Review, 6(1), 2-30.

Trail Ross, M. E., \& Aday, L. A. (2006). Stress and coping in African American grandparents who are raising their grandchildren. Journal of Family Issues, 27(7), 912-932.

Utsey, S. O., Ponterotto, J. G., Reynolds, A. L., \& Cancelli, A. A. (2000). Racial discrimination, coping, life satisfaction, and self-esteem among African Americans. Journal of Counseling and Development, 78, 72-80. 
Valle, R., Yamada, A. M., \& Barrio, C. (2004). Ethnic differences in social network helpseeking strategies among Latino and Euro-American dementia caregivers. Aging and Mental Health, 8(6), 535-543.

Waldron-Perrine, B., Rapport, L. J., Ryan, K. A., Telmet Harper, K., \& Fuerst, D. (2009). Predictors of life satisfaction in caregivers of persons with Multiple Sclerosis. The Clinical Neuropsychologist, 23(3), 462-478.

Wilson-Genderson, M., Pruchno, R. A., \& Cartwright, F. P. (2009). Effects of caregiver burden and satisfaction on affect of older end-stage renal disease patients and their spouses. Psychology and Aging, 24(4), 955-967.

Wykle, M., \& Segall, M. (1991). A comparison of black and white family caregivers experience with dementia. Journal of National Black Nurses' Association, 5, 2941.

Yeh, K. H., \& Bedford, O. (2003). A test of the dual filial piety model. Asian Journal of Social Psychology, 6, 215-288.

Yeh, S. J., Huang, C., Chou, H., \& Wan, T. H. (2009). Gender Differences in Stress and Coping among Elderly Patients on Hemodialysis. Sex Roles, 60, 44-56.

Zarit, S. H., Reever, K. E., \& Bach-Peterson, J. (1980). Relatives of the impaired elderly: Correlates of feelings of burden. The Gerontologist, 20(6), 649-655. 
APPENDICES 
Appendix 1 - Informed Consent 


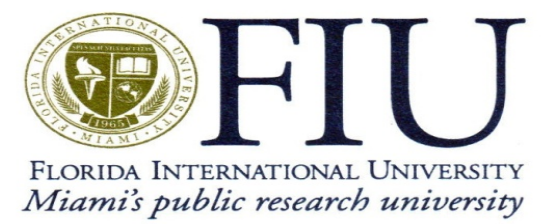

\section{ADULT CONSENT TO PARTICIPATE IN A RESEARCH STUDY Correlations among Coping Skills and Life Satisfaction in Ethnic Older Caregivers}

\section{PURPOSE OF THE STUDY}

You are being asked to participate in this research study. The purpose of this study is to look at how older caregivers from Hispanic and Non-Hispanic White ethnicities handle the stress of caring for a loved one. There is an interest in how this stress is managed because it may lead to improved or worsened life satisfaction among these caregivers. The goal is to see which methods of stress management lead to higher or lower levels of life satisfaction.

\section{NUMBER OF STUDY PARTICIPANTS}

If you decide to be in this study, you will be one of 100 people in this research study.

\section{DURATION OF THE STUDY}

Your participation will require approximately two and a half $\left(\begin{array}{ll}2 & 1 / 2\end{array}\right)$ hours.

\section{PROCEDURES}

If you agree to be in the study, you will be asked to do the following things:

1. You will be asked to participate in a face-to-face interview where your mental status will be assessed. Then you will be asked about your age, ethnicity, marital status, education level, occupation, religiosity, health, and the health of the person you care for. How you handle the stress of caring for your loved one and the level of burden you feel will also be measured. The life satisfaction you currently feel and your beliefs about obligation to your family will be assessed as well. You are encouraged to be as open and honest as possible.

\section{RISKS AND/OR DISCOMFORTS}

The following risks may be associated with your participation in this study: There are only minimal risks of emotional distress expected to be associated with your participation. 


\section{BENEFITS}

The following benefits may be associated with your participation in this study: Your participation will lead to a better understanding of how older caregivers from Hispanic and Non-Hispanic White ethnicities handle the stress of caring for a loved one and how this impacts their life satisfaction. This information may lead to improved psychological treatment for caregivers who want to begin attending therapy sessions by allowing the therapist to adjust his or her services to the needs of the specific caregiver.

\section{ALTERNATIVES}

There are no known alternatives available to you other than not taking part in this study. However, any significant new findings developed during the course of the research which may relate to your willingness to continue participation will be provided to you.

\section{CONFIDENTIALITY}

The records of this study will be kept private and will be protected to the fullest extent provided by law. In any sort of report that might be published, no information that will make it possible to identify a subject will be included. Research records will be stored securely and only the researcher team will have access to the records. However, your records may be reviewed for audit purposes by authorized University or other agents who will be bound by the same provisions of confidentiality.

\section{COMPENSATION \& COSTS}

You will not be receiving payment for your participation. You will not be responsible for any costs to participate in this study.

\section{RIGHT TO DECLINE OR WITHDRAW}

Your participation in this study is voluntary. You are free to participate in the study or withdraw your consent at any time. Your withdrawal or lack of participation will not affect any benefits to which you are otherwise entitled. The investigator reserves the right to remove you without your consent at such time that they feel it is in the best interest.

\section{RESEARCHER CONTACT INFORMATION}

If you have any questions about the purpose, procedures, or any other issues relating to this research study you may contact Didiana De La Osa at 305-878-9818, or by email at didiana.delaosa@yahoo.com. 


\section{IRB CONTACT INFORMATION}

If you would like to talk with someone about your rights of being a subject in this research study or about ethical issues with this research study, you may contact the FIU Office of Research Integrity by phone at 305-348-2494 or by email at ori@fiu.edu.

\section{PARTICIPANT AGREEMENT}

I have read the information in this consent form and agree to participate in this study. I have had a chance to ask any questions I have about this study, and they have been answered for me. I understand that I am entitled to a copy of this form after it has been read and signed.

Signature of Participant

Date

Printed Name of Participant

Signature of Person Obtaining Consent

Date 
Appendix 2 - Informed Consent in Spanish 


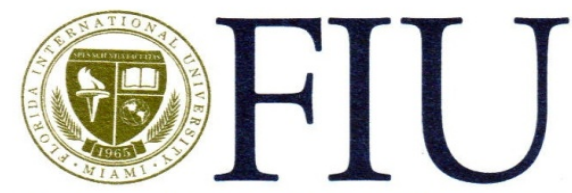

FLORIDA INTERNATIONAL UNIVERSITY

Miami's public research university

\section{CONSENTIMIENTO DE UN ADULTO PARA PARTICIPAR EN UN ESTUDIO INVESTIGATIVO.}

Correlación entre métodos de adaptación y satisfacción en la vida para personas de mayor edad y cierto grupo étnico que cuidan de otra persona.

\section{PROPÓSITO}

A usted se le pide su participación en un estudio investigativo. El propósito de este estudio es analizar cómo las personas mayores de descendencia hispana y blancos no hispanos, manejan el esfuerzo y la tensión por cuidar de un ser querido. Existe interés en cómo se maneja la tensión creada por los cuidados que se le dan a otra persona, y como estos afectan en mejorar o empeorar la satisfacción en la vida entre los responsables de cuidar a un ser querido. El objetivo es llegar a establecer los métodos para controlar la tensión que llevan a niveles altos o bajos de satisfacción en la vida.

\section{CANTIDAD DE PARTICIPANTES}

Si usted está de acuerdo en participar, será uno de 100 participantes.

\section{DURACIÓN DEL ESTUDIO}

Su participación requiere aproximadamente 2 horas y media.

\section{PROCEDIMIENTO}

Si usted decide participar, se le pedirá lo siguiente:

1. Tendrá que le pedirá participar en una entrevista cara a cara donde su estado mental será evaluado. Se le preguntará su edad, grupo étnico, estado civil, nivel de educación, ocupación, religión, salud y sobre la salud de la persona que recibe sus cuidados. Como usted maneja la tensión por ser proveedor de cuidados a un ser querido y el nivel de sobrecarga que siente también serán evaluados. La satisfacción en la vida que usted siente en este momento y lo que cree sobre su obligación a su familia serán evaluados en adición. Le pedimos su total y completa honestidad y sinceridad.

\section{RIESGOS E INCOMODIDADES}

Experimentará los siguientes riesgos, asociados con este estudio: Solo existen riesgos mínimos de angustia emocional asociadas con su participación. 


\section{BENEFICIOS}

Los siguientes beneficios pueden ser obtenidos por su participación es este estudio: Su participación puede ayudar para un mejor entendimiento de cómo las personas mayores de descendencia hispana y blancos no hispanos, manejan el esfuerzo y la tensión por cuidar de un ser querido y como impacta su satisfacción en la vida. Este estudio investigativo puede tener como consecuencia mejorías en el tratamiento psicológico de las personas que ofrecen cuidados a otros si deciden en algún momento asistir a sesiones terapéuticas, permitiendo al terapeuta ajustar sus servicios a las necesidades específicas de la persona que le da cuidados a un ser querido

\section{ALTERNATIVAS}

No se conocen alternativas que no sea negarse a participar en este estudio. No obstante, cualquier conclusión de importancia obtenida durante el estudio, que pueda tener relación con su disposición a continuar su participación, le será informada.

\section{CONFIDENCIALIDAD}

Los registros de este estudio investigativo serán privados y tendrán la máxima protección ofrecida por la ley. Aún cuando se publiquen reportes o datos, no se incluirá ninguna información que haga posible la identificación de los participantes. Los registros serán guardados en un lugar seguro y solamente los miembros del grupo investigativo tendrán acceso a la información. En un momento determinado los registros pueden ser revisados mientras se conduce una auditoría por personal autorizado de la Universidad o sus agentes, todos ellos serán regidos por las condiciones de confidencialidad arriba descritas.

\section{COMPENSACIÓN Y COSTOS}

Usted no recibirá pago por su participación ni tendrá costo alguno.

\section{DERECHO A NEGARSE O RETIRARSE}

Su participación en este estudio es totalmente voluntaria. Usted es libre de participar en el estudio o retirar su consentimiento en cualquier momento cuando lo estime. Esta decisión no afectará su elegibilidad para ningún beneficio. El investigador se reserva el derecho de retirarlo del estudio investigativo en cualquier momento y sin su consentimiento según lo estime conveniente.

\section{INFORMACIÓN DEL INVESTIGADOR}

En caso de tener alguna pregunta sobre el propósito, los procedimientos o cualquier otro aspecto de este estudio investigativo, puede comunicarse con Didiana De la Osa por teléfono al 3058789818 o por correo eléctronico a: didiana.delaosa@yahoo.com

\section{INFORMACIÓN DE IRB}

Si desea hablar con alguien sobre sus derechos al participar en este estudio o sobre la ética de este estudio puede comunicarse con la Oficina de Integridad Investigativa de FIU por teléfono al 3053482494 o por correo eléctronico a: ori@,fiu.edu. 


\section{ACUERDO DEL PARTICIPANTE}

He leído y entendido toda la información brindada en este consentimiento y estoy de acuerdo en participar en este estudio investigativo. He tenido la oportunidad de hacer preguntas sobre el estudio y he recibido respuestas. Entiendo que tengo derecho a obtener una copia de esta forma después de firmarla.

Firma del participante

Nombre del participante

Firma de la persona que obtiene el Consentimiento
Fecha

Fecha 
Appendix 3 - Mini Mental Status Exam 


\section{Mini-Mental Status Exam \\ (Mini-examen de status mental)}

I would like to check your memory and concentration.

(Con su permiso, Voy a examinar su memoria y su concentracion)

\section{Orientation}

\section{SCORE}

( ) What is the: (day of the week) (month) (date) (year) (season)? 5 points Cual es: (el dia de la semana) (mes) (fecha) (atio) (epoca del atio)?

( ) Where are we: (hospital) (floor) (town) (county) (state)? 5 points Donde estamos? (hospital) (piso) (pueblo) (condado) (estado)

( ) Repeat the 3 words house, chair, table, Remember these 3 words. 3points Repita estas palabras: CASA, SILLA, MESA, Acuerdese de estas 3 palabras ( 1 point/correct response, only 1 attempt)

\section{Attention and Calculation}

( ) Serial 7: Subtract 7 from 100.Repeat for a total of $5(93,86,79,72,65)$. 5points (1 point for each correct answer on the first attempt) Por favor reste 7 de 100 y siga restando 7 hasta que yo le diga Answer: noventa y tres, ochenta y seis, setenta y nueve, setenta y dos, sesenta y cinco 9386797265

\section{OR}

( ) Spell HOME backwards. (Score 1 point for each letter in the correct place,

$$
\mathrm{D} / \mathrm{C} \text { after first failure) }
$$

Deletree HOGAR alrevez o sea de atras para adelante Answer: R A G $0 \mathrm{H}$ 


\section{Recall}

( ) Repeat the 3 words ( 1 point/correct response, only 1 try),

3 points

Por favor repita las 3 palabras que le dije que se acordara

\section{Language}

( ) Name a pencil (lapiz) and a watch (reloj).

2 points

Como se llama esto? Answer: lapiz y reloj

( ) Repeat the following: "No ifs, ands or buts."

Repita lo siguiente: "Ni porque ni porcuanto" 1 point

( ) 3 stage command: Take this paper with your right hand, fold it in 3 points

half and give it back to me

Tome este papel con su mano derecha, doblelo por la mitad y regreseme el papel

\section{Read and obey the following:}

\section{Lea y obedezca lo siguiente:}

( ) Close your eyes (Cierre sus ojos) 1 point

( ) Write a sentence (Escriba cualquier frase u oracion). 1 point

( ) Copy this drawing (Copie este dibujo) 1 point

\section{Total Score}

\section{DERIVING THE TOTAL SCORE}

Add the number of correct responses. The maximum is 30 .

\section{Total Score}

23-30 $=$ Normal $/ 19-23=$ Borderline $/<19=$ Impaired 


\section{CLOSE YOUR EYES}

(CIERRE SUS OJOS)

WRITE A SENTENCE

(ESCRIBA CUALQUIER FRASE U ORACIÓN)

COPY THIS DRAWING

(COPIE ESTE DIBUJO)

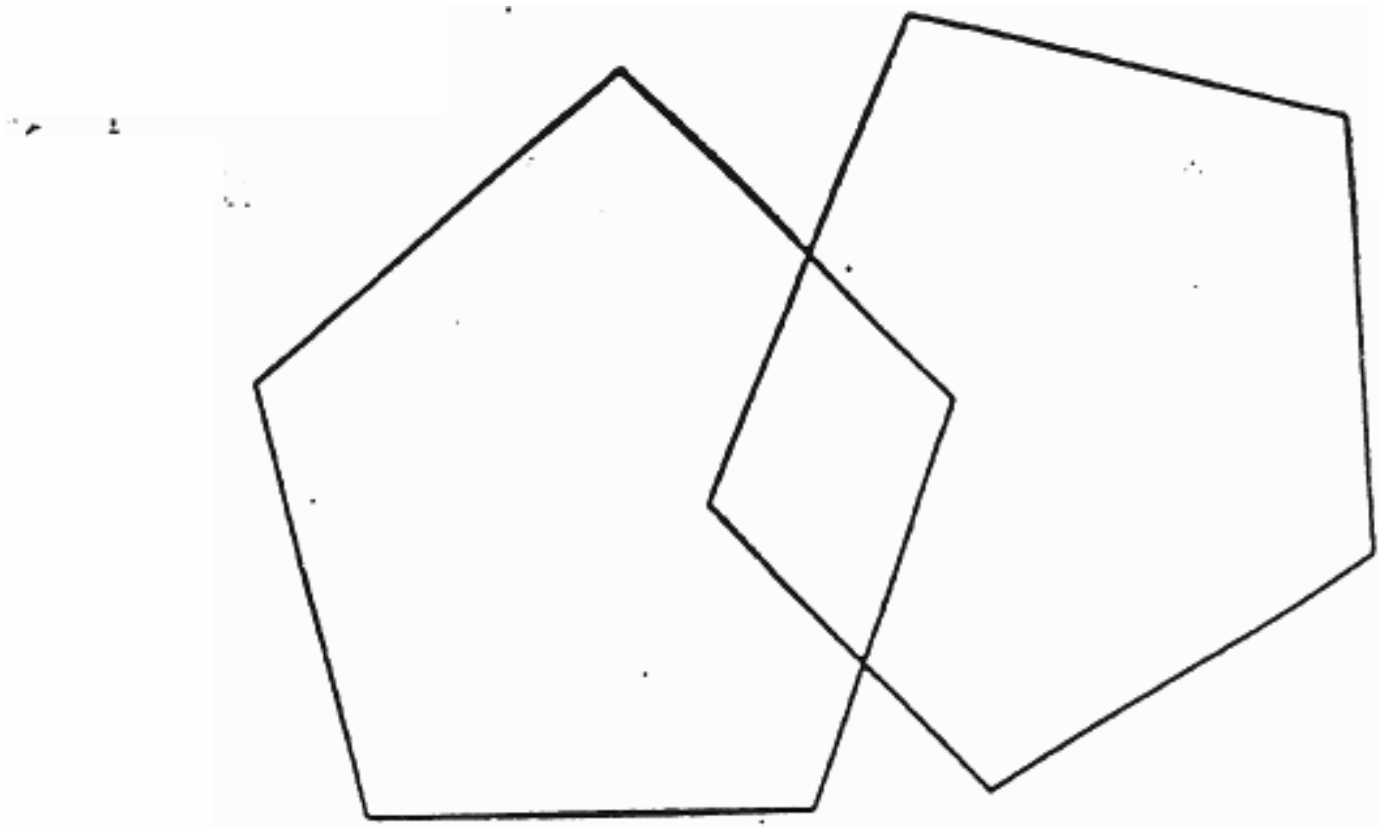


Appendix 4 - General Information Survey 


\section{General Information Survey}

Date:

Interviewer:

Language preferred?

ENGLISH

SPANISH

\section{DEMOGRAPHIC INFORMATION}

1. How old are you?

2. Where were you born?

(town, state, country)

3. Are you? :

MALE

FEMALE

4. What is your ethnic background (check one)?

$\ldots$ African American
Asian
Hispanic
West Indian
White Caucasian
Other

5. What is your religious affiliation (Check one)?

${ }_{-}^{\text {Christian }}$
Catholic
Protestant $_{\text {Jewish }}$ Orthodox




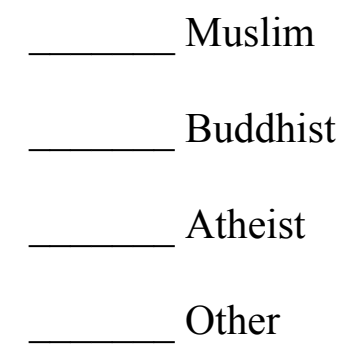

6. What is your current marital status (check one)?

Married
Divorced
Separated
Widowed
Never Married

7. If married, how long have you been married?

8. Do you have any children?

YES NO

9. If so, how many?

10. How many years of school have you completed (check the highest grade completed)?

Graduate or professional degree
College graduate
Partial college
__ High school graduate
Completed grade school
you are married, how many years of school has your SPOUSE completed (check
ghest grade completed)?
Graduate or professional degree
College graduate


Partial college

High school graduate

Completed grade school

12. What is your current employment status (check one)?

$\ldots$ Employed full-time
Employed part-time
Student full-time
Student part-time
Housewife
Unemployed
Volunteer
Retired

13. What is/was your current/previous occupation (be very specific)?

14. If you are/were married, what is/was your SPOUSE'S current/previous occupation (be very specific)?

\section{Code SES:}

\section{HEALTH INFORMATION}

15. In general, would you say your health is (check one)?

Excellent

Good

Fair 
16. Would you say your health is better, about the same, or not as good as others your age (Circle one)?

Better

About the same

Not as good

17. Please indicate how frequently you experience any of the following symptoms, using the scale below:

$\begin{array}{lll}1 & 2 & 3 \\ \text { Never } & \text { Less than } & \text { Every month } \\ \begin{array}{c}\text { or almost } \\ \text { never }\end{array} & \begin{array}{l}\text { 3-4 times } \\ \text { per year }\end{array} & \text { or so } \\ \end{array}$

$\begin{array}{cc}4 & 5 \\ \text { Every week } & \text { More than } \\ \text { or so } & \text { once every } \\ & \text { week }\end{array}$

Eyes water

Itching/painful eyes

Ringing in ears

Temporary deafness/hard of hearing

Lump in throat

Choking Sensations

Sneezing spells

Running nose

Congested nose

Asthma or wheezing

Coughing

Out of breath

Swollen ankles

Chest pains

Racing heart

Cold hands (even in hot temps)

Leg cramps

Insomnia

Toothaches

Upset Stomach

Indigestion

Heartburn

Severe pain/cramps in stomach

Diarrhea

Constipation

Hemorrhoids

Swollen Joints

Stiff muscles

Back Pains

Sensitive or tender skin

Face flushes

Severe itching

Skin breaks out in rash

Acne or pimples on face

Acne or pimples other than face Boils

Sweating (even in cold temps)

Strong reactions to insect bites

Headaches

Sensations of pressure in head

Hot flashes

Chills

Dizziness

Feel faint

Numbness or tingling (anywhere)

Twitching of eyelid

Twitching other than eyelid

Hands tremble or shake

Stiff joints

Sore muscles

Sore throat

Nausea 
18. Do you currently have health problems that worry or concern you? If yes, please describe:

\section{CARE RECIPIENT DISEASE BACKGROUND}

19. What illness has the care recipient been diagnosed with?

20. When was the illness diagnosed?

21. Who diagnosed the care recipient's illness (General Practitioner, Specialist)?

22. How severe do you think the care recipient's disease is (Check one)?

$\ldots$ Not very severe
Mildly severe
M_ Moderately severe
Quite severe
Very severe

23. Is the care recipient currently taking medication?

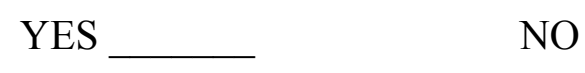

24. If yes, what medication(s) do they take? 
25. How effective are the medications in relieving their symptoms (check one)?

Very effective
Quite effective
Moderately effective
Mildly effective
Not very effective

26. Does the care recipient have any problems with their memory? YES NO

27. If the care recipient does have problems with their memory would you say those problems are (check one)?

Mild

Moderate

Severe 
Appendix 5 - General Information Survey in Spanish 
Fecha:

Nombre de la persona que conduce la entrevista:

Idioma preferido? Inglés ___ Español

\section{INFORMACION DEMOGRAFICA}

1. Que edad tiene?

2. Dónde nació? (Especifique pueblo o ciudad, estado o provincia y país)

3. Cuál es su sexo? Masculino Femenino

4. Indique su ascendencia étnica, (por favor marque solo una de las siguientes opciones):

\begin{tabular}{ll}
\hline Afro-americano \\
Asiático \\
Hispano \\
Indio \\
Blanco Caucásico \\
Otro
\end{tabular}

5. Que religión profesa? (Por favor indique una) Cristianismo

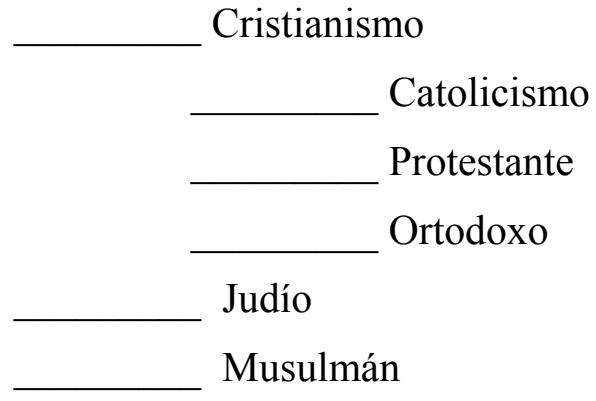




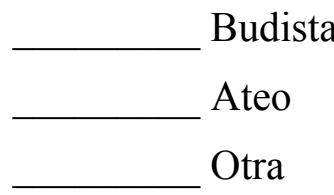

6. Cuál es su estado civil? (Por favor marque una) :

Casado
Divorciado
Separado
Viudo
Soltero (nunca se ha casado)

7. Si es casado, por cuántos años?

8. Tiene hijos? $\mathrm{Si}$

9. Cuántos hijos tiene?

10. Cuál es el último grado escolar terminado? (Por favor marque el mas alto grado terminado)

Graduado o título profesional (Maestría o Doctorado)
Graduado de colegio (Técnico o especialista)
Universidad o Colegio especializado parcial
Bachillerato o Pre-Universitario
Escuela Secundaria o Primaria

11. Si es casado, cuál es el último grado escolar terminado de su ESPOSA(O)? (Por favor marque el mas alto grado terminado)

Graduado o título profesional (Maestría o Doctorado)
Graduado de colegio (Técnico o especialista)
Universidad o Colegio especializado parcial
Bachillerato o Pre-Universitario
Escuela Secundaria o Primaria


12. Cuál es su estado laboral? (Por favor marque uno)

$\begin{array}{ll} & \text { Tiempo Completo } \\ & \text { Tiempo Parcial } \\ & \text { Estudiante tiempo Completo } \\ \text { Estudiante Tiempo Parcial } \\ & \text { Ama de Casa } \\ & \text { Desempleado } \\ & \text { Voluntario } \\ & \text { Retirado }\end{array}$

13. Cuál es su ocupación o empleo actual o pasado si es retirado o desempleado? (Por favor especifique.)

14. Cuál es la ocupación o empleo, actual o pasado si retirada(o) o desempleada(o) de su ESPOSA(O) ? Por favor especifique.

Código SES:

\section{INFORMACION DE SALUD}

15. Como considera usted su salud? (Marque una opción)

Excelente
Buena
Regular
Mala

16. Piensa usted que su salud es mejor, igual o peor que otras personas de su edad? Marque una opción por favor.

Mejor
Igual
Peor


17. Por favor indique cuán frecuentemente experimenta usted los siguientes síntomas, usando la escala ofrecida a continuación:

1

Nunca 0

casi nunca$$
2
$$

Menos de

3 ó 4 veces al año

Ojos Llorosos

Picazón o dolor en los ojos

Sonido o ruido en los oídos

Sordera temporal o dificultad para oír

Masa o sensación de nudo en la garganta

Atoros o ahogamientos

Estornudos

Secreción nasal continuada

(Agua por la nariz)

Congestión nasal

Asma o silbido en el pecho

Tos

Falta de aire

Tobillos inflamados

Dolor de pecho

Rapidez en los sonidos del corazón

Manos frías (aunque la temperatura sea alta)

Calambres en las piernas

Insomnia

Dolores de muela o de dientes

Molestias estomacales

Acidez

Dolores fuertes de estómago

Diarrea

Extreñimiento

Hemorroides

Articulaciones inflamadas

Espasmos musculares

Dolor de espalda

Piel sensitiva

Calores y enrojecimiento en la cara

Picazones

\section{3}

4

5

Todos los Todas las Más de una

meses semanas o casi vez a la semana todas las semanas
Urticarias o erupciones de la piel

Acné, granitos o comedones en la cara

Acné, granitos o comedones en otro lugar que no sea la cara

Furúnculo

Sudores aunque la temperatura no sea muy caliente

Reacciones fuertes a las picaduras de insecto

Dolores de cabeza

Sensación de presión en la cabeza

Calores repentinos

Escalofríos

Mareos

Desmayos

Entumecimientos

Movimientos involuntarios de los párpados

Movimientos involuntarios en otra parte del cuerpo

Temblores en las manos

Articulaciones rígidas

Dolores musculares

Dolor de garganta

Nausea 
CORRELATES AMONG COPING SKILLS AND LIFE SATISFACTION

III. ENFERMEDADES DE LA PERSONA QUE RECIBE LOS CUIDADOS

18. Qué enfermedades le han sido diagnosticadas a la persona que cuida?

19. Cuándo fue hecho el diágnostico?

20. Quién hizo el diágnostico? (Especifique especialista, médico general)

21. Indique según su criterio, la severidad de la(s) enfermedades de la peresona que usted cuida?

No es severa
Poco severa
Severidad moderada
Severa
Muy severa

22. Está la persona que cuida tomando medicamentos? Si

No

23. Liste los medicamentos que toma

24. Cuán efectivos son los medicamentos en aliviar los síntomas? Marque una opción Muy efectivo

Algo efectivo
Moderadamente efectivo
Poco efectivo
No muy efectivo

25. Tiene la persona que usted cuida algún problema con la memoria?

$\mathrm{Si}$ No 
25. Si la respuesta es afirmativa a la pregunta anterior, por favor especifique la magnitud de los problemas de memoria

$\begin{array}{ll} & \text { Ligeros } \\ & \text { Moderados } \\ & \text { Severos }\end{array}$


Appendix 6 - Familism Scale 


\section{Familism Scale}

Below is a list of issues concerning the family in general, not your own. Please read all statements very carefully and respond to all of them on the basis of your own true beliefs without consulting any other persons. Do this by reading each statement and then writing, in the space provided at its left, only one of the following numbers: $0,1,2,3,4$. The meaning of each of these figures is:

0: Strongly disagree 1: Disagree 2: Undecided 3: Agree 4: Strongly agree (For research purposes, you must consider all statements as they are, without modifying any of them in any way.)

1. ___ One should make great sacrifices in order to guarantee a good education for his/her children.

2. One should help economically with the support of younger brothers and sisters.

3. When someone has problems s/he can count on help from his/her relatives.

4. When one has problems, one can count on the help of relatives.

5. ___ One can count on help from his/her relatives to solve most problems.

6. ___ Much of what a son or daughter does should be done to please the parents.

7. __ One should be embarrassed about the bad things done by his/her brothers or sisters.

8. _ Children should live in their parents' house until they get married.

9. One of the most important goals in life is to have children. 
Appendix 7 - Familism Scale in Spanish 


\section{Escale de Familismo}

A continuación se presenta una lista de declaraciones en cuanto a las familias en general, no sobre su propia familia. Lea todas las instrucciones cuidadosamente y responda a todas las declaraciones basado en sus propias creencias verdaderas sin consultar a las demás personas. Haga esto mediante la lectura de cada declaración y, a continuación, escriba, en el espacio proporcionado a su izquierda, sólo uno de los siguientes números:

$0,1,2,3,4$. El significado de cada una de estas cifras es:

$$
\text { 0: Totalmente en desacuerdo 1: En desacuerdo 2: Indecisos }
$$

3: De acuerdo 4: Totalmente de acuerdo

(Con fines de investigación, debe tener en cuenta todas las declaraciones como son, sin modificar las de ninguna manera.)

1. Uno debería hacer grandes sacrificios con el objetivo de garantizar una buena educaci n para sus hijos

2. Uno debería ayudar econ micamente en el sostenimiento de sus hermanos y hermanas pequeños

3. Cuando alguien tiene problemas, puede contar con la ayuda de sus familiares

4. ___ Cuando uno mismo tiene problemas, puede contar con la ayuda de sus familiars

5. ___ Uno puede contar con la ayuda de sus familiares para solucionar la mayoría de los problemas

6. L__ La mayoría de lo que hace un hijo o una hija debería hacerse para agradar a sus padres 
7. Uno debería avergonzarse por las cosas malas hechas por sus hermanos o hermanas

8. __ Deben vivir los hijos en casa de sus padres hasta que se casen.

9. __ Uno de los objetivos más importantes en la vida es tener hijos 
Appendix 8 - Filial Piety Scale in English 


\section{Filial Piety Scale}

The following items are concerned with filial piety, We would like to know what your opinions are on these items. There are no "right" or "wrong" answers. So please respond according to your own personal opinions.

For each item, select only one of the following six alternatives:

$1=$ Strongly agree

$2=$ Disagree

$3=$ Mildly disagree

$4=$ Mildly agree

5= Agree

$6=$ Strongly agree

Please do not skip any item.

1. ___ Sons and daughters may protest against being unreasonably scolded by their parents. (N)

2. There is no place under the sun for both oneself and the enemy of one's father.

3. If If there is a reason for doing so, one may rely on an old people's home to provide for one's aged parents. (N)

4. ___ Any sacrifice is worthwhile for the sake of filial piety.

5. ___ Sons and daughters should not go to faraway while their parents are still living.

6. __ In choosing a spouse, sons and need not follow "the parents' command". (N) 
7. ___ The main reason for sons and daughters not to do dangerous things is to avoid getting their parents worried.

8. ___ Parents should not interfere with their children's freedom to choose a vocation $(\mathrm{N})$

9. The great debt that you have to repay your parents is as endless as the sky. 10. __ "Rearing sons to provide for oneself in one's old age" should no longer be the main purpose of raising children. $(\mathrm{N})$

11. No matter how their parents conduct themselves, sons and daughters must respect them.

12. After the father has passed away, sons and daughters must conduct themselves according to the principles and attitudes he followed while he was still living.

13. If there is a quarrel between one's wife and one's mother, the husband should advise his wife to listen to his mother.

14. After their parents have passed away, sons and daughters do not necessarily have to finish the business left unfinished by their parents. $(\mathrm{N})$

15. __ "Spreading one's fame to glorify one's parents" should not be the most important reason for getting ahead. (N)

16. To worship their ancestors regularly on the proper occasions is the primary duty of sons and daughters.

17. To continue the family line is not the primary purpose of marriage. (N) 18. Sons and daughters do not necessarily have to seek parental advice and may make their own decisions. (N) 
19. Sons and daughters do not necessarily have to respect the people respected and loved by their parents. $(\mathrm{N})$

20. __ After children have grown up, all the money they earn through their own labor belongs to themselves, even though their parents are still living. $(\mathrm{N})$

21. _ "There is no crime worse than being unfilial".

22. ___ As a son or daughter, one must obey one's parents no matter what. 
Appendix 9 - Filial Piety Scale in Spanish 


\section{Piedad Filial Escala (FP)}

Los siguientes incisos están relacionados con la piedad filial. Quisiéramos saber su opinión acerca de cada uno de ellos. No existe una respuesta correcta o incorrecta, solo responda lo que usted cree usando las opciones que se ofrecen a continuación:

$$
\begin{aligned}
& 1=\text { Totalmente en desacuerdo } \\
& 2=\text { Desacuerdo } \\
& 3=\text { Desacuerdo parcial } \\
& 4=\text { Acuerdo parcial } \\
& 5=\text { Estoy de acuerdo } \\
& 6=\text { Totalmente de acuerdo }
\end{aligned}
$$

Por favor exponga su opinión en todos y cada uno.

1. __ Los hijos tienen derecho a protestar ante una reprimenda exagerada de sus padres.

2. __ No existe lugar en el mundo donde puedan co-existir un hijo(a) y el enemigo de su padre.

3. _ Si existe una razón válida para hacerlo, está bien ingresar a padre o madre en un asilo de ancianos.

4. _ Cualquier sacrificio vale la pena po mantener la piedad filial

5. __ Los hijos no deben alejarse mucho de sus padres mientras estos vivan.

6. _ Cuando los hijos escogen esposa(o) no necesariamente deben seguigr el consejo de los padres. 
7. __ La razón principal por la que los hijos no hacen cosas que impliquen peligro es para no preocupar a sus padres.

8. _ _ L L L _ _ padres no deben interferir con la libertad de sus hijos para decidir su vocación.

9. __ La gran deuda que los hijos tienen con sus padres no tiene límites.

10. __ Nunca los padres criarán hijos con el único propósito de tener quien los cuide en la vejez.

11. __ No importa como se comporten los padres, los hijos siempre los respetarán.

12. __ Después que los padres se mueran, los hijos deben conducir su vida de acuerdo a los principios y actitudes que sus padres observaron mientras en vida.

13. __ Si existen diferencias entre una esposa(o) y una madre, siempre el esposo(a) hará hincapié en escuchar y obedecer a la madre.

14. __ Después del fallecimiento de los padres, los hijos no son responsable de terminar u ocuparse de los asuntos que ellos dejaron pendientes.

15. ___ El afán de glorificar a un padre o madre no es la razón más importante para batallar por salir adelante en la vida.

16. __ La principal responsabilidad de los hijos es venerar regularmente sus antecesores en cada ocasión que tengan.

17. __ El principal propósito del matrimonio no es perpetuar un apellido 18. __ Los hijos deben tomar decisiones propias y no necesariamente tienen que pedir consejo a sus padres. 
19. _ L L L L hijos no tienen que respetar y querer las mismas personas que sus padres querían y respetaban.

20. _ Después de llegar a la edad adulta, los hijos pueden gastar o decidir que hacer con el dinero ganado por ellos mismos producto de su trabajo aunque sus padres estén vivos.

21. __ No hay peor falta que no ser filial

22. __ Los hijos siempre deben obedecer a los padres sin importar nada más. 
Appendix 10 - The COPE Scale 


\section{The COPE}

We are interested in how people respond when they confront difficult or stressful events in their lives. There are lots of ways to try to deal with stress. This questionnaire asks you to indicate what you generally do and feel, when you experience stressful events. Obviously, different events bring out somewhat different responses, but think about what you usually do when you are under a lot of stress.

Then respond to each of the following items by blackening one number on your answer sheet for each, using the response choices listed just below. Please try to respond to each item separately in your mind from each other item. Choose your answers thoughtfully, and make your answers as true FOR YOU as you can. Please answer every item. There are no "right" or "wrong" answers, so choose the most accurate answer for YOU--not what you think "most people" would say or do. Indicate what YOU usually do when YOU experience a stressful event.

$1=\mathrm{I}$ usually don't do this at all

$2=\mathrm{I}$ usually do this a little bit

$3=\mathrm{I}$ usually do this a medium amount

$4=$ I usually do this a lot

1. I try to grow as a person as a result of the experience.

2. I turn to work or other substitute activities to take my mind off things.

3. I get upset and let my emotions out.

4. I try to get advice from someone about what to do. 
5. I concentrate my efforts on doing something about it.

6. I say to myself "this isn't real."

7. I put my trust in God.

8. I laugh about the situation.

9. I admit to myself that I can't deal with it, and quit trying.

10. I restrain myself from doing anything too quickly.

11. I discuss my feelings with someone.

12. I use alcohol or drugs to make myself feel better.

13. I get used to the idea that it happened.

14. I talk to someone to find out more about the situation.

15. I keep myself from getting distracted by other thoughts or activities.

16. I daydream about things other than this.

17. I get upset, and am really aware of it.

18. I seek God's help.

19. I make a plan of action.

20. I make jokes about it.

21. I accept that this has happened and that it can't be changed.

22. I hold off doing anything about it until the situation permits.

23. I try to get emotional support from friends or relatives.

24. I just give up trying to reach my goal.

25. I take additional action to try to get rid of the problem.

26. I try to lose myself for a while by drinking alcohol or taking drugs. 
27. I refuse to believe that it has happened.

28. I let my feelings out.

29. I try to see it in a different light, to make it seem more positive.

30. I talk to someone who could do something concrete about the problem.

31. I sleep more than usual.

32. I try to come up with a strategy about what to do.

33. I focus on dealing with this problem, and if necessary let other things slide a little.

34. I get sympathy and understanding from someone.

35. I drink alcohol or take drugs, in order to think about it less.

36. I kid around about it.

37. I give up the attempt to get what I want.

38. I look for something good in what is happening.

39. I think about how I might best handle the problem.

40. I pretend that it hasn't really happened.

41. I make sure not to make matters worse by acting too soon.

42. I try hard to prevent other things from interfering with my efforts at dealing with this.

43. I go to movies or watch TV, to think about it less.

44. I accept the reality of the fact that it happened.

45. I ask people who have had similar experiences what they did.

46. I feel a lot of emotional distress and I find myself expressing those feelings a lot.

47. I take direct action to get around the problem. 
48. I try to find comfort in my religion.

49. I force myself to wait for the right time to do something.

50. I make fun of the situation.

51. I reduce the amount of effort I'm putting into solving the problem.

52. I talk to someone about how I feel.

53. I use alcohol or drugs to help me get through it.

54. I learn to live with it.

55. I put aside other activities in order to concentrate on this.

56. I think hard about what steps to take.

57. I act as though it hasn't even happened.

58. I do what has to be done, one step at a time.

59. I learn something from the experience.

60. I pray more than usual. 
Appendix 11 - The COPE Scale in Spanish 


\section{COPE en Español}

Estamos interesados en la forma en que las personas responden cuando tienen que hacer frente a acontecimientos difíciles o estresantes en sus vidas. Hay muchas formas de intentar manejar el estrés, Este cuestionario le pide que indique lo que generalmente hace y siente cuando experimenta acontecimientos estresantes. Obviamente, sucesos diferentes provocan respuestas algo diferentes, pero piense acerca de lo que hace habitualmente cuando está bajo un estrés intenso. Entonces responda a cada uno de los siguientes ítems marcando el número que corresponda, utilizando las opciones de respuesta que se presentan abajo. Por favor, intente responder a cada ítem de forma separada a los demás. Elija sus respuestas cuidadosamente, y responda de la forma más sincera que le sea posible. Por favor responda todos los ítems. No hay respuestas correctas o incorrectas, de modo que elija la respuestas que más se le ajuste a usted no la que usted piense que la mayoría de la gente diría o haría. Indique lo que USTED habitualmente hace cuando experimenta un acontecimiento estresante.

$1=$ No suelo hacer esto en absoluto

$2=$ Suelo hacer esto un poco

$3=$ Suelo hacer esto moderadamente

$4=$ Suelo hacer esto mucho.

1. Intento desarrollarme como persona como resultado de la experiencia.

2. Me concentro en el trabajo u otras actividades sustitutivas para alejar el tema de mi mente. 
3. Me altero y dejo aflorar mis emociones.

4. Intento conseguir consejo de alguien sobre qué hacer.

5. Concentro mis esfuerzos en hacer algo acerca de la situación.

6. Me digo a mí mismo: "Esto no es real"

7. Confío en Dios.

8. Me río acerca de la situación.

9. Admito que no puedo con ello y dejo de intentarlo.

10. Me disuado a mi mismo de hacer algo con demasiada rapidez.

11. Hablo de mis sentimientos con alguien.

12. Consumo alcohol o drogas para sentirme mejor

13. Me acostumbro a la idea de lo que sucedió.

14. Hablo con alguien para saber más acerca de la situación.

15. Evito distraerme con otros pensamientos o actividades.

16. Sueño despierto con otras cosas diferentes.

17. Me altero y soy realmente consciente de la situación.

18. Pido la ayuda de Dios.

19. Hago un plan de acción.

20. Hago bromas sobre la situación.

21.Acepto que ha sucedido y que no puede cambiarse.

22. Demoro hacer algo sobre el tema hasta que la situación lo permita.

23. Intento conseguir apoyo emocional de amigos o familiares.

24. Simplemente abandono en el intento de lograr mi objetivo.

25. Tomo medidas adicionales para intentar librarme del problema. 
26. Intento evadirme un rato bebiendo alcohol o tomando drogas.

27. Me niego a creer que haya sucedido.

28. Dejo aflorar mis sentimientos.

29. Intento verlo de una forma diferente, para que parezca más positivo.

30. Hablo con alguien que pudiera hacer algo concreto acerca del problema.

31. Duermo más de lo habitual.

32.Intento encontrar una estrategia acerca de qué hacer.

33. Me concentro en el manejo del problema y si es necesario aparto otros temas un poco.

34. Consigo la compasión y comprensión de alguien.

35. Bebo alcohol o tomo drogas para pensar menos en ello.

36. Bromeo sobre ello

37. Renuncio a intentar lograr lo que quiero.

38. Busco algo bueno en lo que está sucediendo.

39. Pienso acerca de cómo podría manejar mejor el problema.

40. Actúo como si realmente no hubiera sucedido

41. Me aseguro de no empeorar las cosas por actuar demasiado pronto.

42. Intento evitar que otras cosas interfieran con mis esfuerzos de manejar la situación.

43. Voy al cine o veo la televisión para pensar menos en ello.

44. Acepto la realidad del hecho que ha sucedido.

45. Pregunto a personas que han tenido experiencias similares qué hicieron.

46. Siento un gran malestar emocional y me encuentro expresando estos sentimientos un montón. 
47. Llevo a cabo una acción directa en torno al problema.

48 Intento encontrar consuelo en la religión.

49. Me obligo a mi mismo a esperar el momento oportuno para hacer algo.

50. Hago bromas de la situación.

51. Reduzco la cantidad de esfuerzo que dedico a resolver el problema.

52. Hablo con alguien acerca de cómo me siento

53. Utilizo alcohol o drogas para ayudarme a superarlo.

54. Aprendo a vivir con ello.

55. Dejo de lado otras actividades para concentrarme en el problema

56. Pienso profundamente acerca de qué pasos tomar.

57. Actúo como si nunca hubiera ocurrido.

58. Hago lo que hay que hacer, paso a paso.

59. Aprendo algo de la experiencia.

60. Rezo más de lo habitual. 
Appendix 12 - The Burden Interview 


\section{ZARIT BURDEN INTERVIEW}

Instructions: The following is a list of statements, which reflect how people sometimes feel when taking care of another person. After each statement, indicate how often you feel that way, never, rarely, sometimes, quite frequently, or nearly always. There are no right or wrong answers

1) Do you feel that your relative asks for more help than $\mathrm{s} / \mathrm{he}$ needs?

Never Rarely Sometimes Quite Frequently Nearly Always
0()
1()
2()
3()
4()

2) Do you feel that because of the time you spend with your relative, you don't have enough time for myself?

$\begin{array}{lllll}\text { Never } & \text { Rarely } & \text { Sometimes } & \text { Quite Frequently } & \text { Nearly Always } \\ 0() & 1() & 2() & 3() & 4()\end{array}$

3) Do you feel stressed between caring for your relative and trying to meet other responsibilities for your family or work?

Never Rarely Sometimes Quite Frequently Nearly Always
0()
1()
2()
3()
4()

4) Do you feel embarrassed over your relative's behavior?

$\begin{array}{lllll}\text { Never } & \text { Rarely } & \text { Sometimes } & \text { Quite Frequently } & \text { Nearly Always } \\ 0() & 1() & 2() & 3() & 4()\end{array}$

5) Do you feel angry when you are around your relative?

Never Rarely Sometimes Quite Frequently Nearly Always
0()
1()
2()
3()
4() 
6) Do you feel that your relative currently affects your relationship with other family members or friends in a negative way?

Never Rarely Sometimes Quite Frequently Nearly Always
0()
1()
2()
3()
4()

7) Are you afraid what the future holds for you relative?

$\begin{array}{lllll}\text { Never } & \text { Rarely } & \text { Sometimes } & \text { Quite Frequently } & \text { Nearly Always } \\ 0() & 1() & 2() & 3() & 4()\end{array}$

8) Do you feel your relative is dependent upon you?

Never Rarely Sometimes Quite Frequently Nearly Always
0()
1()
2()
3()
4()

9) Do you feel strained when you are around your relative?

$\begin{array}{lllll}\text { Never } & \text { Rarely } & \text { Sometimes } & \text { Quite Frequently } & \text { Nearly Always } \\ 0() & 1() & 2() & 3() & 4()\end{array}$

10) Do you feel your health has suffered because of you involvement with your relative?

$\begin{array}{lllll}\text { Never } & \text { Rarely } & \text { Sometimes } & \text { Quite Frequently } & \text { Nearly Always } \\ 0() & 1() & 2() & 3() & 4()\end{array}$

11) Do you feel that you don't have as much privacy as you would like because of your relative?

$\begin{array}{lllll}\text { Never } & \text { Rarely } & \text { Sometimes } & \text { Quite Frequently } & \text { Nearly Always } \\ 0() & 1() & 2() & 3() & 4()\end{array}$


12) Do you feel that your social life has suffered because you are caring for your relative?

$\begin{array}{lllll}\text { Never } & \text { Rarely } & \text { Sometimes } & \text { Quite Frequently } & \text { Nearly Always } \\ 0() & 1() & 2() & 3() & 4()\end{array}$

13) Do you feel uncomfortable about having friends over because of you relative? Never Rarely Sometimes Quite Frequently Nearly Always
0()
1()
2()
3()
4()

14) Do you feel that your relative seems to expect you to take care of him/her as if you were the only one he/she could depend on?

$\begin{array}{lllll}\text { Never } & \text { Rarely } & \text { Sometimes } & \text { Quite Frequently } & \text { Nearly Always } \\ 0() & 1() & 2() & 3() & 4()\end{array}$

15) Do you feel that you don' $t$ have enough money to care for your relative, in addition to the rest of your expenses?

Never Rarely Sometimes Quite Frequently Nearly Always
0()
1()
2()
3()
4()

16) Do you feel that you will be unable to take care of your relative much longer? Never Rarely Sometimes Quite Frequently Nearly Always
0()
1()
2()
3()
4()

17) Do you feel you have lost control of your life since your relative's illness?

Never Rarely Sometimes Quite Frequently Nearly Always
0()
1()
2()
3()
4() 
18) Do you wish you could just leave the care of your relative to someone else? Never Rarely Sometimes Quite Frequently Nearly Always
0()
1()
2()
3()
4()

19) Do you feel uncertain about what to do about your relative?

Never Rarely Sometimes Quite Frequently Nearly Always
0()
1()
2()
3()
4()

20) Do you feel you should be doing more for your relative?

Never Rarely Sometimes Quite Frequently Nearly Always
0()
1()
2( )
3()
4()

21) Do you feel you could do a better job in caring for you relative?

Never Rarely Sometimes Quite Frequently Nearly Always
0()
1()
2()
3()
4()

22) Overall, how burdened do you feel in caring for your relative?

Never Rarely Sometimes Quite Frequently Nearly Always
0()
1()
2()
3()
4() 
Appendix 13 - The Burden Interview in Spanish 


\section{CUESTIONARIO DE SOBRECARGA DEL CUIDADOR}

(Escala de Zarit)

INSTRUCCIONES: A continuación se presentan una lista de frases que reflejan como se sienten algunas personas cuando cuidan a otra persona. Después de leer cada frase, indique con qué frecuencia se siente usted de esa manera, escogiendo entre Nunca, Casi Nunca, A Veces, Frecuentemente y Casi Siempre. No existen respuestas correctas o incorrectas.

CON QUE FRECUENCIA (rodee con un círculo la opción elegida)

1) ¿Con que frecuencia siente usted que su familiar/paciente solicita más ayuda de la que realmente necesita?

$\begin{array}{llllr}\text { Nunca } & \text { Casi Nunca } & \text { A Veces } & \text { Frecuentemente } & \text { Casi Siempre } \\ 1() & 2() & 3() & 4() & 5()\end{array}$

2) ¿Con que frecuencia siente usted que, a causa del tiempo que gasta con su familiar/paciente, ya no tiene tiempo suficiente para usted mismo?

Nunca Casi Nunca A Veces Frecuentemente Casi Siempre
1()
2()
3()
4()
5()

3) ¿Con que frecuencia se siente estresada(o) al tener que cuidar a su familiar/paciente y tener además que atender otras responsabilidades? (Ej: con su familia o en el trabajo)

$\begin{array}{llllr}\text { Nunca } & \text { Casi Nunca } & \text { A Veces } & \text { Frecuentemente } & \text { Casi Siempre } \\ 1() & 2() & 3() & 4() & 5()\end{array}$


4) ¿Con que frecuencia se siente avergonzada(o) por el comportamiento de su familiar/paciente?

Nunca Casi Nunca A Veces Frecuentemente Casi Siempre
1()
2()
3()
4()
5()

5) ¿Con que frecuencia se siente irritada(o) cuando está cerca de su familiar/paciente?

Nunca Casi Nunca A Veces Frecuentemente Casi Siempre
1()
2()
3()
4()
5()

6) ¿Con que frecuencia cree que la situación actual afecta a su relación con amigos u otros miembros de su familia de una forma negativa?

$\begin{array}{llllr}\text { Nunca } & \text { Casi Nunca } & \text { A Veces } & \text { Frecuentemente } & \text { Casi Siempre } \\ 1() & 2() & 3() & 4() & 5()\end{array}$

7) ¿Con que frecuencia siente temor por el futuro que le espera a su familiar/paciente?

$\begin{array}{llllr}\text { Nunca } & \text { Casi Nunca } & \text { A Veces } & \text { Frecuentemente } & \text { Casi Siempre } \\ 1() & 2() & 3() & 4() & 5()\end{array}$

8) ¿Con que frecuencia siente que su familiar/paciente depende de usted?

$\begin{array}{llllr}\text { Nunca } & \text { Casi Nunca } & \text { A Veces } & \text { Frecuentemente } & \text { Casi Siempre } \\ 1() & 2() & 3() & 4() & 5()\end{array}$


9) ¿Con que frecuencia se siente agotada(o) cuando tiene que estar junto a su familiar/paciente?

Nunca Casi Nunca A Veces Frecuentemente Casi Siempre
1 ( )
2 ( )
3()
4 ( )
5 ()

10) ¿Con que frecuencia siente usted que su salud se ha visto afectada por tener que cuidar a su familiar/paciente?

Nunca Casi Nunca A Veces Frecuentemente Casi Siempre
1 ( )
2()
3()
4()
$5($ )

11) ¿Con que frecuencia siente que no tiene la vida privada que desearía a causa de su familiar/paciente?

$\begin{array}{llllr}\text { Nunca } & \text { Casi Nunca } & \text { A Veces } & \text { Frecuentemente } & \text { Casi Siempre } \\ 1() & 2() & 3() & 4() & 5()\end{array}$

12) ¿Con que frecuencia Siente cree que sus relaciones sociales se han visto afectadas por tener que cuidar a su familiar/paciente?

Nunca Casi Nunca A Veces Frecuentemente Casi Siempre

$1\left(\begin{array}{llll}() & 3() & 4() & 5()\end{array}\right.$

13) (SOLAMENTE SI EL ENTREVISTADO VIVE CON EL PACIENTE). ¿Con que frecuencia siente se siente incómoda(o) para invitar amigos a casa, a causa de su familiar/paciente?

$\begin{array}{llllr}\text { Nunca } & \text { Casi Nunca } & \text { A Veces } & \text { Frecuentemente } & \text { Casi Siempre } \\ 1() & 2() & 3() & 4() & 5()\end{array}$


14) ¿Con que frecuencia cree que su familiar/paciente espera que usted le cuide, como si fuera la única persona con la que pudiera contar?

Nunca Casi Nunca A Veces Frecuentemente Casi Siempre
1()
2()
$3($ )
4 ( )
5()

15) ¿Con que frecuencia cree usted que no dispone de dinero suficiente para cuidar de su familiar/paciente, además de sus otros gastos?

$\begin{array}{llllr}\text { Nunca } & \text { Casi Nunca } & \text { A Veces } & \text { Frecuentemente } & \text { Casi Siempre } \\ 1() & 2() & 3() & 4() & 5()\end{array}$

16) ¿Con que frecuencia siente que no va a ser capaz de cuidar de su familiar/paciente durante mucho más tiempo?

$\begin{array}{llllr}\text { Nunca } & \text { Casi Nunca } & \text { A Veces } & \text { Frecuentemente } & \text { Casi Siempre } \\ 1() & 2() & 3() & 4() & 5()\end{array}$

17) ¿Con que frecuencia siente que ha perdido el control sobre su vida desde que la enfermedad de su familiar/paciente se manifestó?

$\begin{array}{llllr}\text { Nunca } & \text { Casi Nunca } & \text { A Veces } & \text { Frecuentemente } & \text { Casi Siempre } \\ 1() & 2() & 3() & 4() & 5()\end{array}$

18) ¿Con que frecuencia desearía poder encargar el cuidado de su familiar/paciente a otra persona?

$\begin{array}{llllr}\text { Nunca } & \text { Casi Nunca } & \text { A Veces } & \text { Frecuentemente } & \text { Casi Siempre } \\ 1() & 2() & 3() & 4() & 5()\end{array}$


19) ¿Con que frecuencia se siente insegura(o) acerca de lo que debe hacer con su familiar/paciente?

$\begin{array}{llllr}\text { Nunca } & \text { Casi Nunca } & \text { A Veces } & \text { Frecuentemente } & \text { Casi Siempre } \\ 1() & 2() & 3() & 4() & 5()\end{array}$

20) ¿Con que frecuencia siente que debería hacer más de lo que hace por su familiar/paciente?

$\begin{array}{llllr}\text { Nunca } & \text { Casi Nunca } & \text { A Veces } & \text { Frecuentemente } & \text { Casi Siempre } \\ 1() & 2() & 3() & 4() & 5()\end{array}$

21) ¿Con que frecuencia cree que podría cuidar a su familiar/paciente mejor de lo que lo hace?

$\begin{array}{llllr}\text { Nunca } & \text { Casi Nunca } & \text { A Veces } & \text { Frecuentemente } & \text { Casi Siempre } \\ 1() & 2() & 3() & 4() & 5()\end{array}$

22) En general, ¿con que frecuencia se siente muy sobrecargada(o) al tener que cuidar de su familiar/paciente?

$\begin{array}{llllr}\text { Nunca } & \text { Casi Nunca } & \text { A Veces } & \text { Frecuentemente } & \text { Casi Siempre } \\ 1() & 2() & 3() & 4() & 5()\end{array}$


Appendix 14 - The Satisfaction with Life Scale 


\section{Satisfaction with Life Scale}

Instructions for administering the scale are: Below are five statements with which you may agree or disagree. Using the 1-7 scale below, indicate your agreement with each item by placing the appropriate number on the line preceding that item. Please be open and honest in your responding.

The 7-point scale is: 1 =strongly disagree, 2 = disagree, 3 = slightly disagree, $4=$ neither agree nor disagree, 5 =slightly agree, $6=$ agree, $7=$ strongly agree.

1. In most ways my life is close to my ideal.

2. The conditions of my life are excellent.

3. I am satisfied with my life.

4. So far I have gotten the important things I want in life.

5. If I could live my life over, I would change almost nothing. 
Appendix 15 - The Satisfaction with Life Scale in Spanish 


\section{Escale sobre la Satisfaccion con La Vida}

Instrucciones para la administración de la escala son: a continuación se presentan cinco declaraciones con las que usted puede estar en acuerdo o en desacuerdo. Utilizando la escala de 1-7 a continuación, indique su acuerdo con cada elemento, colocando el número apropiado en la línea anterior a ese tema. Por favor, sea abierto(a) y honesto(a) en su respuesta.

La escala de 7 puntos: $1=$ totalmente en desacuerdo, $2=$ desacuerdo, $3=$ ligeramente en desacuerdo, 4 = ni de acuerdo ni en desacuerdo, $5=$ ligeramente de acuerdo, $6=$ acuerdo, $7=$ muy de acuerdo.

1. El tipo de vida que llevo se parece al tipo de vida que siempre soñé llevar.

2. Las condiciones de mi vida son excelentes.

3. Estoy satisfecho con mi vida.

4. Hasta ahora he obtenido las cosas importantes que quiero en la vida.

5. Si pudiera vivir mi vida de nuevo, me gustaría que todo volviese a ser igual. 
Appendix 16 - Center for Epidemiological Studies - Depression 
Exhibit 6.3

Note: Iterns $4,8,12$, and 16 have their scores reversed before roralling.

\begin{tabular}{|c|c|c|c|c|}
\hline During the past week: & $\begin{array}{l}\text { Rarely or } \\
\text { none of } \\
\text { the time } \\
\text { (less than } 1 \text { day) }\end{array}$ & $\begin{array}{l}\text { Some or a } \\
\text { lirtle of } \\
\text { the time } \\
\text { (1-2 days) }\end{array}$ & $\begin{array}{l}\text { Occasionally } \\
\text { or a } \\
\text { moderate } \\
\text { amount of the } \\
\text { time ( } 3-4 \text { days) }\end{array}$ & $\begin{array}{l}\text { Most or } \\
\text { all of } \\
\text { the time: } \\
(5-7 \text { days }\end{array}$ \\
\hline $\begin{array}{l}\text { 1. I was bothered by things that usually } \\
\text { don't bother me }\end{array}$ & 0 & 1 & 2 & 3 \\
\hline $\begin{array}{l}\text { 2. I did not feel like eating; my apperite was } \\
\text { poor }\end{array}$ & 0 & 1 & 2 & 3 \\
\hline $\begin{array}{l}\text { 3. I felt that I could not shake off the blues } \\
\text { even with help from my family or friends }\end{array}$ & 0 & 1 & 2 & 3 \\
\hline $\begin{array}{l}\text { 4. I felt that I was just as good as other } \\
\text { people }\end{array}$ & 0 & 1 & 2 & 3 \\
\hline $\begin{array}{l}\text { 5. I had trouble keeping my mind on what I } \\
\text { was doing }\end{array}$ & 0 & 1 & 2 & 3 \\
\hline 6. I felt depressed & 0 & 1 & 2 & 3 \\
\hline 7. I feit that everything I did was an effort & 0 & 1 & 2 & 3 \\
\hline 8. I felt hopeful about the future & 0 & 1 & 2 & 3 \\
\hline 9. I thought my life had been a failure & 0 & 1 & 2 & 3 \\
\hline 10. I felt fearful & 0 & 1 & 2 & 3 \\
\hline 11. My sleep was restless & 0 & 1 & 2 & 3 \\
\hline 12. I was happy & 0 & 1 & 2 & 3 \\
\hline 13. I talked less than usual & 0 & 1 & 2 & 3 \\
\hline 14. I felt lonely & 0 & 1 & 2 & 3 \\
\hline 15. People were unfriendly & 0 & 1 & 2 & 3 \\
\hline 16. I enjoyed life & 0 & 1 & 2 & 3 \\
\hline 17. I had crying spells & 0 & 1 & 2 & 3 \\
\hline 18. I felt sad & 0 & 1 & 2 & 3 \\
\hline 19. I felt that people dislike me & 0 & 1 & 2 & 3 \\
\hline 20. I could not get "going" & 0 & 1 & 2 & 3 \\
\hline
\end{tabular}

20. I could not get "going"

Adapted from Radiff LS. The CES-D Scale: a self-report depression scale for tesearch in the genetal population. Appl Psychol Measurement 1977;1:387, Table 1. Copyright 1977 West Publishing Co/Applied Psychological Measurement Inc. Reproduced 
Appendix 17 - Center for Epidemiological Studies - Depression in Spanish 
Instrucciones para preguntas: Abajo hay una lista de las maneras en que usted se haya sentido o comportado. Por favor digame que amenudo usted se ha sentido de ésta forma durante la semana pasada.

Ocasionalmente

Raramente Alguno o o una cantidad

o ninguna pocotiempo moderada de

La mayoría

de las veces

tiempo

todo del

Durante la semana pasada

(menos de 1 dia) (1-2 dias)

(3-4 dias)

tiempo

1. Me molesté por cosas que usualmente no me molestan

2. No tenía ganas de comer, mi apetito fue pobre

3. Me sentí que no podía despejarme de mi mal estado de ánimo aún con la ayuda de mi familia 0 amigosias

4. Sentí que era tan bueno/a como otras personas

5. Tuve problemas manteniendo mi mente en lo que estaba haciendo

6. Me senti deprimido/a

7. Sentí que todo lo que hacia era un esfuerzo

8. Me sentí esperanzado hacia el futuro

9. Pensé que mi vida había sido un fracaso

10. Me sentí atemorizado

11. Mi sueño no tenía descanso

12. Estuve felíz

13. Hablé menos de lo usual

14. Me sentí solitario/solitaria

15. Las personas no eran amistosas

16. Disfruté la vida

17. Tuve períodos de llanto

18. Me sentí triste

19. Me sentí que no le caía bien a las personas

20. No podia "progresar/avanzar"

0

0

0

0

0

0

0

0

0

0

0

0

0

0

0

0

0

0 
Appendix 18 - State Trait Anxiety Form Y1 


\section{SELF-EVALUATION QUESTIONNAIRE}

Developed by Charles D. Spieiberger

in collaboration with

R. L. Gorsuch, R. Lushene, P. R. Vagg, and G. A. Jacobs

STAI Form Y-1

Name

Age Sex: MI

F

Date

S

T

DIRECTIONS: A number of statements which people have used to describe themselves are given below. Read each statement and then blacken in the appropriate circle to the right of the statement to indicate how you feel right now, that is, at this moment. There are no right or wrong answers. Do not spend too much time on any one statement but give the answer which seems to describe your present feelings best.

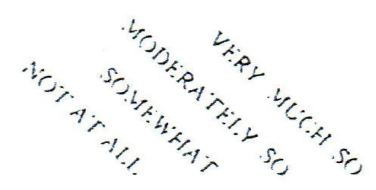

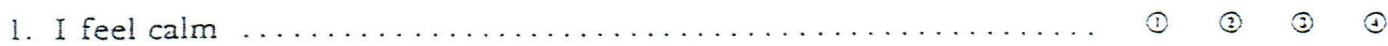

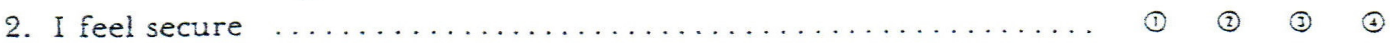

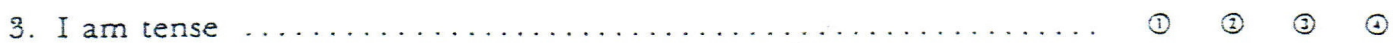

4. I feel strained $\ldots \ldots \ldots \ldots \ldots \ldots \ldots \ldots \ldots \ldots \ldots \ldots \ldots \ldots \ldots \ldots$ (3) (3) (3)

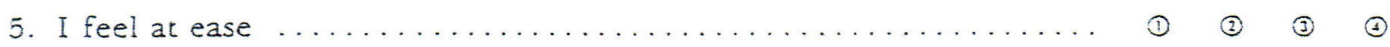

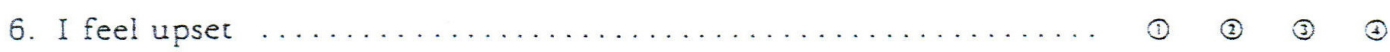

7. I am presently worrying over possible misfortunes $\ldots \ldots \ldots \ldots \ldots$ (3) (3) (3) (1)

8. I feel satisfied $\ldots \ldots \ldots \ldots \ldots \ldots \ldots \ldots \ldots \ldots \ldots \ldots \ldots \ldots \ldots \ldots \ldots$ (1) (2) (3)

9. I feel frightened $\ldots \ldots \ldots \ldots \ldots \ldots \ldots \ldots \ldots \ldots \ldots \ldots \ldots \ldots \ldots \ldots \ldots$ (1) (2) (1)

10. I feel comfortable $\ldots \ldots \ldots \ldots \ldots \ldots \ldots \ldots \ldots \ldots \ldots \ldots \ldots \ldots \ldots$ (2) (3) (3)

11. I feel self-confident $\ldots \ldots \ldots \ldots \ldots \ldots \ldots \ldots \ldots \ldots \ldots \ldots \ldots \ldots \ldots$ (1) (2) (1)

12. I feel nervous $\ldots \ldots \ldots \ldots \ldots \ldots \ldots \ldots \ldots \ldots \ldots \ldots \ldots \ldots \ldots$ (2) (3) (1)

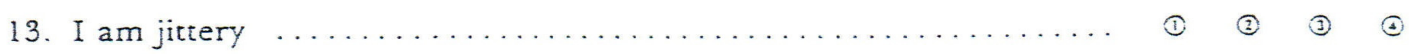

14. I feel indecisive $\ldots \ldots \ldots \ldots \ldots \ldots \ldots \ldots \ldots \ldots \ldots \ldots \ldots \ldots \ldots$ (3) (3) (3)

15. I am relaxed $\ldots \ldots \ldots \ldots \ldots \ldots \ldots \ldots \ldots \ldots \ldots \ldots \ldots \ldots \ldots \ldots \ldots$ (1) (3) (3)

16. I feel content $\ldots \ldots \ldots \ldots \ldots \ldots \ldots \ldots \ldots \ldots \ldots \ldots \ldots \ldots \ldots \ldots \ldots$ (1) (3) (3)

17. I am worried $\ldots \ldots \ldots \ldots \ldots \ldots \ldots \ldots \ldots \ldots \ldots \ldots \ldots \ldots \ldots$ (3) (3) (a)

18. I feel confused $\ldots \ldots \ldots \ldots \ldots \ldots \ldots \ldots \ldots \ldots \ldots \ldots \ldots \ldots \ldots \ldots$ (3) (3) (3) (3)

19. I feel steady $\ldots \ldots \ldots \ldots \ldots \ldots \ldots \ldots \ldots \ldots \ldots \ldots \ldots \ldots \ldots \ldots$ (3) (3) (1)

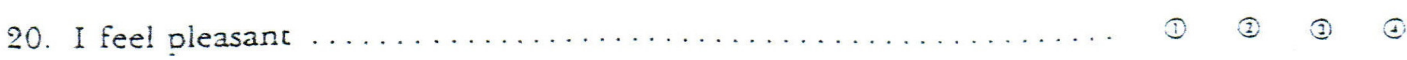

(2) Consulting Psychologists Press, Inc. 3803 E. Bayshore Road. Palo Alto, CA 94303 
Appendix 19 - State Trait Anxiety Form Y1 Spanish 


\title{
Questionario de Evaluación Propia
}

\author{
Creado por Charles D. Spielberger \\ en colaboración con
}

R. L. Gorsuch, R. Lushene, P. R. Vagg, and G. A. Jacobs

STAI Forma Y-1

Nombre

Edad

Sexo: $\mathrm{H}$

M

Fecha

S

$\mathrm{T}$

DIRECCIONES: Un número de declaraciones que las personas han usado para describirse a sí mismo están abajo. Lea cada declaración y despues llene el apropiado círculo a la derecha de la declaración para indicar como usted se siente ahora, es decir, en este momento. No hay respuestas correctas o incorrectas. No pierda mucho tiempo en ninguna de las declaraciones, pero dé la respuesta que parece decribir mejor sus sentimientos en este momento.

\begin{tabular}{|c|c|c|c|}
\hline $\begin{array}{l}\text { No Del Todo } \\
1\end{array}$ & $\begin{array}{l}\text { Algo } \\
2\end{array}$ & $\begin{array}{l}\text { Moderadamente } \\
3\end{array}$ & $\begin{array}{l}\text { Completamente Positivo } \\
4\end{array}$ \\
\hline 1. Me siento calmado/a $\ldots \ldots \ldots \ldots \ldots \ldots \ldots \ldots$ & 2 & 3 & 4 \\
\hline 2. Me siento seguro/a........................ & 2 & 3 & 4 \\
\hline 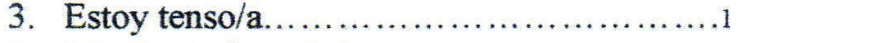 & 2 & 3 & 4 \\
\hline 4. Me siento forzado/a............................ & 2 & 3 & 4 \\
\hline 5. Me siento descansado $/$ a $\ldots \ldots \ldots \ldots \ldots \ldots \ldots \ldots \ldots \ldots \ldots$ & 2 & 3 & 4 \\
\hline 6. Me siento alterado $/ \mathbf{a} . \ldots \ldots \ldots \ldots \ldots \ldots \ldots \ldots \ldots \ldots \ldots \ldots \ldots$ & 2 & 3 & 4 \\
\hline 7. Estoy actualmente preocupado sobre & & & \\
\hline posible desgracias......................... & 2 & 3 & 4 \\
\hline 8. Me siento satisfecho/a...................... & 2 & 3 & 4 \\
\hline 9. Me siento asusutado/a..................... & 2 & 3 & 4 \\
\hline 10. Me siento cómodo ......................... & 2 & 3 & 4 \\
\hline 11. Me siento con confianza en mí mismo........1 & 2 & 3 & 4 \\
\hline 12. Me siento nervioso/a ........................... & 2 & 3 & 4 \\
\hline 13. Me siento tranquilo/a $\ldots \ldots \ldots \ldots \ldots \ldots \ldots \ldots$, & 2 & 3 & 4 \\
\hline 14. Me siento indeciso/a....................... & 2 & 3 & 4 \\
\hline 15. Estoy relajado/a............................ 1 & 2 & 3 & 4 \\
\hline 16. Estoy contento/a............................. & 2 & 3 & 4 \\
\hline 17. Estoy procupado/a........................... & 2 & 3 & 4 \\
\hline 18. Me siento confundido/a..................... 1 & 2 & 3 & 4 \\
\hline 19. Me siento estable.......................... 1 & 2 & 3 & 4 \\
\hline 20. Me siento complacido/a.. & 2 & 3 & 4 \\
\hline
\end{tabular}


Appendix 20 - State Trait Anxiety Form Y2 


\section{SELF-EVALUATION QUESTIONNAIRE}

STAI Form $Y-2$

Name Date

DIRECTIONS: A number of statements which people have used to describe themselves are given below. Read each statement and then blacken in the appropriate circle to the right of the statement to indicate how you generally feel. There are no right or wrong answers. Do not spend too much time on any one statement but give the answer which seems to describe how you generally feel.

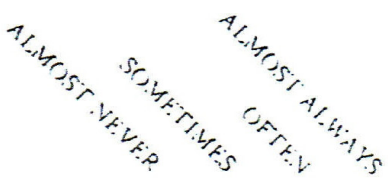

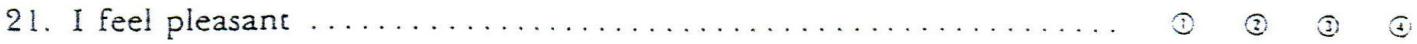

22. I feel nervous and restless $\ldots \ldots \ldots \ldots \ldots \ldots \ldots \ldots \ldots \ldots \ldots \ldots \ldots$ (1) (2) (3) (1)

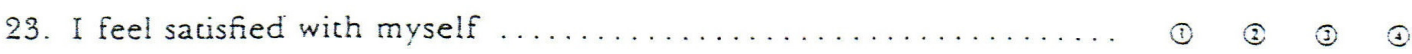

24. I wish I could be as happy as others seem to be ........... (1) (2) (3) (1)

25. I feel like a failure $\ldots \ldots \ldots \ldots \ldots \ldots \ldots \ldots \ldots \ldots \ldots \ldots \ldots \ldots \ldots \ldots \ldots \ldots \ldots$ (1) (2) (3) (1)

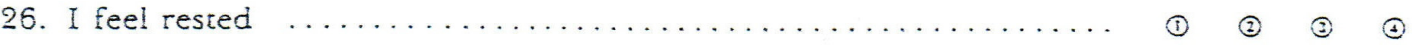

27. I am "calm, cool, and collected" ...................... (1) (3) (3) (3)

28. I feel that difficulties are piling up so that I cannot overcome them (1) (2) (3) (2)

29. I worry too much over something that really doesn't matter ..... (1) (2) (2) ()

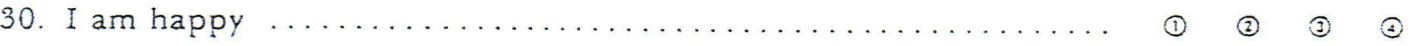

31. I have disturbing thoughts $\ldots \ldots \ldots \ldots \ldots \ldots \ldots \ldots \ldots \ldots \ldots \ldots \ldots \ldots$ (1) (2) (3) (1)

32. I lack self-confidence $\ldots \ldots \ldots \ldots \ldots \ldots \ldots \ldots \ldots \ldots \ldots \ldots \ldots \ldots \ldots$ (1) (2) (3) (1)

33. I feel secure $\ldots \ldots \ldots \ldots \ldots \ldots \ldots \ldots \ldots \ldots \ldots \ldots \ldots \ldots \ldots \ldots \ldots$ (1) (3) (3) (3)

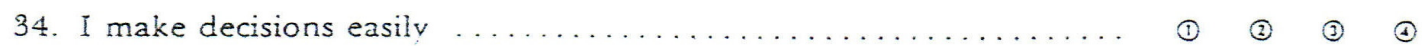

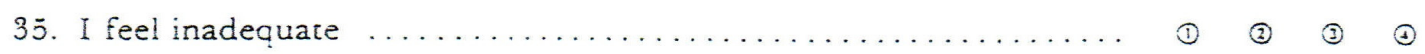

36. I am content ................................ (3) (3)

37. Some unimportant thought tuns through my mind and bothers me (2) (2) (3) (3)

38. I take disappointments so keenly that I can't put them out of my

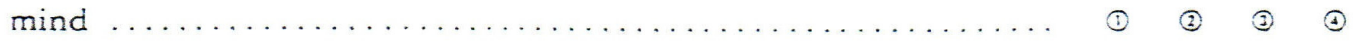

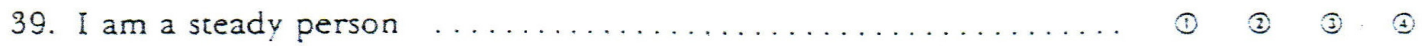

40. I get in a state of tension or turmoil as I think over my recent concerns and interests $\ldots \ldots \ldots \ldots \ldots \ldots \ldots \ldots \ldots \ldots \ldots \ldots \ldots \ldots \ldots \ldots$ (1) (2) (3)

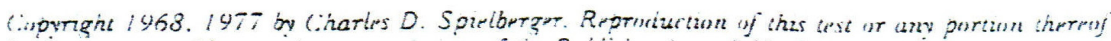
by any process without whaten permissuen of the Publisher is prianiouteti. 
Appendix 21 - State Trait Anxiety Form Y2 Spanish 


\section{Questionario de Evaluación Propia \\ STAI Forma Y-2}

Nombre

Fecha

DIRECCIONES: Un número de declaraciones que las personas han usado para describirse a sí mismo están abajo. Lea cada declaración y después llene el apropiado círculo a la derecha de la declaración para indicar como usted se siente generalmente. No hay respuestas correctas o incorrectas. No pierda mucho tiempo en ninguna de las declaraciones, pero dé la respuesta que parece decribir como usted generalmente se siente.

21. Me siento complacido/a..........................

22. Me siento nervioso y $\sin$ descanso $\ldots \ldots \ldots \ldots \ldots \ldots \ldots \ldots$

23. Me siento satisfecho/a de mí mismo/a................ 1

24. Yo desearía ser tan feliz como otros parecen ser........

25. Me siento como un fracaso ..........................

26. Me siento descansado/a............................

27. Yo estoy "calmado, sereno y seguro/a de mí mismo/a" 1

28. Siento que las dificultades se van amontonando y yo no puedo sobrepasarlas.............................

29. Me preocupo demasiado sobre algo que realmente

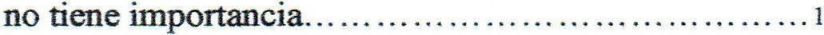

30. Estoy felíz

31. Tengo pensamientos que me perturban $\ldots \ldots \ldots \ldots \ldots \ldots 1$

32. Me falta confianza en mí mismo/a...................

33. Me siento seguro/a..............................

34. Tomo decisiones fácilmente $\ldots \ldots \ldots \ldots \ldots \ldots \ldots \ldots \ldots \ldots \ldots$

35. Me siento inadequado/a ...........................

36. Estoy contento/a....................................

37. Algunos pensamientos sin importancia pasan por mi mente y me molestan ..............................

38. Tomo los disgustos tan seriamente que no los puedo sacar de mi mente...............................

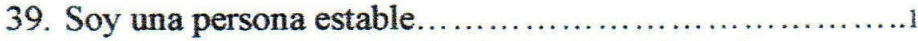

40. Me encuentro en un estado de tensión y desorden según pienso en mis recientes preocupaciones e intereses..........................................

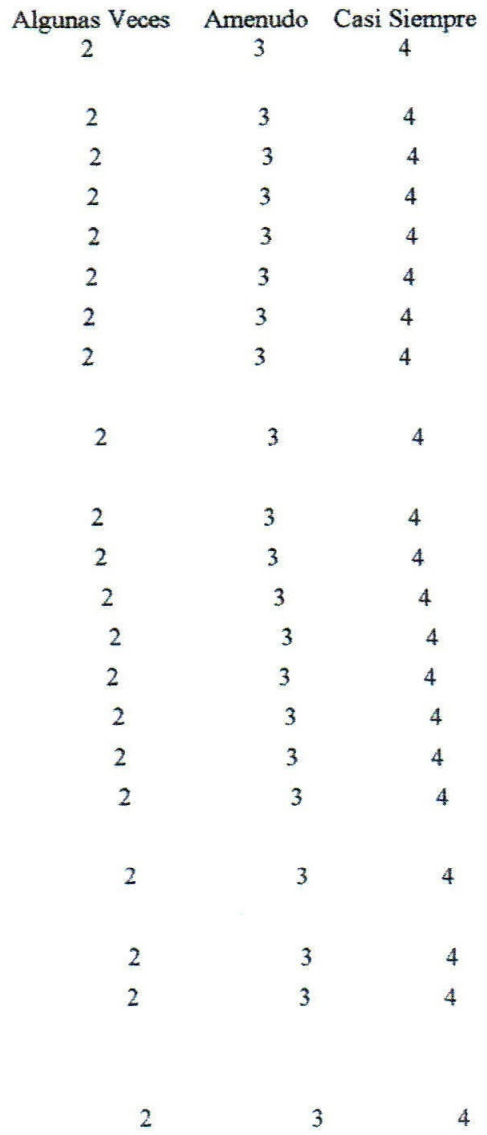


Appendix 22 - Debriefing Form 


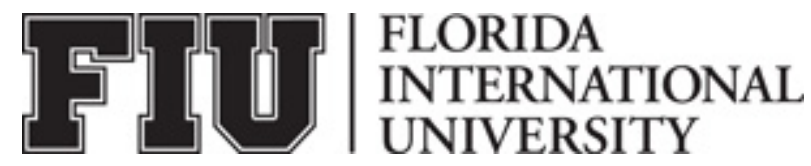

Debriefing Form

Thank you for participating in the present study which analyzes the interaction between demographics, caregiver burden, and coping styles in elderly caregivers. This study tests the linkages among demographic factors (such as age, gender, and ethnicity), perceived caregiver burden, coping with caregiving and their impact on life satisfaction.

Once again, you participation is greatly appreciated. If you know of anyone who is eligible for the present study, we ask that you do not discuss it with them until they have had a chance to participate as well. Any knowledge of the questions asked, prior to the interview, may change how a person responds. Thank you for your cooperation.

If you have any questions regarding this study, please feel free to ask the researcher at this time. You may also contact the researcher, Didiana De La Osa, by email at didiana.delaosa@yahoo.com or by phone at 305-878-9818. If you would like to talk with someone about your rights of being a subject in this research study or about ethical issues with this research study, you may contact the FIU Office of Research Integrity by phone at 305-348-2494 or by email at ori@fiu.edu.

If you would like to learn more about the topic of this research study, you may consult:

Hooker, K., Manoogian-O’Dell, M., Monahan, D. J., Frazier, L. D., \& Shifren, K. (2000). Does type of disease matter? Gender differences among Alzheimer's and Parkinson's disease spouse caregivers. The Gerontologist, 40(5), 568-573.

Raschick, M., \& Ingersoll-Dayton, B. (2004). The costs and rewards of caregiving among aging spouses and adult children. Family Relations, 53(3), 317-325. 
In the event that you feel psychologically distressed by participation in this study, we encourage you to call and schedule an appointment for psychological treatment at:

THE GOODMAN CENTER FOR PSYCHOLOGICAL SERVICES

2173 NW 99TH AVE

MIAMI, FL 33172

305-592-7860

NORTH MIAMI FOUNDATION FOR SENIOR CITIZENS

620 NE 127TH STREET

NORTH MIAMI, FL 33161

305-893-1450

JACKSON NORTH COMMUNITY MENTAL HEALTH CENTER

20201 N.W. 37TH AVENUE

MIAMI, FL 33056

786-466-2700 14701 N.W. 27TH AVENUE OPA-LOCKA, FL 33054

786-466-2700

CRISIS STABILIZATION UNIT (24-HOUR)

(786) 466-2834

ADULT CASE MANAGEMENT AND PSYCHOSOCIAL REHABILITATION SERVICES

(786) 466-1340 
Appendix 23 - Debriefing Form in Spanish 


\section{\begin{tabular}{l|l} 
FLORIDA \\
INTERNATIONAL \\
UNIVERSITY
\end{tabular}}

Gracias por participar en el estudio actual que analiza la relación entre factores demograficos, la sobrecarga del cuidador, y los estilos de manejar el ezfuerzo y tensión en cuidadores de ancianos. Este estudio pone a prueba los vínculos entre los factores demográficos (tales como edad, género y etnia), carga percibida del cuidador, y formas de hacerle frente a los cuidados y su impacto en la satisfacción con la vida.

De nuevo se le agradece su participación . Si usted sabe de alguien que es elegible para ste estudio, le pedimos que no lo hable con ellos sobre los questionarios hasta que hayan tenido la oportunidad de participar también. Conocimiento de las preguntas antes de la entrevista puede cambiar la forma en que una persona responde. Gracias por su cooperación.

Si usted tiene alguna pregunta relacionada con este estudio, por favor no dude en preguntar al investigador en este momento. También puede comunicarse con el investigador, Didiana De La Osa, por correo electrónico a didiana.delaosa@yahoo.com,o por teléfono al 305-878-9818. Si desea hablar con alguien acerca de sus derechos de ser un participante de este estudio de investigación o sobre los aspectos éticos con este estudio de investigación, puede comunicarse con la Oficina de Integridad de la Investigación de FIU por teléfono al 305-348-2494 o por correo electrónico a Ori @fiu.edu.

Si desea obtener más información sobre el tema de esta investigación, puede consultar:

Hooker, K., Manoogian-O’Dell, M., Monahan, D. J., Frazier, L. D., \& Shifren, K. (2000). Does type of disease matter? Gender differences among Alzheimer's and Parkinson's disease spouse caregivers. The Gerontologist, 40(5), 568-573.

Raschick, M., \& Ingersoll-Dayton, B. (2004). The costs and rewards of caregiving among aging spouses and adult children. Family Relations, 53(3), 317-325. 
En caso de que usted se siente psicológicamente angustiados por la participación en este estudio, le animamos a que llame y haga una cita para tratamiento psicológico en:

THE GOODMAN CENTER FOR PSYCHOLOGICAL SERVICES

2173 NW 99TH AVE

MIAMI, FL 33172

305-592-7860

NORTH MIAMI FOUNDATION FOR SENIOR CITIZENS

620 NE 127TH STREET

NORTH MIAMI, FL 33161

305-893-1450

JACKSON NORTH COMMUNITY MENTAL HEALTH CENTER 20201 N.W. 37TH AVENUE 14701 N.W. 27TH AVENUE

MIAMI, FL 33056 OPA-LOCKA, FL 33054

786-466-2700 $786-466-2700$

UNIDAD DE ESTABILIZACIÓN DE CRISIS (24-HORAS)

(786) 466-2834

MANEJO DE CASOS DE ADULTOS Y SERVICIOS DE REHABILITACIÓN PSICOSOCIAL

(786) 466-1340 